IDENTIFIKASI KANOPI POHON BERBASISECOLOGYCAL LANSCAPE DAN INDEX NATURALNESS SEBAGAI ECOSYSTEM SEERVICES TERHADAP KENYAMANAN PENGENDARA SEPEDA MOTOR DI PERSIMPANGAN JALAN KECAMATAN MATARAM

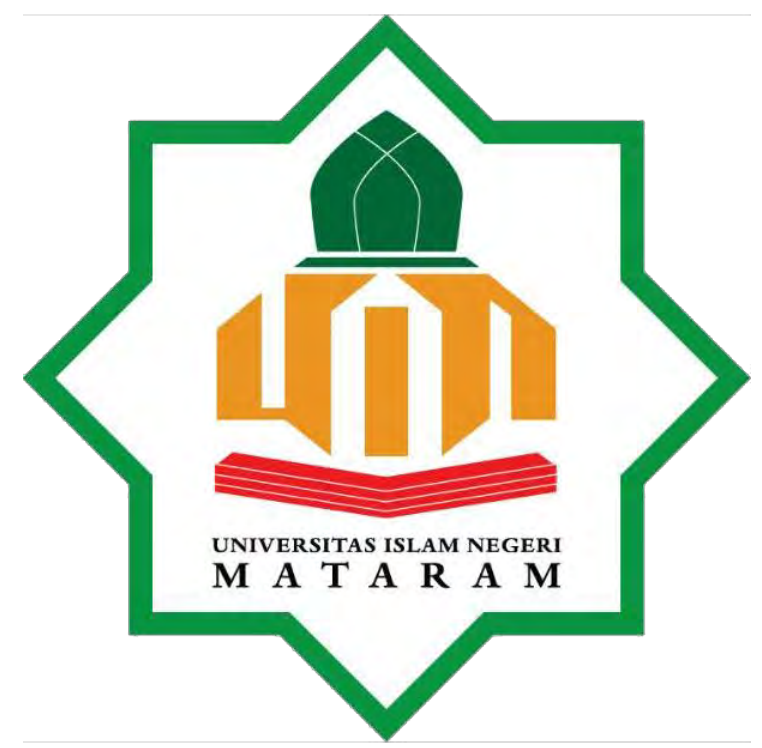

Oleh :

MUNIRI

15.1.14.5.091

JURUSAN PENDIDIKAN IPA BIOLOGI

FAKULTAS TARBIYAH DAN KEGURUAN (FTK)

UNIVERSITAS ISLAM NEGERI (UIN) MATARAM

MATARAM

2018 
IDENTIFIKASI KANOPI POHON BERBASISECOLOGYCAL LANSCAPE

DAN INDEX NATURALNESS SEBAGAI ECOSYSTEM SEERVICES

TERHADAP KENYAMANAN PENGENDARA SEPEDA MOTOR DI

PERSIMPANGAN JALAN KECAMATAN MATARAM

Skripsi

diajukan kepada Universitas Islam Negeri Mataram untuk melengkapi persyaratan mencapai gelar SarjanaPendidikan

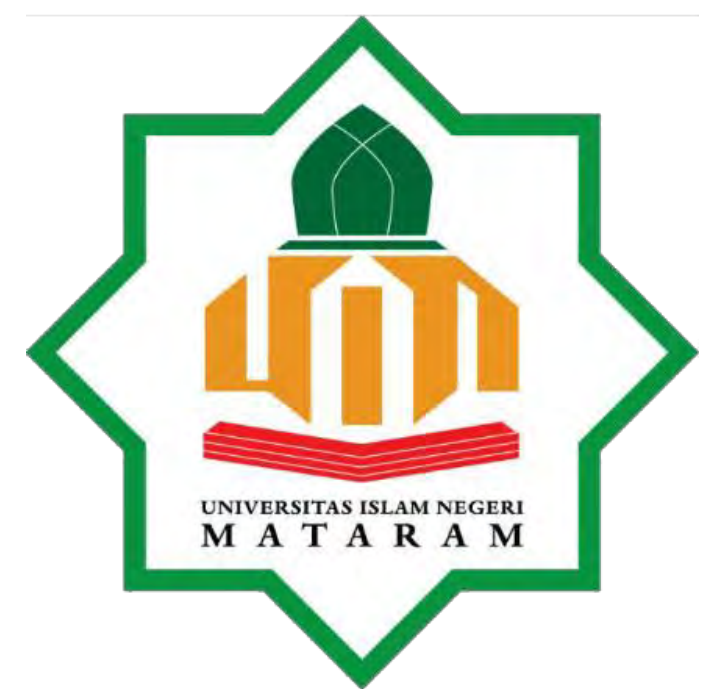

Oleh :

MUNIRI

15.1.14.5.091

JURUSAN PENDIDIKAN IPA BIOLOGI

FAKULTAS TARBIYAH DAN KEGURUAN (FTK)

UNIVERSITAS ISLAM NEGERI (UIN) MATARAM

MATARAM

2018 


\section{PERSLTLJUAN PEMBIMUING}

Shripst oleh Muniri, NIM: 151.145.091 dengan judul, "Identifikasi Kanopi Pohon Berbasis Ecologycal Lanscape dan Inder Naturalness Sebagai Ecosystem Secrices Terhadap Kenyamanan Pengendara Sepeda Motor di Persimpangan Jalan Vecanatan Mataram" telah memenuhi syarat dan disetujui untuk diuji

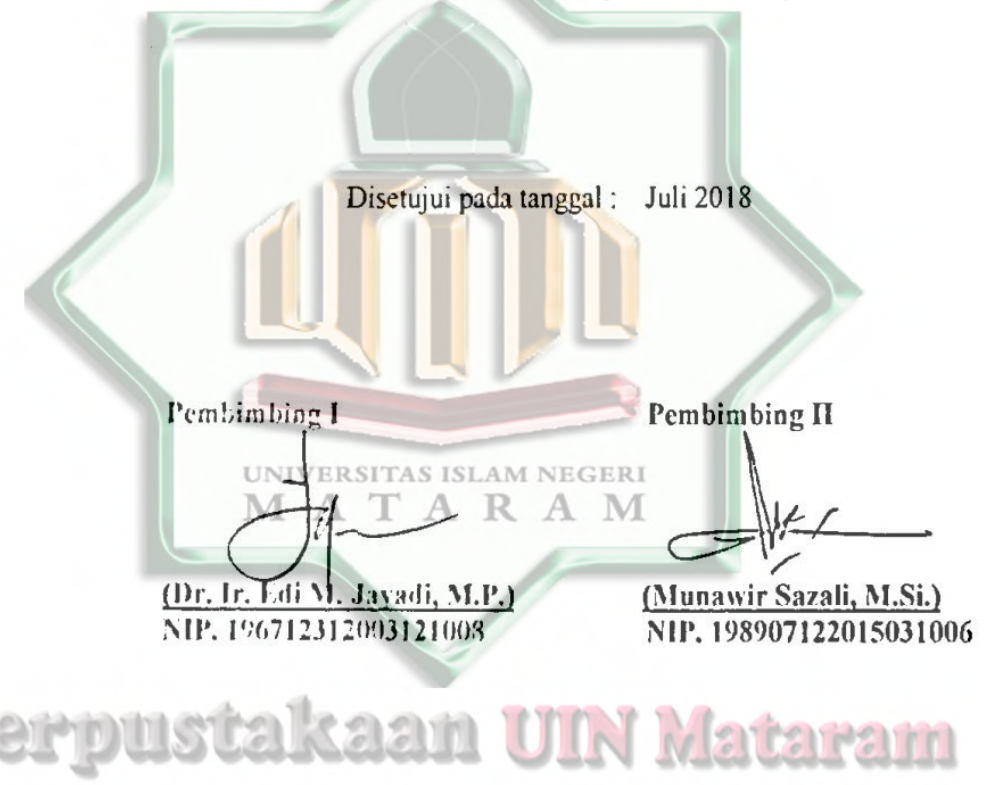

iii 


\section{Hal: Ujian Skripsi}

Mataram, Juli 2018

\section{Yang Terhormat}

\section{Rektor UIN Mataram}

\section{di Mataram}

Assalaamu'alaykum Warahmatullahi Wabarokaatuh

Disampaikan dengan hormat, setelah melakukan bimbingan, arahan, dan koreksi maka kami berpendapat bahwa skripsi saudara:

Nama Mahasiswa : Muniri

NIM

$: 151.145 .091$

Jurusan/Prodi : : Pendidikan IPA Biologi

Judul

: Identifikasi Kanopi Pohon Berbasis Ecologycal Lanscape dan Index Naturalness Sebagai Ecosystem Services Terhadap Kenyamanan Pengendara Sepeda Motor di Persimpangan Jalan Kecamatan Kota M A Mataram. A M

telah memenuhi syarat untuk diajukan dalam sidang munaqasyah skripsi Fakultas Tarbiyah dan Keguruan UIN Mataram. Oleh karena itu, kami berharap agar skripsi ini dapat segera dimunaqasyahkan.

Wassalaamu'alaykum Warahmatullahi Wabarokaatuh

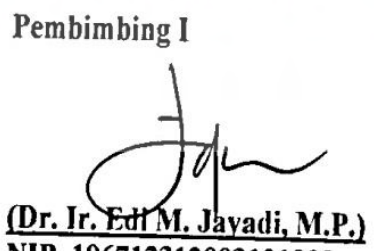

NIP. 196712312003121008

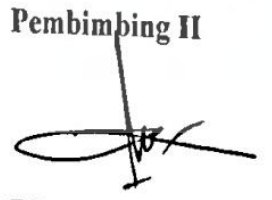

(Munawir Sazali, M.Si.) NIP. 198907122015031006 


\section{PENGESAIIAN DEWAN PENGUJI}

Shripsi oleh: Muniri, NIM: 151 145,091 dengan judul: Identifikasi Kanopi Pohon

Berbasis Ecologycal Lanscape dan Index Naturalness Sebagai Ecosystem Services

Terhadap Kenyamanan Pengendara Sepeda Motor di Persimpangan Jalan

Kecamatan Kota Mataram, telah dipertahankan di depan dewan penguji Jurusan

Tadris IPA Biologi Fakultas Tarbiyah dan Keguruan UIN Mataram pada tanggal

12 Juli tahun 2018.

Dr. Ir. Edi M. Jayadi. M.P

(Ketua Sidang/Pemb. I)

Munawir Sazali.M.Si.

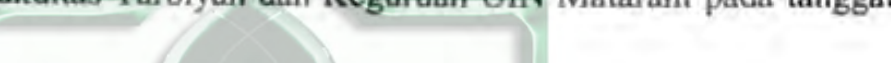

(Sekretaris Sidang/Pemb. 11)

Nurdiana, SP.MP.

(Penguji I)

Lutvia Krismavanti, M. Kes.

(Penguji II)

\section{Dewan Penguji}

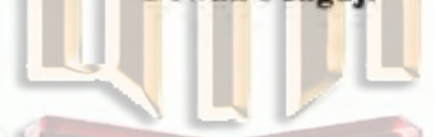

UNIVERSITAS ISLAM NEGER

$M A$ A R A M
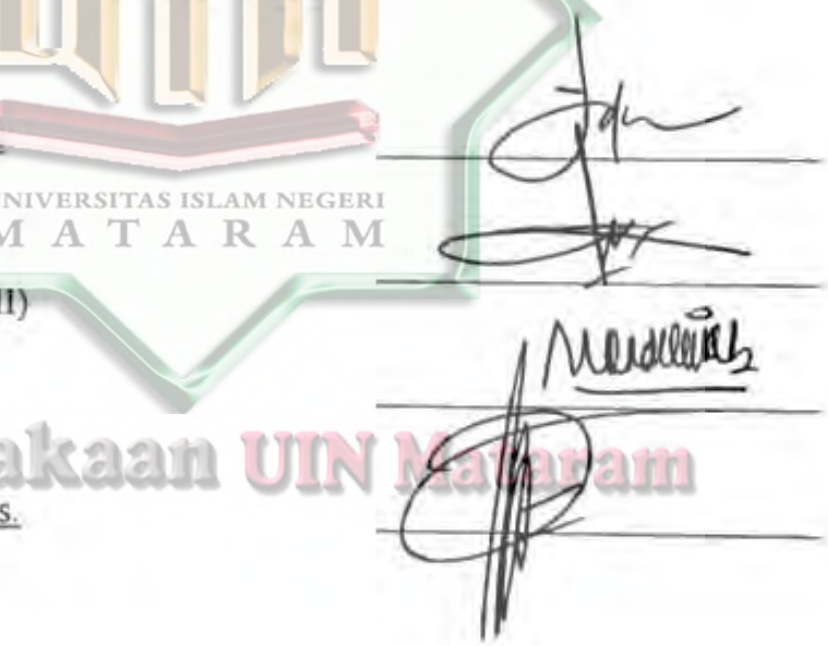

Mengetahui,

Dekan Fakultas Tarbiyah dan Keguruan

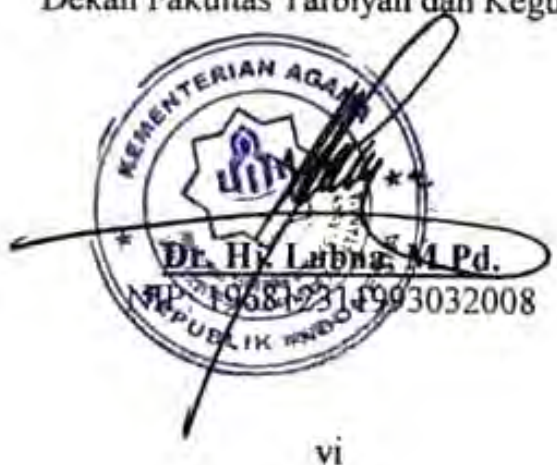




\section{MOTO}

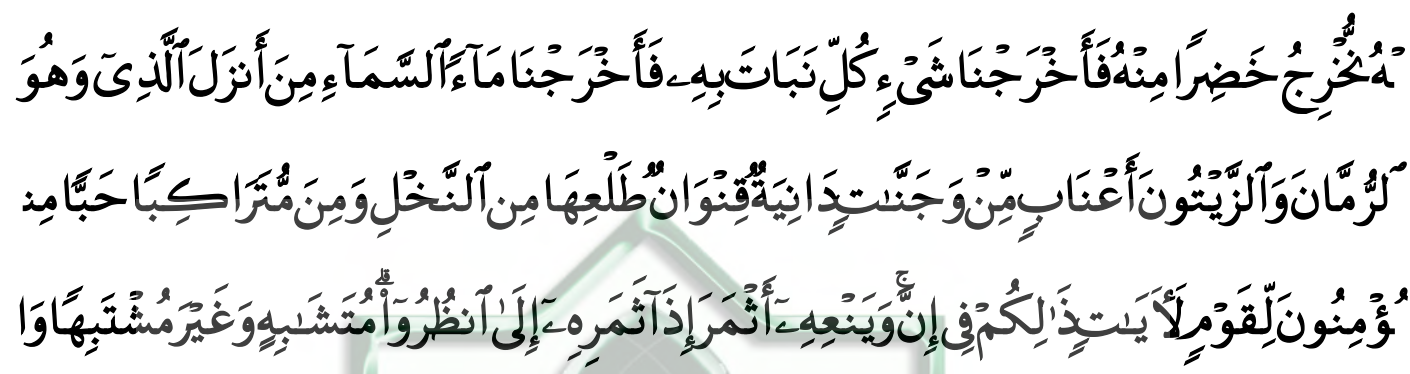

"Dan dialah yang menurunkan air hujan dari langit, lalu kami tumbuhkan dengan air itu segala macam tumbuh-tumbuhan Maka kami keluarkan dari tumbuh-tumbuhan itu tanaman yang menghijau. kami keluarkan dari tanaman yang menghijau itu butir yang banyak; dan dari mayang korma mengurai tangkai-tangkai yang menjulai, dan kebun-kebun anggur, dan (Kami keluarkan pula) zaitun dan delima yang serupa dan yang tidak serupa. perhatikanlah buahnya di waktu pohonnya berbuah dan (perhatikan pulalah) kematangannya. Sesungguhnya pada yang demikian itu ada tanda-tanda (kekuasaan Allah) bagi orang-orang yang beriman". '

${ }^{1}$ Kementrian Agama RI, Al-qur'an Tajwid Kode Transliterasi Per Kata Terjemah Per KataQs. Al-An'am ayat: 99. (Bekasi: Cipta Bagus Segara, 2013), hal.140. 


\section{PERSEMBAHAN}

\section{Bismillahirrahmanirrahim}

Beryukur kepada Allah Swt. dengan ucapan Alhamdulillah Hirrabbal Aalamin, dengan limpahan nikmat dan kemudahan yang diturunkan sehingga penulis dapat menyelesaikan skripsi ini. Sholawat dan salam senantiasa tercurahkan kepada kita sang penerbit cahaya dalam dunia yang fana yakni Nabi Muhammad Saw dengan penuh harapan kita mendapat safaat diakhirat kelak. Aamiin.

1. Skripsi ini saya persembahkan kepada kedua orang tua saya ( Indre dan Dinep ) dan seluruh keluarga besar yang telah memberikan pengajaran dan bimbingan dengan penuh kasih sayang hingga sampai saat ini tanpa sedikit mengeluh dan kata jenuh.

2. Seluruh guru-guru saya ( ${ }^{\mathrm{SDN}} \mathrm{S}_{4}$ Batunampar, SMPN 2 Jerowaru dan MAN 1 Praya) terimakasih yang tak terhingga atas ilmu yang telah diberikan.

3. Keluarga besar $\mathrm{CCS}^{\text {ee } 14}$ yang selalu menghadirkan pelangi di gelapnya kondisi dan keadaan. Terimakasih atas coretan sejarah yang telah kalian persembahkan dengan penuh harapan bisa terukir hingga masa depan.

4. Gerakan Pramuka Racana Khalid bin Walid-Siti Khadijah Pangkalan UIN Mataram yang telah menjadi Laboratorium terbesar dalam hidup saya hingga bisa mengecap indahnya dunia dalam bayangan tunas kelapa. 


\section{KATA PENGANTAR}

Puji syukur Alhamdulillah penulis panjatkan kehadirat Allah SWT yang telah melimpahkan taufiq dan hidayah-Nya, berkat rahmat dan petunjuknya, sehingga penulis dapat menyelesaikan skripsi ini. Sholawat serta salam semoga tetap tercurahkan kepada junjungan kita Nabi besar Muhamad SAW yang telah membawa petunjuk kebenaran seluruh umat manusia yaitu Agama Islam yang kita harapkan syafaatnya di Dunia dan di Akhirat.

Suatu kebahagiaan dan kebanggaan tersendiri bagi penulis karena dapat menyelesaikan skripsi ini. Penulis menyadari bahwa dalam menyelesaikan skripsi ini tidak lepas dari bimbingan dan arahan dari berbagai pihak. Oleh karena itu dengan segala kerendahan hati penulis ingin menyampaikan rasa hormat, ucapan terimakasih, serta penghargaan setinggi-tingginya kepada:

1. Bapak Dr Ir. Edi M Jayadi, M.P. selaku Dosen Pembimbing I dan Bapak Munawir Sazali, M.Si. selaku dosen pembimbing II yang telah memberikan bimbingan, motivasi, saran-saran, koreksi, dan arahan yang sangat bermanfaat sehingga skripsi ini bisa terselesaikan

2. Bapak Prof. Dr. H. Mutawali, M. Ag. selaku Rektor UIN Mataram, dan Ibu Dr. Hj. Lubna, M.Pd. selaku Dekan Fakultas dan Keguruan UIN Mataram yang telah memberikan kesempatan kepada penulis untuk menyelesaikan studi strata 1 di UIN Mataram.

3. Seluruh Dosen Jurusan Pendidikan IPA Biologi, Fakultas Tarbiyah dan Keguruan Universitas Islam Negeri (UIN) Mataram yang telah memberikan wawasan keilmuan selama menempuh program S1 ini. 
4. Seluruh staf Akademik FTK, yang senantiasa membantu dalam mendapatkan data-data yang diperlukan dalam penelitian ini.

5. Semua pihak yang ikut membantu penulis baik dalam hal moril, materil, ataupun spiritual, sehingga penulis dapat menyelesaikan skripsi ini.

Penulis menyadari bahwa penulisan skripsi ini masih jauh dari sempurna.

Oleh karena itu, saran dan kritik dari berbagai pihak sangat penulis harapkan. Sebagai ucapan terimakasih semoga bantuan yang telah diberikan mendapatkan balasan yang setimpal dari Allah. Penulis berharap semoga skripsi ini dapat bermanfaat bagi penulis dan pembaca.

Mataram, Juli 2018

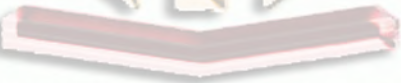

Penulis M A T A R A M

Penulis

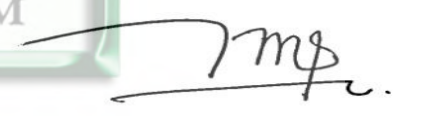

Muniri

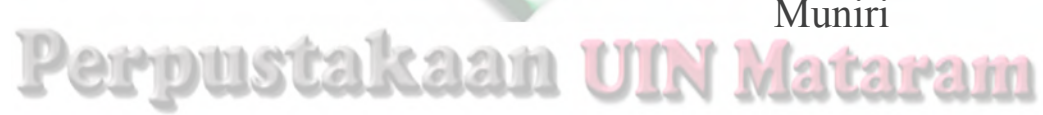




\section{DAFTAR ISI}

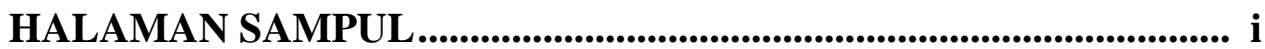

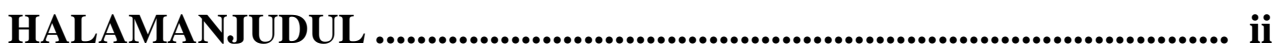

HALAMAN PERSETUJUAN .............................................................. iii

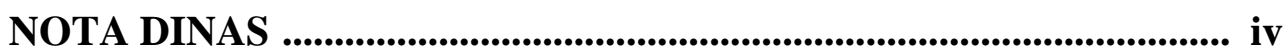

PERNYATAAN KEASLIAN SKRIPSI .................................................. vi

HALAMAN MOTO .................................................................................... vii

HALAMAN PERSEMBAHAN .................................................................. vii

KATA PENGANTAR .................................................................................. ix

DAFTAR ISI...................................................................................................

DAFTAR TABEL ................................................................................... xii

DAFTAR GAMBAR ...............................................................................

DAFTAR LAMPIRAN ................................................................................ xvi

ABSTRAK …......................................................................................................... xvii

BAB I PENDAHULUAN .............................................................................. 1

A. Latar Belakang Masalah ........................................................... 1

B. Rumusan Masalah .................................................................. 4

C. Tujuan dan Manfaat.............................................................. 4

D. Ruang Lingkup dan Setting Penelitian ....................................... 6

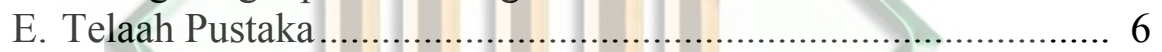

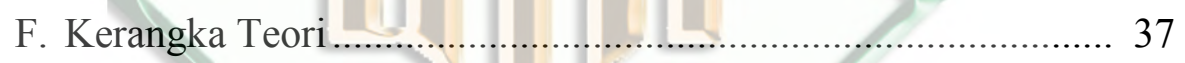

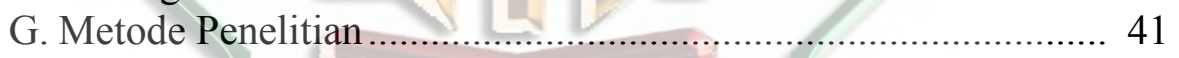

H. Sistematika Pembahasan ……................................................... 44

BAB IIPAPARAN DATA DANTEMUAN ............................................... 46

A. Gambaran Umum Lôkasi Penelitian. M...........................54

B. Peran Kanopi Pohon dan Index Naturalness .......................55

C. Kenyamaan Pengendara Sepeda Motor .........................86

BAB IIIPEMBAHASAN ............................................................................... 58

A. Peran Kanopi Pohon dan Index Naturalness.......................58

B. Peran Kanopi Pohon dan Index Naturalness .......................59

C. Solusi yang Peneliti Tawarkan ................................. 60

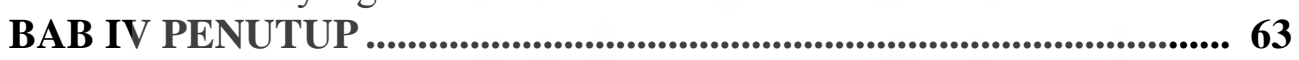

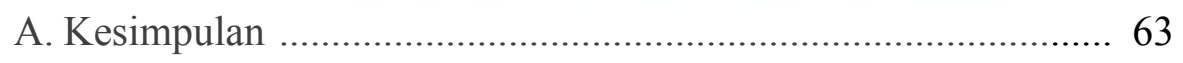

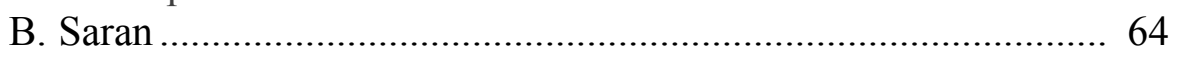

DAFATAR PUSTAKA .................................................................................... 65

LAMPIRAN-LAMPIRAN 


\section{DAFTAR TABEL}

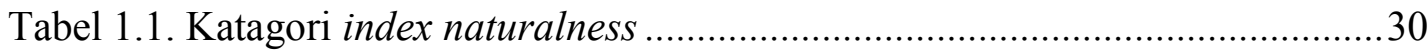

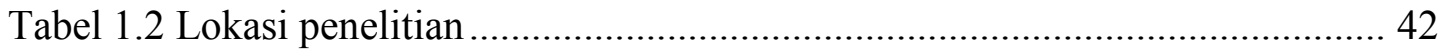

Tabel. 1.3 Aspek pembagian angket penelitian .................................................. 42

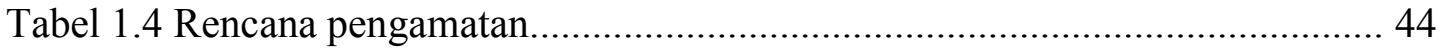

Tabel. 2.1 Index Naturalness dan LuasArea Persimpangan Gubnur ........................ 47

Tabel. 2.2 Index Naturalness dan LuasArea Persimpangan Kamboja ...................... 48

Tabel. 2.3 Index Naturalness dan LuasArea Persimpangan Sriwijaya .................... 49

Tabel. 2.4 Index Naturalness dan LuasArea Persimpangan Golkar ........................ 50

Tabel. 2.5 Index Naturalness dan LuasArea Persimpangan STMIK ........................ 51

Tabel. 2.6 Index Naturalness dan LuasArea Persimpangan Yaoya ......................... 52

Tabel. 2.7 Index Naturalness dan LuasArea Persimpangan Pagutan ....................... 53

Tabel 2. 1 Tingkat Kenyamanan Pengendara Sepeda Motor Dipersimpangan

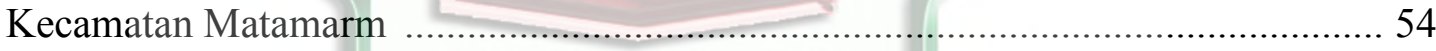

M A T A R A M 


\section{DAFTAR GAMBAR}

Gambar 1.1 Ecosystem service berupa kanopi pohon ......................................... 11

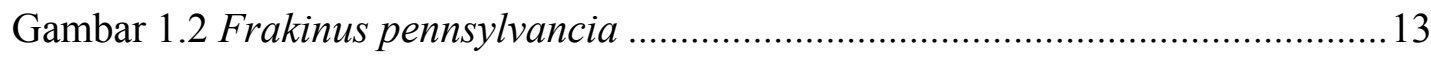

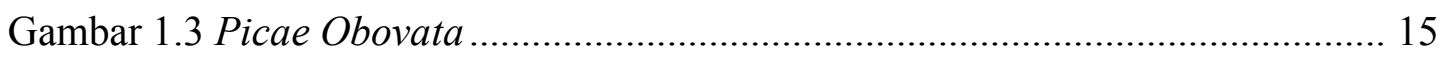

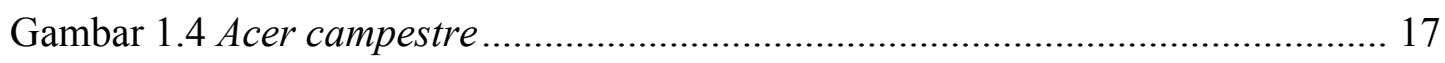

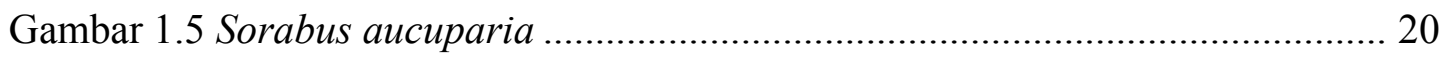

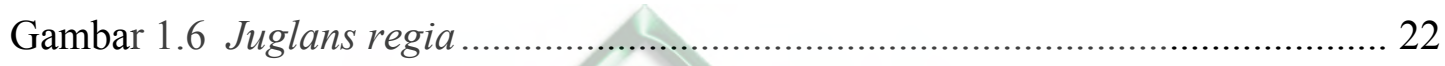

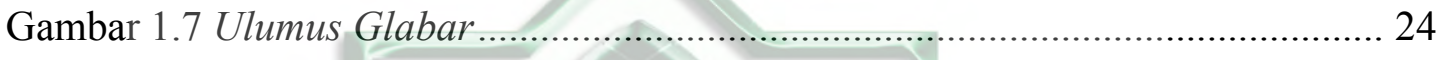

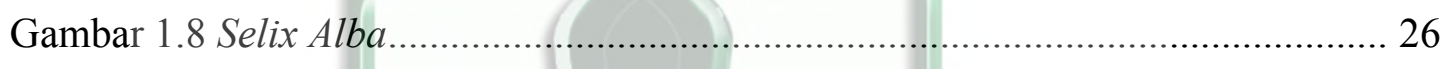

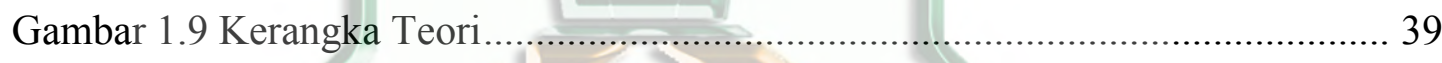

Gambar 1.10 Peta rencana wilayah pengamatan.................................................... 43

Gambar 2.1 Peta persimpangan kantor gubenur................................................. 47

Gambar 2.2 Peta persimpangan kamboja .................................................... 48

Gambar 2.3 Peta persimpangan stiwijya AM N..................................................... 49

Gambar 2.4 Peta persimpangan DPD Golkar ................................................... 50

Gambar 2.5 Peta persimpangan STMIK Gumi Gora ............................................. 51

Gambar 2.6 Peta pesimpangan Yaoya …........................................................... 52

Gambar 2.7 Peta persimpangan Pagutan.................................................................... 53 


\section{DAFTAR LAMPIRAN}

Lampiran I Lembar Kuisioner

Lampiran II Hasil Kuisioner

Lampiran III Dokumentasi Penelitian

Lampiran IV Surat-surat

Lampiran V kartu konsultasi

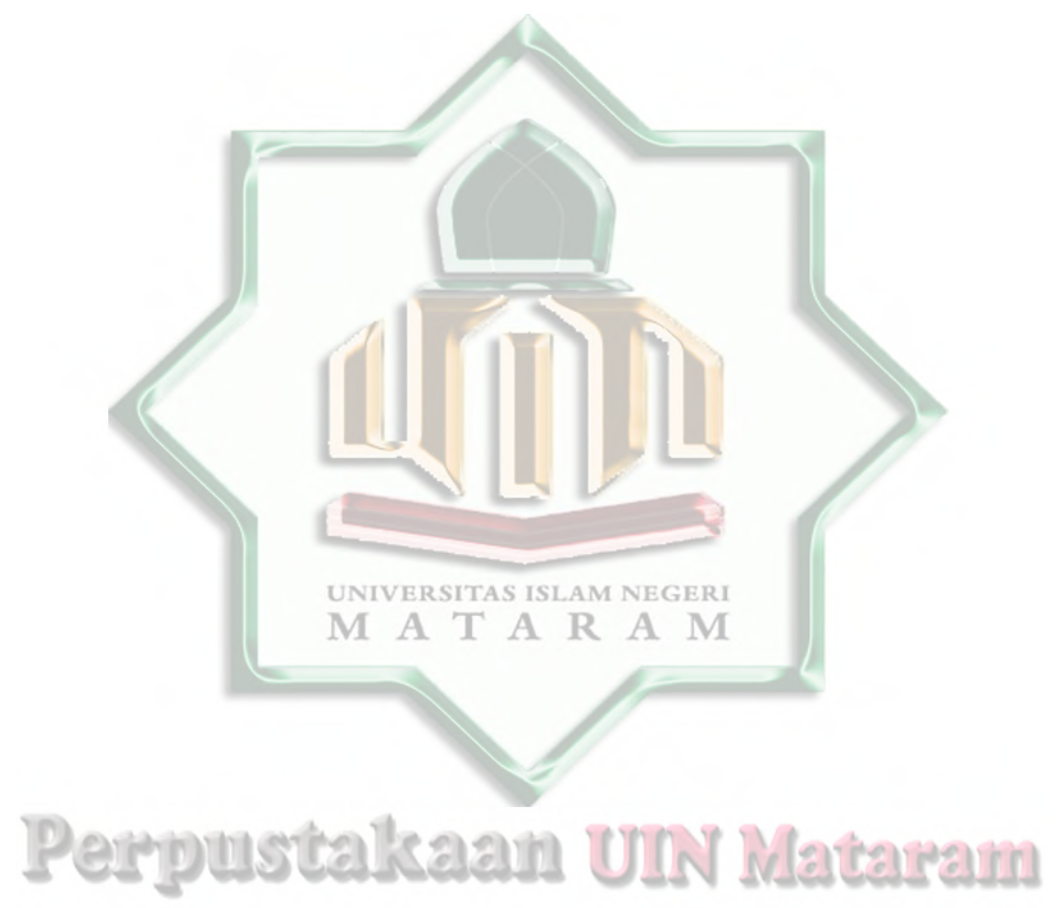




\title{
IdentifikasiKanopiPohonBerbasisEcologycalLanscapedanIndex
}

\author{
NaturalnessSebagaiEcosystem \\ SeervicesterhadapKenyamananPengendaraSepeda Motor di \\ PersimpanganJalanKecamatanMataram
}

Oleh :

MUNIRI

NIM. 151.145.091

\begin{abstract}
ABSTRAK
Pohon merupakan jenis tumbuhan berkayu yang mampu tumbuh besar dengan memanfaatkan hasil-hasil emisi buangan berupa karbon sebagai sumber pembentukan energi dan menghasilkan $\mathrm{O}_{2}$ melalui fotosintesis. Pohon juga bermanfaat sebagai naungan atau kanopi dari pancaran panas cahaya matarahari sehingga kanopi pohon memberikan rasa nyaman bagi manusia atau hewan dalam melakukan aktifitas disiang hari. Dimana penelitian ini bertujuan untuk mengetahui peran kanopi pohon berbasis ecologycalanscape dan index naturalness sebagai ecosystem seervices terhadap kenyamanan pengendara sepeda motor di persimpangan jalan Kecamatan Mataram pada Bulan Juni Tahun 2018. Jenis penelitian yang digunakan dalam penelitian ini adalah penelitian restrospektif (Ex post facto) dengan menggunakan pendekatan kualitatif. Populasi dalam penelitian ini adalah pohon yang terdapat di 7 pesimpangan jalan kecamatan Mataram yang memiliki lampu stop yaitu, persimpangan Gubnur, Kamboja, Sriwijaya, Golkar, STMIK, Yaoya dan Pagutan. Penelitian ini menggunakan sampel total karna yang diteliti yaitu seluruh pohon yang terdapat di 7 persimpangan jalan kecamatan Mataram. Variabel bebas yaitu peran kanopi pohon berbasis ecological landscape dan index naturalnesss ebagai ecosystem services dan variable terikatnya yaitu kenyamanan pengendara sepeda motor di persimpangan jalan Kecamatan Mataram. Dalam penelitian ini peneliti menggunak sofwer ArcGis. 10 untuk melakukan digitasi pemetaan dan pengekuran luas dengan dibantu oleh google eart untuk menentukan titik koordinat dari lokasi penelitian. Mengetahui tingkat kenyaman dari pengendara sepeda motor melalui kuiseoner yang disebar dengan 15 butir soal, dikatan nyaman ketika kreteria $70 \%$ dari total nilai soal yang ada. Sehingga dari hasil penelitian ini kita dapat mengetahui peran kanopi pohon berbasis ecological landscape terhadap kenyamanan pengendara sepeda motor di kecamatan Mataram.
\end{abstract}

Kata Kunci: Kanopi pohon, Ecologycal landscape dan Index Naturalness. 


\section{BAB I}

\section{PENDAHULUAN}

\section{A. Latar Belakang Masalah}

Kota Mataram sebagai ibu kota Nusa Tenggara Barat (NTB) terletak di Pulau Lombok. Kota ini merupakan pusat pengembangan di wilayah (NTB) pada umumnya dan berfungsi sebagai pusat pelayanan administrasi, jasa, pendidikan, dan perdagangan. Sebagaimana halnya kota-kota lain di Indonesia juga tak luput dari permasalahan-permasalahankota.

Kota Mataram yang terdiri dari 6 kecamatan diantaranya, Ampenan, Sekarbela, Mataram, Seleparang, Cakranegara, dan Sandubaya.Kota Mataram memiliki jumlah penduduk tahun 2016 tercatat 45.091 jiwa $/ \mathrm{km}^{2}$ dengan luas wilayah 6.130 Ha.Kecamatan mataram yang dijadikan sebagai lokasi penelitian yang memiliki tuas wilayah $1.076 \mathrm{Ha}$ dan jumlah penduduk 7.945 Jiwa (BPS-Statistics of Mataram City 2017).Pertumbuhan penduduk perkotaan yang semakin pesat tersebut beriringan dengan perkembanganperekonomian, pemukiman, pendidikan, dan budaya.Peningkatan jumlah penduduk perkotaan menimbulkan tekanan yang cukup besar terhadap sumberdaya dan lingkungan perkotaan. ${ }^{2}$

Salah satu peningkatan jumlah penduduk kota yang disebabkan oleh laju kelahiran dan gerak urbanisasi merupakan salah satu penyebab munculnya permasalahan di kota Mataram. Jumlah penduduk dan aktivitasnya seperti yang melibatkan kendaraan bermotor dan aktivitas lain

\footnotetext{
${ }^{2}$ Setyowati, D. L. 2008. Iklim Mikro dan Kebutuhan Ruang Terbuka Hijau di Kota Semarang.Jurnal Manusia dan Lingkungan, 15 (3): 125-140.
} 
juga menyumbang permasalahan suasana ketidaknyamanan kota. Hal ini membuat udara disekitar kota Mataram menjadi kotor oleh polutan kendaraan bermotor, yang dapat secara langsung berdampak terhadap keseimbangan lingkungan. ${ }^{3}$

Salah satu dampak dari perubahan lingkungan adalah berubahnya suhu.perubahansuhudiakibatkan oleh Ruang Terbuka Hijau (RTH) yang banyak mengalami alih fungsi menjadi bangunan-bangunan seperti perumahan, ruko dan lain-lain. Data stasiun klimatologi I kota Mataram pada tahun 2007 tercatat suhu udara tertinggi pada siang hari berkisar antara 23,40$31,40^{\circ} \mathrm{C}$, mengalami peningkatan pada tahun 2010 dengan suhu udara ratarata mencapai 23,91 sampai dengan $31,94^{\circ} \mathrm{C} .{ }^{4}$ Berdasarkan data $\mathrm{BMKG}$ Mataram rata-rata peningkatan suhu udara di kota Mataram selama 3 (tiga) tahun adalah 0,51 hingga $0,54^{\circ} \mathrm{C}$ hat ini diperkirakan karena jumlah sepeda motor yang semakin meningkat sehingga memberikan efekketidaknyamanan terutama bagi pengendara sepeda motor.

Currie dan Bass (2005), menjelaskan bahwa pohon dapat mereduksi polutan $\mathrm{CO}$ di udaralebih besar dibandingkan dengan rumput. Pohon merupakan jenis tumbuhan berkayu yang mampu tumbuh besar dengan memanfaatkan hasil-hasil emisi buangan berupa karbon sebagai sumber pembentukan energi dan menghasilkan $\mathrm{O}_{2}$ melalui fotosintesis. Selain itu, pohon juga bermanfaat sebagai naungan atau kanopi dari pancaran panas

\footnotetext{
${ }^{3}$ Humaidi, M. Artikrl Pohon Pelindung Jalan di Kotamadya Mataram (skripsi FKIP: UNRAM, 2003) hal. 01

${ }^{4}$ Bapeda dan BPS Kota Mataram. 2012. Mataram dalam Angka Tahun 2012. Mataram. BPS KotaMataram. Hal. 04.
} 
cahaya matarahari sehingga kanopi pohon memberikan rasa nyaman bagi manusia atau hewan dalam melakukan aktivitas disiang hari. ${ }^{5}$

Keberadaan kanopi pohon di Kota Mataram khususnya pada jalur taransportasi sangat kurang terutama pada persimpangan jalan. Hal ini yang membuat pengendara sepeda motor merasa kurang nyaman. Salah satu teknik untuk melakukan pemetaan dalam penelitian yaitu bisa menggunakan sofwer ArcGIS, yaitu salah satu sofwer yang dikembangkan oleh ERCI (Environment Science \& Reaseach Institute) yang merupakan kompilasi fungsi-fungsi salah satunya yaitu digunakan untuk mengolah, membuat, menampilkan, memilih, dan mengedit sebuah peta.Penelitian yang dilakukan oleh prasetio, dkk (2006) yang terkait tentang studi diskripsi hubungan antara naturalness index dan Biodiversity Indek dengan iklim mikro berbasis Ecilogical Landscape. Peneliti menggunkan fasilitas google map dan GPS dalam pengambilan sampel. ${ }^{6}$

Dengan penggunaan sofwer ArcGIS akandapat diketahui titik-titik koordinat pesimpangan jalan yang ada di kecamatan mataram dan kita akan mampu membandingkan tingkan kealamiannya (index naturalnees) dengan melihat dari peta yang kita buat. Konsep naturalness (kealamian) dideskripsikan sebagai suatu nilai konservasi dan deskriptor pada suatu wilayah.Ranking naturalness index dikategorikan pada rentang nilai

${ }^{5}$ Michael Oloyede Alabi dan Enete Ifeanyi Christian. 2013. Street Tree Canopy Cover Variation Effects on Temperature in Lokoja, Nigeria. Journal of Agriculture and Environmental Sciences, Vol. 2 No. 2. Hal. 25-31.

${ }^{6}$ Prastiyo, dkk. 2016. Studi deskripsi hubungan antara naturalness index dan biodiversity index dengan iklim mikro padaKelurahan jatimulyo, mojolangu,dan mergosono di kota malangberbasis ecological landscape. Vol. 9, Hal. 274-285. 
maksimum 10 untuk sistem alami absolut hingga nilai minimum (0) untuk sistem buatan absolut (Machado, 2004). ${ }^{7}$ data yang didapatkan akan dikaitkan dengan tingkat kenyamanan warga sehingga kita akan mengetahui bagaimana kanopi pohon memberikan pelayanan secara langsung atau tidak langsung berupa kontribusi untuk meningkatkan kesejahtraan manusia.

\section{B. Rumusan Masalah}

Berdasarkan uraian latar belakang di atas, maka diajukan rumusan masalah sebagai berikut : bagaimanakah peran kanopi pohon berbasis ecologycal lanscape dan index naturalness sebagai ecosystem seervices terhadap kenyamanan pengendara sepeda motor di persimpangan jalan Kecamatan Mataram tahun 2018?

\section{Tujuan dan Manfaat}

1. Tujuan

Tujuan penelitian ini adalahuntuk mengetahui peran kanopi pohon berbasis ecologycal lanscape dan index naturalnesssebagai ecosystem seervices terhadap kenyamanan pengendara sepeda motor di persimpangan jalan Kecamatan Matarampada Bulan Juni Tahun 2018.

\section{Manfaat}

\section{a. Manfaat Teoritis}

Melalui penelitian ini diharapkan dapat meningkatkan pengetahuan dan wawasan pembaca terkaitkanopi pohon berbasis ecologycal lanscape dan index naturalness sebagai ecosystem

\footnotetext{
${ }^{7}$ Machado, A. 2004.An Index of Naturalness.Journal of Nature Conservation, 12, 95-110.
} 
seervices terhadap kenyamanan pengendara sepeda motor di persimpangan jalan Kecamatan Mataram.

\section{b. Manfaat Praktis}

1) Bagi peneliti

Untuk memperoleh informasi yang jelas mengenaikanopi pohon berbasis ecologycal lanscape dan index naturalness sebagai ecosystem seervices terhadap kenyamanan pengendara sepeda motor di persimpangan jalan Kecamatan Mataram.

2) Masyarakat

Untuk menambah pengetahuan kepada masyarakat bahwa dengan hadirnya kanopi pada wilayah persimpangan jalan yang disatu sisi sebagai tempat berteduh para pengendara motor dan disisi lain sebagai penyedia oksigen yang merupakan kabutuhan utama makhluk hidup.

\section{3) Pemerintah}

Sebagai referensi instansi Tata Kota Mataram dalam menciptakan ruang kota yang bebas polusi serta kenyaman para pengguna jalan.

\section{Ruang Lingkup dan Setting Penelitian}

\section{Ruang lingkup}

Dalam sebuah penelitian diperlukannya batasan-batasan terhadap pokok permasalan dalam pembahasan, sehingga apa yang menjadi fokus dari kajian peneliti benar-bener terarah dan tidak terlalu meluas.Adapun 
yang menjadi fokus penelitian yang dikaji dalam pembahasan ini adalah bagaimanamengetahui peran kanopi pohon berbasis ecologycal lanscape dan index naturalnesssebagai ecosystem seervices terhadap kenyamanan pengendara sepeda motor di persimpangan jalan Kecamatan Mataram.

\section{Setting penelitian}

Penelitiantentang identifikasi kanopi pohon berbasis Ecologycal landscape dan Index Naturalness sebagai Ecosystem Seervices ini dilakukan di 7 persimpangan jalan yang berada di kecamatan Mataram. Pemetaan wilayah dilakukan dengan menggunakan sofwer ArcGIS yang sesui dengan tingkat kealamian wilayah (index naturalness).

\section{E. Telaah Pustaka}

\section{Tinjauan Pustaka}

a. Pohon

UNIVERSITAS ISLAM NEGER

1) Definisi pohon

Pohon merupakan tumbuhan berkayu yang memiliki satu batang utama (trunk) dan sedikitnya memiliki satu atau beberapa dahan (branches). Pohon memiliki perbedaan dengan semak (shrub) yaitu memiliki ukuran kurang dari 5 meter dan sebagian besar memiliki cabang yang banyak dekat batang utamanya, sedangkan pohon memilki percabangan utama stelah memiliki ukuran kurang lebih 3 meter. $^{8}$

2) Fungsi pohon

${ }^{8}$ Wahyunah, dkk. Variasi kanopi dan prositas pohon di ruang hijau pribadi permukiman baru di kelurahan loktabat utara kota banjarbaru. Jukung jurnal teknik lingkungan 2(2) 2016. Hlm: 62 . 
Keberadaan pepohonan yang dikelola dengan baik di perkotaan dapat bermanfaat menstabilkan kondisi lingkungan perkotaan dari polusi. Peranan pohon di lingkungan perkotaan yaitu, meningkatkan kualitas udara, peredam kebisingan, menurunkan suhukota, memperindah kota, pelestarian air tanah, meningkatkan keselamatan berlalu lintas, dan mendukung keberhasilan ekonomi. ${ }^{9}$

\section{b. Kanopi}

\section{1) Pengertian kanopi Pohon}

Kanopi pohon diambil dari istilah tree canopy yang sudah banyak dikaji dalam ilmu lingkungan untuk melihat fungsi dan penerapannya. Kanopi pohon (tree canopy) merupakan lapisan dari dedaunan, cabang dan batang dari pepohonan yang menutupi permukaan tanah ketika dilihat dari bagian atas. Selain itu kanopi pohon merupakan bagian dari tumbuhan yang mampu menutupi bagian permukaan tanah dari cahaya matahari. Kanopi pohon menyediakan berbagai manfaat untuk kebutuhan manusia, diantaranya: meningkatkan kualitas air, menyimpan energi, mengurangi paparan cahaya matahari, mereduksi polusi udara, meningkatkan nilai estetika lingkungan, meyediakan habitat bagi

\footnotetext{
${ }^{9}$ Ekindo Vanesah Sitinjak. "Status Kesehatan Pohon Pada Jalur Hijau Dan HalamanParkir
} Universitas Lampung". (skripsi, fakultas pertanian,Univeritas lampung, bandar lampung, 2016) HIm: 6-9. 
organisme lain dan memfasitlitasi peluang pembelajaran dan kehidupan social. ${ }^{10}$

Kanopi merupakan kata lain dari tempat teduh. Kanopi merupakan latar yang meyajikan kanopi pohon berupa tumbuhan yakni pepohonan yang berwarna hijau, namun adapula istilah noncanopy yang berarti penutupan lahan selain dari kanopi pohon seperti bagunan, badan air dan lahan terbuka. ${ }^{11}$ Ketepatan model kanopi untuk mereduksiefek dari aerodynamic dapat menggunakan pengujian CFD dari kecepatan angin dalam ranah atau ruang lingkup pejalan kaki. Penanaman tumbuhan merupakan salah satu tindakan untuk menciptakan ruang hijau kota. Kanopi juga dikatakan sebagai sebuah pelayanan ekosistem atau ecosystem service yang berarti memberikan manfaat bagi manusia yang dapat berupa tanah, air, vegetasi dan atmosfer yang akan memberikan pelayanan seperti air bersih, air minum dan makanan.

Kanopi pada umumnya tidak hanya berupa pohon atau tumbuhan lainnya. Kanopi dapat berupa bangunan tinggi, atap rumah, bagasi mobil dan lain-lain dan biasanya dikelompokkan ke dalam kanopi sintesis atau buatan yang hanya memberi pelayanan ekosistem berupa tempat teduh dan bisa pula sebagai penataan

\footnotetext{
${ }^{10}$ National Researcher Council. A Report on Existing and Possible Tree Canopy in the City of Charlotte and Mecklenburg County, NC. Washington, DC: The National Academies Press.2014.

${ }^{11}$ Lumanniah, Purwanti. Manfaat Kanopi Pohon Dalam Upaya Penyimpanan Dan Penyerapan Karbon Di Kawasan Permahan Kota Bogor. (Skripsi, Fakultas Pertanian Institut Pertanian Bogor, 2011).
} 
ruang. Lain halnya dengan kanopi alami selain yang disebutkan sebelumnya, dapat pula mengurangi temperatur udara melalui siklus hidrologi dengan cara memperbanyak kecepatan angin. ${ }^{12}$ Sehingga dengan hadirnya kanopi di persimpangan jalan, selain para pengendara mendapatkan kenyamanan dalam berkendaraan, polusi yang disebabkan oleh kendaraan dapat diperkecil dengan mengasimilasi gas buang kendaraan bermotor serta membentuk keseimbangan ekosistem.

Kehadiran kanopi sebagai layanan ekosistem ini dapat dijadikan sebagai solusi untuk mengurangi tingkat pelanggaran kendaraan bermotor. Sebagaimana disebutkan dalam sebuah penelitian di Kota Bogor mengenai kanopi sebagai layanan ekosistem berupa asimilasi CO di daerah perkotaan. Sebagaimana pula yang kita ketahui bahwa tumbuhan tingkat tinggi sampai tungkat rendah memiliki potensi menghasilkan $\mathrm{O}_{2}$ dari bahan dasar $\mathrm{CO}_{2}$, sehingga dengan hadirnya kanopi berupa pohon selain dapat menurunkan pelanggaran dapat pula menurunkan polusi udara yang disebabkan oleh kendaraan bermotor dan diperkuat lagi oleh data dari Badan Pusat Statistik Kota Bogor bahwasanya polusi pada tahun 2012 megalami kenaikan sebanyak 3,87\% dari tahun

\footnotetext{
${ }^{12}$ Loughhner P, Chistopher. Roles of Urban Tree Canopy and Buildings in Urban Heat Island Effect: Parameterization and Preliminary Result. (Manuscript, Departement of Atmospheric and Oceanic Science, University of Myrland, Collage Park, Myrlad, 2011)
} 
sebelumnya dna berbanig lurus dengan jumlah kendaraan di Kota Bogor sebanyak 3,61\%. ${ }^{13}$

Sebuah studi literratur mengakatakan bahwa dengan hadirnya kanopi dapat memberi tata ruang kota yang indah, sehingga dapat dinikmati oleh semua orang dan bukan hanya oleh para pengendara bermotor. Bahkan bisa menjamin orang disekitarnya akan menghabiskan waktunya di luar rumah sambil menikmati pemandangan kanopi yang ada. Sehingga bisa dijamin dnegan hadirnya kanopi pohon dapat mengurangi tingkat kriminalitas bersamaan dengan meningkatnya masyarkat yang memilih berkegiatan di luar rumah. Lain halnya ketika para kriminal melihat kondisi lingkugan yang sepi karena UNIVERSITAS ISLAM NEGERI

masyarakatnya yang memilih untuk diam dirumah, karena sebuah tindakan kriminal biasanya terjadi ketika ada sebuah peluang untuk melakukannya. $^{14}$

\footnotetext{
${ }^{13} \mathrm{R}$ Covey, Kevin, dkk. Study of the Effectivity of Several Types on Roadside Green Belt in Influencing, The Distribution Vertically and Horizontally of $\mathrm{CO}$ gas Emitted from Transpiration Activities to Vicinity of The Road. Earth and Enviromental Science. 2016..

${ }^{14}$ Troy, Austin, dkk. The relationship between tree canopy and crime rates across an urban-ruralgradient in the greater Baltimore region. Landscape adn Urban Planning : Unites state.2012.
} 


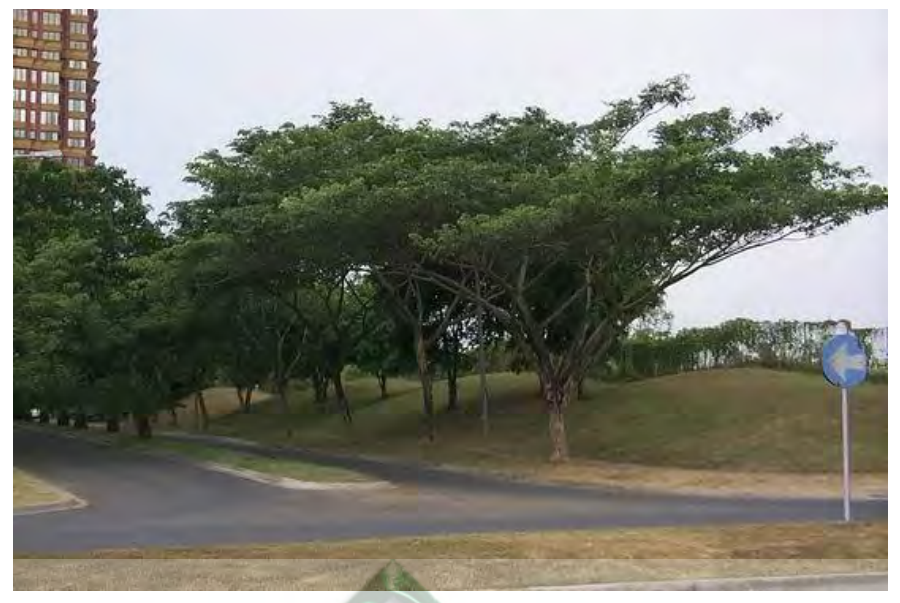

Gambar 1.1 Ecosystem service berupa kanopi pohon

Pohon merupakan jenis tumbuhan berkayu yang mampu tumbuh besar dengan memanfaatkan hasil-hasil emisi buangan berupa karbon sebagai sumber pembentukan energi dan menghasilkan $\mathrm{O}_{2}$ melalui fotosintesis. Selain itu, pohon juga bermanfaat sebagai naungan atau kanopi dari pancara panas cahaya matarahari sehingga kanopi pohon memberikan rasa nyaman bagi manusia atau hewan dalam melakukan aktifitas disiang hari. ${ }^{15}$

Ecosystem service berupa kanopi pohon merupakan bentuk salah satu pelayanan lingkungan yang diberikan oleh tumbuhan yakni pohon. Dengan adanya kanopi berupa pohon, suhu disekitar menjadi lebih baik dan para pengendara bermotor lebih nyaman sehingga peluang terjadinya pelanggaran traffic light dapat berkurang.

${ }^{15}$ Michael Oloyede Alabi dan Enete Ifeanyi Christian. 2013. Street Tree Canopy Cover Variation Effects on Temperature in Lokoja, Nigeria. Journal of Agriculture and Environmental Sciences, Vol. 2 No. 2. Hal. 25-31. 


\section{2) Bentuk Kanopi Pohon}

\section{a. Columnar}

1) Tinggi $15-20$ '

Pengelompokkan columnar yang pertama dilihat dari tinggi pohon yang berkisar $15-20 \mathrm{~cm}$.

a) Nama Botani

Adapun nama botani tumbuhan dengan tekstur columnar adalah Amelanchier x 'Robin Hill'

b) Nama Umum

Adapun nama umum tumbuhan dengan tekstur columnar adalahRobin Hill Serviceberry $x \quad I$. cornutaolehNellie R. Stevens Holly

UNIVERSITAS ISLAM NEGER I

2) Tinggi $20-45^{\prime} T A R$ A M

Pengelompokkan columnar yang pertama dilihat dari tinggi pohon yang berkisar $20-45 \mathrm{~cm}$.

a) Nama botani

Adapun nama botani tumbuhan dengan tekstur columnar yaitu :Acer platanoides „Columnar", Acer x Freemani „Armstrong ${ }^{e e}$, Acer rubrum „Bowhall“e

b) Nama Umum

Adapun nama umum dan dikenal khalayak umum tumbuhan dengan tekstur columnar adalah Columnar 
Norway Maple, Armstrong Red Maple dan Bowhall Red Maple.

3) Tinggi $>45$

Pengelompokkan columnar yang ketiga dilihat dari tinggi pohon yang berkisar lebih dari $45 \mathrm{~cm}$.

a) Nama Botani

Adapun nama botani tumbuhan dengan tekstur columnar dengan tinggi lebih dari $45 \mathrm{~cm} * \mathrm{X}$ Cupressocyparis leylandiidanQuercus robur fastigiata

b) Nama umum

Adapun nama umum dan dikenal khalayak umum tumbuhan dengan tekstur columnar adalahLeyland Cypress UNIVERSITAS ISI AM NEGERI dan Skyrocket English Oak

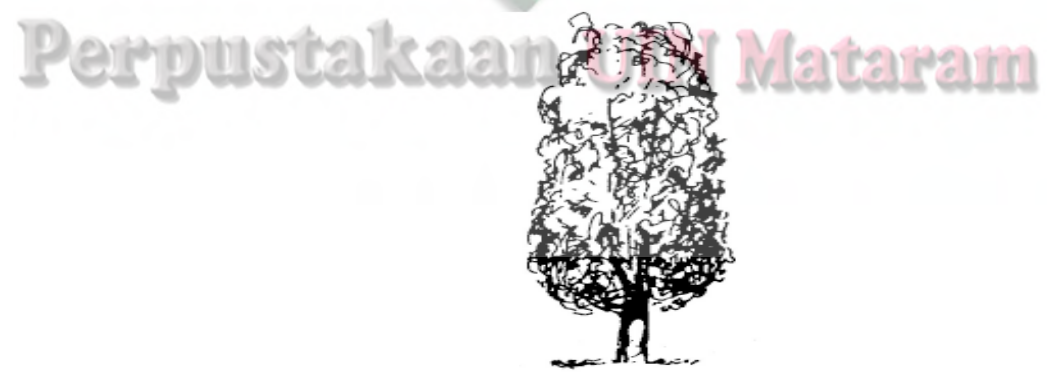

Gambar 1.2Frakınus pennsylvancia

\section{b. Pyramidal}

1) Tinggi $15-20$

Pengelompokan pertama dari tekstur pyramidal dengan tinggi pohon berkisar 15-20 m 
a) Nama botani

Adapun nama botani tumbuhan dengan tekstur pyramidal dengan ketinggian 15-20 m adalahMalus „Red Jewel

b) Nama umum

Adapun nama umum dan dikenal khalayak umum tumbuhan dengan tekstur pyramidal adalahRed Jewel Crabapple

2) Tinggi $>20-45$

Pengelompokan kedua dari tekstur pyramidal dengan tinggi pohon berkisar $20-45 \mathrm{~m}$.

a) Nama botani

UNIVERSITAS ISLAM NEGER

M Adapun ${ }^{A}$ nama $^{\mathrm{A}}$ botani tumbuhan dengan tekstur pyramidal dengan ketinggian 20-45 m adalah Betulus platyphylla japonica 'Whitespire, Cercidiphyllum japonicum, Ginkgo biloba ,Autumn Gold

b) Nama umum

Adapun nama umum dan dikenal khalayak umum tumbuhan dengan tekstur pyramidal yaitu : Whitespire Birch, Katsura Tree, Autumn Gold.

3) tinggi $>45$

Pengelompokan ketiga dari tekstur pyramidal dengan tinggi pohon berkisar lebih dari $45 \mathrm{~m}$. 
a) Nama botani

Adapun nama botani tumbuhan dengan tekstur pyramidal dengan ketinggian lebih dari $45 \mathrm{~m}$ adalah*Abies

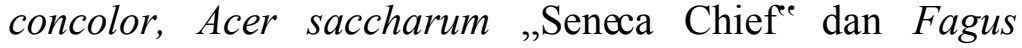
sylvatica

b) Nama umum

Adapun nama umum dan dikenal khalayak umum tumbuhan dengan tekstur pyramidal yaitu : White Fir, Seneca Chief Sugar Maple dan European Beech

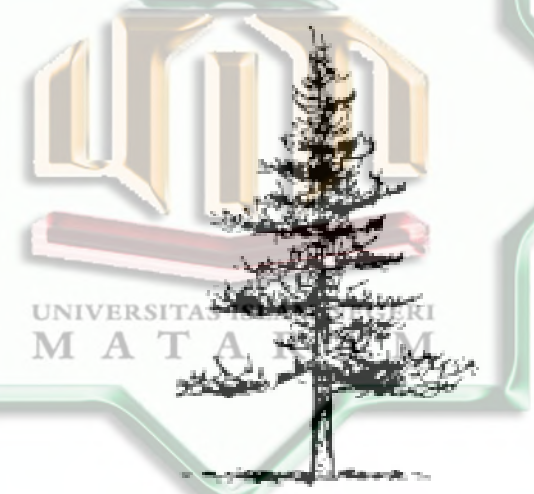

Gambar 1.3Picae Obovata

c. Oval

1) Tinggi $15-20$

Pengelompokan pertama dari tekstur oval dengan tinggi pohon berkisar lebih dari 15-20 m.

a) Nama botani

Adapun nama botani tumbuhan dengan tekstur oval dengan ketinggian lebih 15-20 m adalahAcer buergeranum, 
Amelanchier x grandiflora „Autumn Brilliance ${ }^{e e}$ dan Chionanthus virginicus

b) Nama umum

Adapun nama umum dan dikenal khalayak umum tumbuhan dengan tekstur oval yaitu: Trident Maple, AutumnBrilliance Serviceberry dan White Fringe Tree

2) Tinggi $>20-45$

Pengelompokan kedua dari tekstur oval dengan tinggi pohon berkisar 20-45 m.

a) Nama botani

Adapun nama botani tumbuhan dengan tekstur oval dengan ketinggian lebih 20-45 m adalahAcer x freemanii UNIVERSITAS ISLAM NEGERI „Jeffersred platanoides ,Emerald Queen.

b) Nama umum

Adapun nama umum dan dikenal khalayak umum tumbuhan dengan tekstur oval yaitu: Autumn Blaze Maple, Crimson King Maple dan Emerald Queen Maple.

3) Tinggi $>45$

Pengelompokan keriga dari tekstur oval dengan tinggi pohon lebih dari $45 \mathrm{~m}$. 
a) Nama botani

Adapun nama botani tumbuhan dengan tekstur rounded dengan ketinggian lebih dari $45 \mathrm{~m}$ adalahAcer saccharum, Celtis occidentalisdan Fraxinus americana,,Autumn Applause

b) Nama umum

Adapun nama umum dan dikenal khalayak umum tumbuhan dengan tekstur rounded yaitu: Sugar Maple, Hackberry dan Autumn Applause White Ash

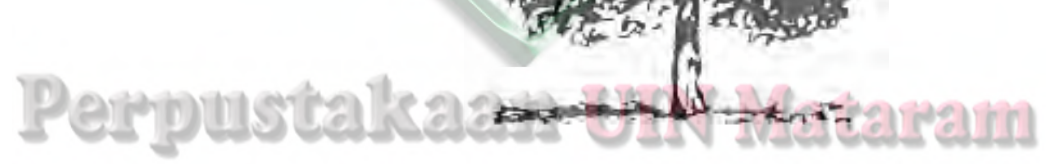

Gambar 1.4 Acer campestre

d. Rounded

1) Tinggi $15-20$

Pengelompokan pertama dari tekstur rounded dengan tinggi pohon berkisar $15-20 \mathrm{~m}$.

a) Nama botani

Adapun nama botani tumbuhan dengan tekstur rounded dengan ketinggian berkisar 15-20 m adalahAcer 
buergeranum, Amelanchier grandiflora „Princess Diana" dan Amelanchier,,Cumulus ${ }^{\text {ee }}$

b) Nama umum

Adapun nama umum dan dikenal khalayak umum tumbuhan dengan tekstur rounded yaitu: Trident Maple, Princess Diana Serviceberry dan Cumulus Serviceberry

2) Tinggi $>20-45$

Pengelompokan kedua dari tekstur rounded dengan tinggi pohon berkisar 20-45 m.

a) Nama botani

Adapun nama botani tumbuhan dengan tekstur rounded dengan ketinggian berkisar 15-20 m adalahAcer rubrum ",Autumn AFlame,,Acer truncatum x A. platanoides Warrenred dan Aesculus x carnea „Briottiie

b) Nama umum

Adapun nama umum dan dikenal khalayak umum tumbuhan dengan tekstur rounded yaitu: Autumn Flame Red Maple, Pacific Sunset Maple dan Briotti Red Horsechestnut.

3) Tinggi $>45$

Pengelompokan ketiga dari tekstur rounded dengan tinggi pohon lebih dari $45 \mathrm{~m}$.

a) Nama botani 
Adapun nama botani tumbuhan dengan tekstur rounded dengan ketinggian lebih dari 45 adalahAcer saccharum, Acer saccharum Flax Mill Majesty"e dan Fagus grandifolia

b) Nama umum

Adapun nama umum dan dikenal khalayak umum tumbuhan dengan tekstur rounded yaitu: Sugar Maple, Flax Mill Majesty, Sugar Maple, American Beech dan White Oak.

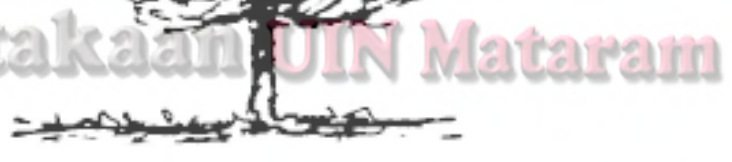

Gambar 1.5Sorabus aucuparia

\section{e. Spreading}

1) Tinggi $15-20$

Pengelompokan pertama dari tekstur spreading dengan tinggi pohon berkisar 15-20 m. 
a) Nama botani

Adapun nama botani tumbuhan dengan tekstur spreading dengan ketinggian 15-20 m adalahAcer ginnala „Flame”, Acer palmatum, Cercis canadensis texensis „Oklahoma“Cornus mas

b) Nama umum

Adapun nama umum dan dikenal khalayak umum tumbuhan dengan tekstur spreading yaitu: Flame Amur Maple, Japanese Maple dan Oklahoma Redbud.

2) Tinggi $>20-45$

Pengelompokan kedua dari tekstur spreading dengan tinggi pohon berkisar $20-45 \mathrm{~m}$

a) Nama botani T A R A M

Adapun nama botani tumbuhan dengan tekstur spreading dengan ketinggian 20-45 m adalahCarpinus japonica, Cercis canadensisdan Cornus florida.

b) Nama umum

Adapun nama umum dan dikenal khalayak umum tumbuhan dengan tekstur spreading yaitu: Japanese HornbeamRedbud dan Flowering Dogwood

3) Tinggi $>45$

Pengelompokan ketiga dari tekstur spreading dengan tinggi pohon lebih dari $45 \mathrm{~m}$. 
a) Nama botani

Adapun nama botani tumbuhan dengan tekstur spreading dengan ketinggian lebih dari $45 \mathrm{~m}$ adalahMalus floribunda, Prunus sargentidan Prunus yeodensis

b) Nama umum

Adapun nama umum dan dikenal khalayak umum tumbuhan dengan tekstur spreading yaitu: Japanese Flowering, Crabapple, Sargent Cherry dan Yoshino Cherry.

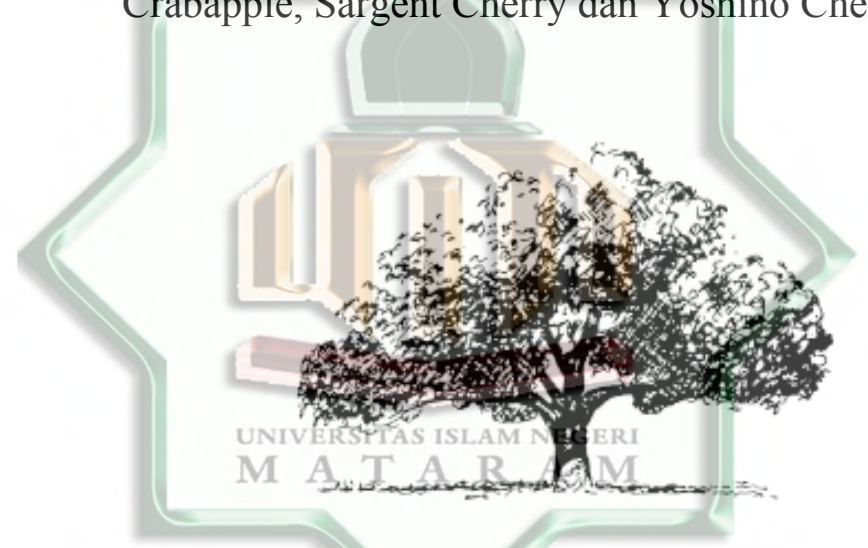

\section{Gambar 1.6 Juglans regia}

\section{f. Vase (Upright Spreading)}

1) Tinggi $15-20$

Pengelompokan pertama dari tekstur vase dengan tinggi pohon berkisar 15-20 m.

a) Nama Botani

Adapun nama botani tumbuhan dengan tekstur vase dengan ketinggian $15-20 \mathrm{~m}$ adalahAcer palmatum „Moonfire ${ }^{e e}$ Acer palmatum „Bloodgoode dan Aronia arbutifolia „Brilliantissima 
b) Nama umum

Adapun nama umum dan dikenal khalayak umum tumbuhan dengan tekstur vase yaitu:Moonfire Japanese Maple, Bloodgood Japanese Maple dan Brilliant Red Chokeberry

2) Tinggi $>20-45$

Pengelompokan kedua dari tekstur vase dengan tinggi pohon berkisar 20-45 $\mathrm{m}$.

a) Nama botani

Adapun nama botani tumbuhan dengan tekstur vase

dengan ketinggian 20-45 m adalahAcer griseum, Acer rubrum Franksred ${ }^{\text {ee }}$ dan Cladrastis lutea.

b) Nama umum A R A M

Adapun nama umum dan dikenal khalayak umum tumbuhan dengan tekstur vase yaitu: Paperbark Maple, Red Sunset Red Maple dan Yellowwood

3) Tinggi $>45$

Pengelompokan ketiga dari tekstur vase dengan tinggi pohon lebih dari $45 \mathrm{~m}$.

a) Nama botani

Adapun nama botani tumbuhan dengan tekstur vase dengan ketinggian 20-45 m adalahUlmus Pioneer', Ulmus parvifolia „Dynasty“e dan Ulmus parvifolia „Emer I ${ }^{\text {ee }}$ 
b) Nama umum

Adapun nama umum dan dikenal khalayak umum tumbuhan dengan tekstur vase yaitu: Pioneer Elm, Dynasty Elm dan Athena Elm.

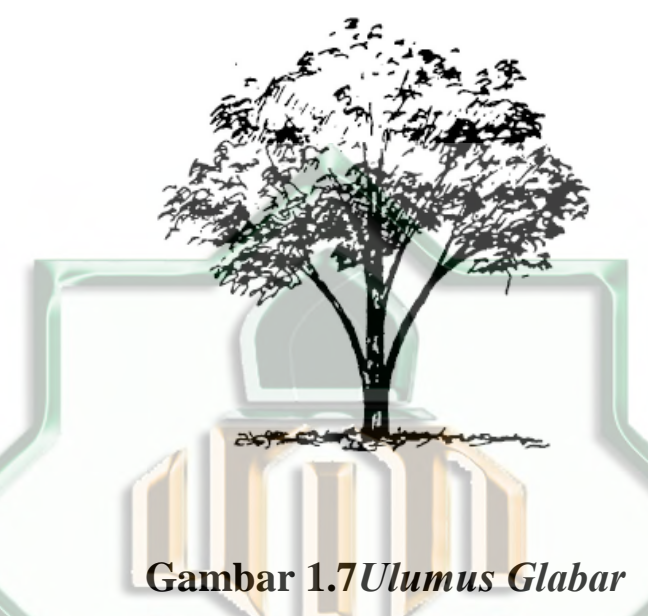

g. Weeping

1) tinggi $15-20 \mathrm{~T} A \mathrm{R} A \mathrm{M}$

Pengelompokan pertama dari tekstur weeping dengan tinggi pohon berkisar $15-20 \mathrm{~m}$.

a) Nama botani

Adapun nama botani tumbuhan dengan tekstur weeping dengan ketinggian 15-20 m adalahAcer palmatum „Crimson Queen", Acer palmatum 'Ever Red ${ }^{\text {ee }}$ dan Betula pendula ,Youngii

b) Nama umum

Adapun nama umum dan dikenal khalayak umum tumbuhan dengan tekstur weeping yaitu: Crimson Queen 
Japanese Maple, Ever Red Japanese Maple dan Younges Weeping Birch.

2) Tinggi $>20-45$

Pengelompokan kedua dari tekstur weeping dengan tinggi pohon berkisar 20-45 $\mathrm{m}$.

a) Nama botani

Adapun nama botani tumbuhan dengan tekstur weeping dengan ketinggian 20-45 adalah Betula pendula, Fagus sylvatica „Pendula", Prunus subhirtella „Pendula Plena Rosea ${ }^{e e}$ dan Prunus x ,Snofozam ${ }^{e e}$

b) Nama umum

Adapun nama umum dan dikenal khalayak umum UNIVERSITAS ISLAM NEGER

tumbuhan dengan tekstur weeping yaitu: European White Birch, Weeping Beech, Double Weeping Cherry dan Snow Fountain Cherry

3) Tinggi $>45$

Pengelompokan keiga dari tekstur weeping dengan tinggi pohon lebih dari $45 \mathrm{~m}$.

a) Nama botani

Adapun nama botani tumbuhan dengan tekstur weeping dengan ketinggian lebih dari 45 adalah Salix alba,,Tristise, ${ }^{\mathrm{e}}$ Salix babylonicadan Salix matsudana „Tortuosa. 
b) Nama umum

Adapun nama umum dan dikenal khalayak umum tumbuhan dengan tekstur weeping yaitu: Golden Weeping Willow, Weeping dan WillowContorted Willow. ${ }^{16}$

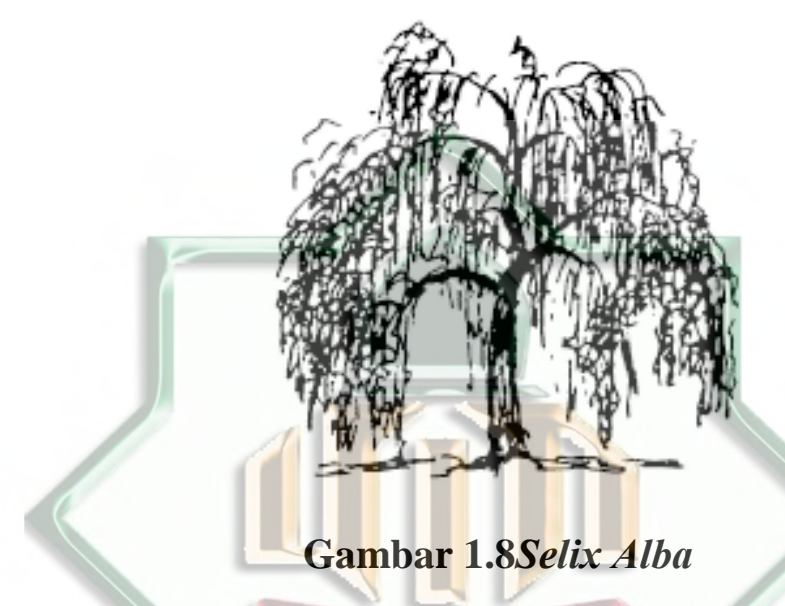

\section{c. Ecosystem Services (Pelayanan Ekosistem)}

Pelayanan ekosistem (ecosystem services) pada dasarnya sudah kita rasakan baik secara sadar maupun tidak. Pada dasarnya ecosystem services menyediakan pelayanan secara langsung atau tidak langsung berupa kontribusi untuk meningkatkan kesejahtraan manusia. Kajian ini sudah dikembangkan sejak tahun 1990-an sebagai langkah untuk mengembangkan keefektipan dari interaksi yang terjadi antara lingkungan dan mahluk hidup sehingga keamanan terhadap keanekaragaman mahluk hidup (biodiversity) bisa terjaga. Ecosystem services dikategorikan menjadi empat tipe: 1) pelayanan kebutuhan hidup (provisioning

\footnotetext{
${ }^{16}$ Wayne K. Clatterbuck, "Cooperative Extension Work Inagriculture And Home Economics, The University of Tennessee Institute of Agriculture, U.S. Department of Agriculture, and county governments cooperating in furtherance of Acts of May 8 and June 30, 1914. Agricultural Extension Service, Billy G. Hicks, Dean.
} 
services); 2) pelayanan keteraturan (regularity services); 3) pelayanan tempat tinggal (habitat services); dan 4) pelayanan budaya (cultural services). Masing-masing tipe Ecosystem services. ${ }^{17}$

Menurut sejarah, manusia dapat memodifikasi ekosistem alami yang dapat diubah menjadi berbagai bentuk yang bermanfaat seperti agrikultural dan layanan ekosistem (seperti penyerbukan, kesuburan tanah dan pencegah erosi). Beberapa layanan ekosistem seperti regulasi dan stabilisas temperatur, aliran sungai, air terjun dan penyebaran nutrien tak sebanyak atau berkurang dengan bertambahnya waktu dan ketika gangguan atau perubahan yang dapat memperburuk layanan ekosistem. ${ }^{18}$

Layaknya sebuah sistem, ekosistem dapat saja berkerja dengan baik sampai dengan akhirya mengalami kerusakan dan dikontrol oleh pendeteksi gejala seperti fisheriers sebuah sistem yang bekerja stabil pada keadaan atau level penangkapan yang cukcup stabil untuk beberapa tahun. Contoh lainnya adalah memperjelas landscape dengan cara memodif bentuk vegetasi rerumputan yang menunjukkan sistem perakaran yang dangkal dan sekaligus penyerapan air ke dalam tanah yang merupakan hal terpenting unutuk kelangsungan hidup tumbuhan. Beberapa layanan ekosistem tidak mudah untuk diobservasi sampai berhenti untuk berkembang, karena layanan ekosistem berdampak pada komponen yang lain didalamnya. Oleh karena itu, tidak dapat dinominalkan dalam sistem

\footnotetext{
17 Didier Bourguignon. 2015. Ecosystem Services Valuing Our Natural Capital. European Parliamentary Research Service.

${ }^{18}$ Didier Bourguignon. 2015. Ecosystem Services Valuing Our Natural Capital. European Parliamentary Research Service. Hal. 2
} 
ekonomi. Perbaikan dan pemulihan ekosistem alami dan pelayanannya yang telah dikembangkan sebelumnya yang bermanfaat dapat diteruskan. ${ }^{19}$.

\section{d. Ruang Terbuka Hijau (RTH)}

Kawasan yang termasuk dalam pengertian RTH ditentukan sesuai instruksi Mendagri No.14/1988 tentang penataan di wilayah Perkotaan sebagai berikut : 1) kawasan atau ruang kota berfungsi sebagai kawasan hijau pertamanan kota, kawasan hutan kota, kawasan hijau rekreasi kota, kawasan hijau kegiatan olah raga, kawasan hijau pemakaman, kawasan pertanian, kawasan jalur hijau, dan kawasan pekarangan, 2)ruang-ruang dalam kota berupa kawasan memanjang berupa jalur yang bersifat terbuka tanpa bangunan, dan 3)bersifat pengisian hijau tanaman atau tumbuhan secara alamiah atau budidaya tanaman, seperti lahan pertanian, pertamanan, perkebunan, dan lainnya. Keberadaan RTH yang cukup luas menyerupai hutan kota akan dapat memperbaiki kondisi lingkungan di perkotaan. Oleh karenanya model RTH dapat meningkatkan kualitas lingkungan hidup kota, antara lain sebagai pelindung dari radiasi dinar mathari, merupakan suhu kota, menngkatkan kelembaban udara, mengurangi kecepatan angin,

${ }^{19}$ The Hon. Peter Garrett AM MP.. ECOSYSTEM SERVICES: KEY CONCEPTS AND APPLICATIONS Occasional Paper Series No.1.Department of the Environment, Water, Heritage and the Arts:Australia.2009 
dandapat memenuhi fungsi estetika, serta dapat dimanfaatkan untuk melakukan berbagai aktivitas social-budaya warga kota. ${ }^{20}$

\section{e. Kenyamanan Berkendara}

Kenyamanan berkendara dalam penelitian ini lebih difokuskan dalam pengendara speda motor. Speda motor sendiri merupakan sarana transportasi darat yang digunakan oleh sebagian besar orang Indonesia untuk mengakses tujuan ajarak dekat atau jarak jauh. Seorang yang mengendarai speda motor akan merasakan gangguan baik dari mesin speda motor atau dari paparan lingkungan berupa debu, panas matahari dan berbagai gangguan bising lainnya. Faktor kenyamanan dalam berkendara menjadi sangat penting untuk perhatikan supaya tidak terjadi gangguan dalam proses berkendara, ada banyak factor yang mempengaruhi kenyamanan dan kesetabilan dalam berkendara, salah satunya akibat paparan sinar matahari lagsung. Akibat permasalahan tersebut banyak terjadi pelanggaran terhadap rambu-rambu lalulintas pada saat berhenti di area persimpangan jalan yang memiliki traffic ligh, seperti menerobos lampu merah, berhenti tidak pada lajur jalan yang sudah ditentukan dan lain sebagainya. Untuk itu kenyamanan dalam berkendara sangat diperlukan mengingat hal ini bagian penting

\footnotetext{
${ }^{20}$ Setyowati, D. L. 2008. Iklim Mikro dan Kebutuhan Ruang Terbuka Hijau di Kota Semarang.Jurnal Manusia dan Lingkungan, 15 (3): 125-140.
} 
bagi pengendara untuk mampu berkonsentrasi saat berada di jalan raya. $^{21}$

\section{f. Index Naturalness}

Konsep index naturalness (tingkat kealamian) merupakan tingkat kealamian pada suatu wilayah tertentu.Ranking index naturalness dikategorikan pada rentang nilai maksimum 10 untuk sistem alami absolut sampai dengan nilai minimum (0) untuk sistem buatan absolut (Machado, 2004). ${ }^{22}$

Tabel 1.1.Katagori index naturalness

\begin{tabular}{|c|l|c|}
\hline $\begin{array}{l}\text { Katagori Index } \\
\text { Naturalness }\end{array}$ & Warna \\
\hline$[10]$ & $\begin{array}{l}\text { Sistem yang sangat alami (absolut). Jarang atau } \\
\text { hampir tidak ditemukan (kemungkinan tidak } \\
\text { ditemukan) polusi. }\end{array}$ & \\
\hline$[9]$ & $\begin{array}{l}\text { Sistem yang alami menghadirkan sedikit } \\
\text { elemen biologi yang eksotik. Polusi baik fisika } \\
\text { dan kimia tidak ada/tidak terdeteksi. }\end{array}$ & \\
\hline$[8]$ & $\begin{array}{l}\text { Sistem subnatural, keberadaannya biasa } \\
\text { ditentukan keberadaan dengan spesies liar, } \\
\text { tetapi tidak dampak yang sedikit. Sesekali } \\
\text { polusinya diperoleh oleh adanya sistem } \\
\text { dominan. Dan bahkan tidak terbuang ke } \\
\text { lingkungan. }\end{array}$ & \\
\hline$[7]$ & $\begin{array}{l}\text { Sistem quasi nstural, rendahnya dampak fisika } \\
\text { akibat aktivitas perluasan antropik. Struktur } \\
\text { kealamian telah dimodifikasi tetapi tidak } \\
\text { membahayakan, terdapat sedikit perubahan } \\
\text { dinamia air. }\end{array}$ & \\
\hline$[6]$ & $\begin{array}{l}\text { Semi natula sistem, infrastuktur antropik yang } \\
\text { langka atau pekat. Kemungkinan didominasi } \\
\text { oleh spesies eksotik liar. Elemen yang asli } \\
\text { sangat dikurangi. Sesekali penambahan energy }\end{array}$ & \\
\hline
\end{tabular}

${ }^{21}$ Chika Oliviani dan Harus Laksana Guntur. 2014. Analisa Kenyamanan Kendaraan Roda Duadengan Pemodelan Pengendara sebagai Multi-Sistem. Jurnal Teknik Pomits. Vol. 3, Hal. 57-60 110.

${ }^{22}$ Machado, A. 2004.An Index of Naturalness.Journal of Nature Conservation, 12, 95 - 


\begin{tabular}{|c|c|}
\hline & $\begin{array}{l}\text { dan ekstraksi dari sumber terbarukan atau } \\
\text { material yang nonrelevan. Secara umu } \\
\text { pergerakan masih terkontrol oleh proses air. }\end{array}$ \\
\hline [5] & $\begin{array}{l}\text { Sistem budaya yang dikelola sendiri, proses } \\
\text { mengondisikan aktivitas manusia yang luas, } \\
\text { produksi biologi terlalu dipaksakan. Spesies } \\
\text { asli diubah sesekali diubah. Sedikit atau tidak } \\
\text { adanya konstruksi atau artefak. Sedikit atau } \\
\text { tidak ada pengelolaan siklus pasif. }\end{array}$ \\
\hline [4] & $\begin{array}{l}\text { Sistem bantuan budaya, infrastruktur dan } \\
\text { pengkondisian lingkungan fisik yang penting, } \\
\text { penambahan materi secara moderat (biasanya } \\
\text { disertai polusi). Elemen alami bercampur } \\
\text { dengan kreasi manusia, di tambah atau koridor. } \\
\text { Pengelolaan wafer yang aktif. }\end{array}$ \\
\hline [3] & $\begin{array}{l}\text { Sistem yang sangat terintervensi, masih } \\
\text { merupakan daerah dengan produksi biologis } \\
\text { (alami/budidaya/peternakan) yang dicampur } \\
\text { dengan bangunan dan infrastruktur. } \\
\text { Keanekaragaman hayati alami berkurang } \\
\text { drastis, unsur-unsurnya agak, geomorfologi } \\
\text { biasanya berubah atau dihapus. }\end{array}$ \\
\hline [2] & $\begin{array}{l}\text { Sistem transformasi, produksi biologis tidak } \\
\text { dominan terhadap pembentukan elemen } \\
\text { bangunan. Perkembangan moderat vertical } \\
\text { terhadap fasilitas masukan energy dan materi } \\
\text { yang tidak biasa (makanan, air) dari luar. } \\
\text { Pengontrolan air secara intensif. }\end{array}$ \\
\hline [1] & $\begin{array}{l}\text { Sistem yang mengalami berubahan, } \\
\text { dikembangkan oleh proses antropilk, dominasi } \\
\text { elemen artistik yang jelas, perkembangan } \\
\text { vertical yang intensif, masih terdapat sisa } \\
\text { elemen-elemen, ketergantungan penuh dari } \\
\text { input internal dan energi. }\end{array}$ \\
\hline$[0]$ & $\begin{array}{l}\text { Sistem artifisia, penutupan tinggi tanpa } \\
\text { mendapatkan kehidupan makroskopik, bahkan } \\
\text { mikroskopik tidak ada atau wadah-wadah } \\
\text { alami. }\end{array}$ \\
\hline
\end{tabular}

\section{Penelitian Terdahulu}

a. Imawan Wahyu Hidayat (2010) tentang Kajian Fungsi Ekologi Jalur

Hijau Jalan Sebagai Penyangga Lingkungan Pada Tol 
Jagorawi.Penelitian konservatif ini bertujuan untuk mengevaluasi jalur hijau jalan Tol Jagorawi sebagai penyangga dan pendukung keamanan serta kenyamanan pengguna kendaraan bermotor dengan tiga fungsi utama, yaitu pereduksi polusi udara, peredam kebisingan, dan penghalang sinar matahari langsung. Metode komparatif digunakan untuk mengukur kesesuaian dan ketepatan tanaman pada jalur hijau jalan Tol Jagorawi berdasarkan peraturan dan prinsip ilmu arsitektur lanskap. Hasil studi mengindikasikan bahwa pemilihan tanaman, struktur, pola, dan konfigurasinya tidak sesuai dan tidak tepat untuk mendukung fungsi-fungsi tersebut. Jalur hijau jalan pada seluruh segmen mencapai tingkatan sedang: 44,26\% (I), 47,54\%-50,32 (II), 49,35\%-50,74\% (III). Studi ini merekomendasikan bahwa perencanaan jalur ${ }^{\mathrm{A}}$ hijau ${ }^{\mathrm{A}}$ jalan ${ }^{\mathrm{A}}$ yng baik memerlukan pemilihan tanaman yang tepat berdasarkan struktur, performa, pola penanaman, dan konfigurasinya untuk mencapai keefektifan peran ekologi jalur hrjau jalan sebagai penyangga lingkungan dan mendukung kenyamanan berkendara pada Tol Jagorawi. ${ }^{23}$

b. Penelitian Kartika Sari Hanafri (2011) tentang Analisis Manfaat Kanopi Pohon dalam Mereduksi Polutan Udara Menggunakan Program City-green di Jalan Raya Padjajaran, Kota Bogor. Penelitian ini bertujuan untuk menganalisis manfaat kanopi pohon dalam menjerap dan menyaring polusi udara disepenjang jalur hijau Jalan

\footnotetext{
${ }^{23}$ Imawan Wahyu Hidayat. 2010. Kajian Fungsi Jalur Hijau Jalan Sebagai Penyangga Lingkungan pada Tol Jagorawi. Jurnal Manusia dan Lingkungan. Vol. 12. Hal.124-133.
} 
Raya Padjajaran, Kota Bogor. Jalan tersebut merupakan jalan utama yang memiliki aktivitas transportasi terpadat di Kota Bogor. Metode yang digunakan adalah GIS, menggunakan prangkat lunak ArcView 3.2 ekstensi City-green 5.4, kemampuan pohon dalam mereduksi polutan diudara dapat dianalisis melalui pendekatan berdasarkan luasan kanopi pohon. Berdasarkan hasil analisis City-green 5.4, polutan udara yang dapat direduksi oleh kanopi pohon adalah sebesar $565,63 \mathrm{~kg}$ atau senilai dengan penghematan biaya sebesar $\mathrm{Rp}$ 29.481.600,-. Perbandingan dengan udara ambien, kemampuan pohon dalam melakukan pembersihan polusi di udara ternyata tidak cukup untuk menjerap jenis polutan partikel. Sehingga luas penutupan kanopi pohon yang awalnya 5,82 ha, setidaknya perlu ditingkatkan luasannya minimal menjadi 6,33 ha atau menambah 0,51 ha luas kanopi pohon. ${ }^{24}$

c. Penelitian Sitawati dan Agus Suryanto (2012), tentang Model Keterpaduan Pohon dalam Menentukan Indeks Kenyamanan Ruang Terbuka Hijau (RTH). Tujuan penelitian ini adalah mendapatkan bentuk dan struktur RTH pada tingkat kenyamanan yang optimal. Mendapatkan peranan dan ciri pohon pada tingkat kenyamanan. Penelitian dilakukan di kota Malang Jawa Timur, dengan tinggi tempat $440-667$ mdpl pada $26 \mathrm{RTH}$ dengan luasan $\geq 400 \mathrm{~m}^{2}$. Sebagai pembanding, data juga diambil dari Kebun Raya Purwodadi,

\footnotetext{
${ }^{24}$ Kartika Sari Hanafri. 2011. Analisis Manfaat Kanopi Pohon dalam Mereduksi Polutan Udara Menggunakan Program City-green di Jalan Raya Padjajaran, Kota Bogor. Institut Pertanian Bogor Press.
} 
Lembaga Ilmu Penelitian Indonesia (LIPI) di Kabupaten Pasuruan, dengan ketinggian tempat sekitar $400 \mathrm{mdpl}$ dan terletak pada $112^{\circ}$ $113^{\circ}$ BT dan $70^{\circ}-80^{\circ}$ LS. Morfologi pohon dan kemampuan menurunkan suhu ialah bentuk tajuk rounded (46\%) dengan kemampuan menurunkan suhu $(2,07+0,72)^{\circ} \mathrm{C}$, percabangan simpodial $(2,01+0.61)^{\circ} \mathrm{C}$, tekstur daun halus $(1,91+0,59)^{\circ} \mathrm{C}$, warna daun gelap $(1,82+0,78)^{\circ} \mathrm{C}$. Kelompok Palmae (Kelapa Sawit, Palem Putri, Palem Raja, Palem Putri, Palem Ekor Tupai, Kelapa), Dewandaru, Genitri, Kelengkeng, Ketepeng dan Kluwih memilki kemampuan menurunkan suhu yang rendah $\left(0,1^{\circ} \mathrm{C}\right)$, sedang Kiara Payung (Filicium decipiens) memiliki kemampuan menurunkan suhu udara di bawah tajuk tertinggi $\left(3.8^{\circ} \mathrm{C}\right)$ dengan kerapatan tajuk $90 \%$. Peningkatan penutupan tajuk pohon dalam RTH akan diikuti dengan penurunan suhu secara kuadratik dengan persamaan $y=-0.001 x^{2}+$ 0.118x +28.79 .5 . Pada tahun 2010 terdapat 25 desa nyaman di Kota Malang dengan THI $<27$ dan diperkirakan pada tahun 2050 tidak terdapat satu wilayahpun yang memiliki THI $<27 .^{25}$

d. Penelitian Lougner C.P., dkk (2012) terkait peran kanopi pohon untuk mengurangi efek heat island dengan judul lengkap Roles of Urban Tree Canopy and Buildings in Urban Heat Island Effects: Parameterization and Preliminary Results. Berdasarkan penelitian ini

\footnotetext{
${ }^{25}$ Sitawati dan Agus Suryanto. 2012. Model Keterpaduan Pohon dalam Menentukan Indeks Kenyamanan Ruang Terbuka Hijau (RTH). Laporan Akhir Hasil Penelitian Unggulan Perguruan Tinggi-Hibah Bersaing (Tahun Ke-1) Tahun Anggaran 2012. DIPA Universitas Brawijaya.
} 
dapat kita ketahui peran penting tumbuhan yang berada di wilayah perkotaan terutama berperan sebagai kanopi di pemukiman dan sepanjang jalan raya, selain untuk mereduksi polusi udara yang terlepaskan oleh kendaraan bermotor juga mampu memberikan rasa nyaman untuk beraktifitas di luar ruangan. Penelitian ini memanfaatkan metode WRF-UCM (Weather Research and Forcasting and Urban Canopy Model) dengan menganalisis mulai dari naungan rumput, bangunan dan pohon. Modifikasi model penanaman pohon sekitar 50\% mampu mengurangi suhu di sekitar jalan raya di wilayah perkotaan antara $0,8^{\circ} \mathrm{C}-15,4^{\circ} \mathrm{C}$ sedangkan kanopi dari rumput dan bangunan hanya mampu menurunkan Heat Island hanya sekitar $0,1^{\circ} \mathrm{C} .^{26}$

e. Penelitian Dewi Liesnoor Setiyowati (2008) yang terkait tentang iklim mikro dan kebutuhan ruang terbuka hijau (RTH). Tujuan dari penelitian ini adalah memetakan sebaran $\mathrm{RTH}$, mengevaluasi kondisi iklim mikro, dan menghitung kebutuhan RTH untuk memperbaiki kondisi kondisi iklim mikro. Objek penelitian berupa kawasan RTH dan kawasan jalur jalan. Penentuan sampel penelitian untuk kawasan jalur jalan menggunakan teknik "purposive sampling”, berdasarkan karakteristik tertentu dangan pertimbangan: terdapat perbedaan jenis dan jumlah vegetasi, terdapat variasi iklim harian, perbedaan iklim mikro, tingkat kenyamanan berbeda pada pagi, siang, dan sore.

${ }^{26}$ Loughner C.P., dkk. 2012. Roles of Urban Tree Canopy and Buildings in Urban Heat Island Effects: Parameterization and Preliminary Results. Journal Applaid Meteorology and Climatology. Vol.15, Hal. 1775-1793. 
Penentuan sampel untuk variabel sebaran vegetasi meliputi jenis jenis dan kerapatan vegetasi dilakukan dengan cara sensus pada setiap lokasi pengamatan, khususnya tanaman yang tinggi batangnya lebih dari 3 (tiga) meter. Sampai variabel iklim mikro meliputi temperature, kelembaban udara, dan indeks kenyamanan. ${ }^{27}$

f. Penelitian Prasetio, dkk (2016) yang terkait tentang Studi deskripsi hubungan antara Naturalness Index dan Biodiversity Index dengan iklim mikro berbasis Ecological Landscape. Metode yang digunakan pada masing-masing kelurahan ditentukan tiga titik sampel dengan menggunakan fasilitas google map; sedangkan pencarian lokasi yang sesuai titik koordinat menggunakan alat GPS. Analisis landscape yang digunakan pada penelitian ini meliputi naturalness index berdasarkan pada penjelasan Machado ${ }^{\mathbb{R}}(2004)^{M}$ dan IndeksBiodiversitas yang dikembangkan oleh Pagiola (2004) sebagaiprediktor. Dari penelitian ini dapat ditarik kesimpulan bahwa konservasi RTH perlu dipertimbangkan dalam laju pembangunan dan penggunaan indeks untuk menilai kondisi landskape perkotaan dapat menggunakan naturalness index dan indeks kualitas biodiversitas yang terintegrasi ${ }^{28}$.

\footnotetext{
${ }^{27}$ Setyowati, D. L. 2008. Iklim Mikro dan Kebutuhan Ruang Terbuka Hijau di Kota Semarang.Jurnal Manusia dan Lingkungan, 15 (3): 125-140.

${ }^{28}$ Prastiyo, dkk. 2016. Studi deskripsi hubungan antara naturalness index dan biodiversity index dengan iklim mikro padaKelurahan jatimulyo, mojolangu,dan mergosono di kota malangberbasis ecological landscape. Vol. 9, Hal. 274-285.
} 


\section{F. Kerangka Teori}

Kota Mataram merupakan wilayah yang memiliki aktifitas transportasi darat yang paling sibuk di daerah Nusa Tenggara Barat. Hal ini terlihat dari intensitas dan mobilitas kendaraan bermotor terus beraktivitas dari berbagai lokasi jalan raya di wilayah Kota Mataram. Berdasarkan kondisi ini muncul masalah utama yakni meningkatnya polusi udara yang menyebabkan perubahan kondisi iklim mikro. Peningkatan suhu lingkungan tentu akan memberikan pengaruh terhadap kenyamanan beraktivitas pada siang hari, berkendara salah satu aktivitas yang dilakukan di luar ruangan dan terpapar cahaya matahari. Untuk mendapatkan kenyamanan tersebut bisa kita proleh dari layanan yang diberikan oleh lingkungan (ecosystem services). Ecosystem services bisa diperoleh dalam bentuk naungan yang diberikan oleh pohon (trees canopy) untuk mengurangi peningkatan suhu secara lokal pada suatu lokasi. Pemanfaatan dan pengembangan kanopi pohon secara tidak langsung sudah dilakukan di beberapa lokasi namun tidak secara menyeluruh. Oleh karena itu, dibutuhkan konsep dasar untuk melihat manfaat kanopi pohon bagi kenyamanan berkendara serta berdampak terhadap penurunan jumlah pelanggaran rambu-rambu lalulintas di beberapa persimpangan jalan raya Kota Mataram. 


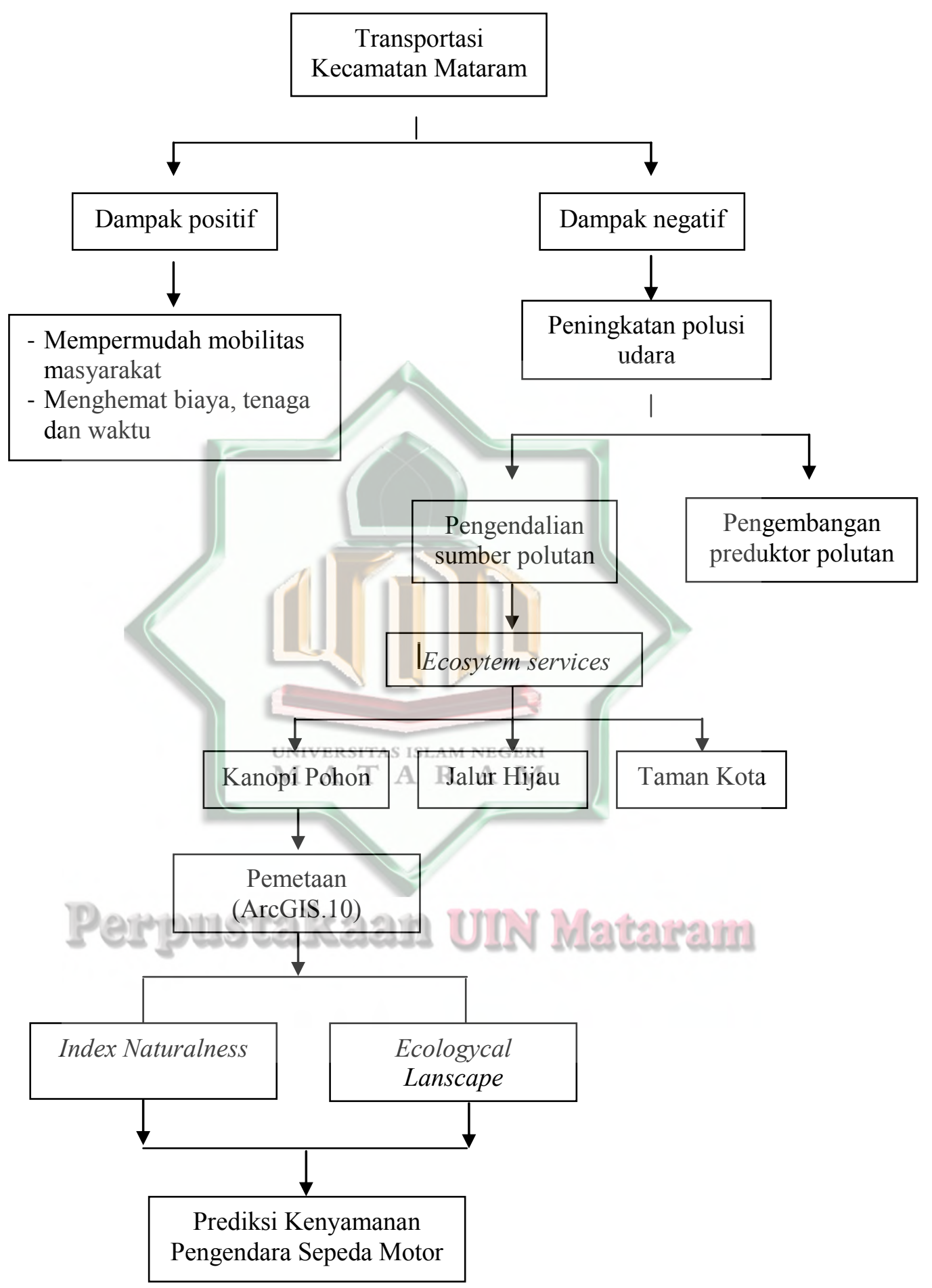

Gambar 1.9 Kerangka Teori 


\section{G. Metode Penelitian}

\section{Jenis penelitian}

Jenis penelitian yang digunakan dalam penelitian ini adalah penelitian restrospektif (Ex post facto) dengan menggunakan pendekatan kualitatif. Jenis penelitian restrospektif (Ex post facto) yaitu penelitian yang ingin mencari penyebab suatu gejala atau mengungkapkan adanya hubungan sebab akibat antara variabel yang diteliti. ${ }^{29}$

\section{Desain penelitian}

Penelitiantentang identifikasi kanopi pohon berbasis Ecologycal landscape dan Index Naturalness sebagai Ecosystem Seervices ini dilakukan dibeberapa titik perempatan jalan yang berada di kecamatan mataram. Pemetaan wilayah dilakukan dengan menggunakan sofwer ArcGISdan google eart yang sesui dengan tingkat kealamian wilayah (index naturalness). Dan angket untuk mengetahui respon pengendara motor dikecamatan mataram

3. Populasi dan sampel

a. Populasi

Populasi adalah keseluruhan objek yang menjadi pusat perhatian penelitian dan tempat untuk menggeneraliasikan temuan peneliti. ${ }^{30}$ Pada penelitian ini, yang menjadi populasi yaitu semua pohon yang terdapat di 7 pesimpangan jalan kecamatan Mataram.

\footnotetext{
${ }^{29}$ Sadjaja,Albertus herianto.2006.Panduan penelitian.jakarta:Prestasi oustaka.(Hlm: 112).
} ${ }^{30}$ Ibed (Hlm: 184). 
b. Sampel

Sampel adalah proses memilih sejumlah elemen secukupnya dari populasi. ${ }^{31}$ Pada penelitian ini menggunakan sampel total karna yang diteliti yaitu seluruh pohon yang terdapat di 7 persimpangan jalan kecamatan Mataram.

\section{Tempat dan waktu penelitian}

Penelitian ini akan dilakukan di 7 persimpangan jalan yang berada di kecamatan Mataram pada bulan Marettahun 2018.

Tabel 1.2 Lokasi penelitian

\begin{tabular}{|c|l|l|}
\hline No & \multicolumn{1}{|c|}{ Nama } & Bentuk Persimpangan \\
\hline 1 & Persimpangan Kantor gubenur & Perempatan \\
\hline 2 & Persimpangan Kamboja & Perempatan \\
\hline 3 & Persimpangan Sriwijaya & Perempatan \\
\hline 4 & Persimpangan Golkar A R A M & Perempatan \\
\hline 5 & Persimpangan STMIK & Perempatan \\
\hline 6 & Persimpangan Yaoya & Perempatan \\
\hline 7 & Persimpangan Pagutan & Perempatan \\
\hline
\end{tabular}

\section{Instrumen penelitian}

Intrumen dalam penelitian ini berupaalat tulis, Kamera digital, Peta digitasi Kecamatan Mataram, google earth, software AcrGIS dan Angket. Aspek pembagian angket ini terdiri dari enam yaitu : 1. Pemahaman responden terhadap arti penting kanopi pohon, 2. Kecukupan jumlah kanopi pohon dipersimpangan jalan kecamatan Mataram, 3. Kesehatan pohon, 4. Peran pemerintah dalam menyediakan kanopi pohon, 5 Peran

\footnotetext{
${ }^{31}$ Juliansah noor.2012.metodologi penelitian.jakarta:kencana (Hlm: 148).
} 
dan masukan masyarakat tentang kanopi pohon, dan 6. Kenyaman pengendara motor.

Tabel. 1.3Aspek pembagian angket penelitian

\begin{tabular}{|l|l|c|}
\hline No & \multicolumn{1}{|c|}{ Deskriptor } & No soal \\
\hline 1 & $\begin{array}{l}\text { Pemahaman respondens terhadap arti penting kanoi } \\
\text { pohon }\end{array}$ & $1,2,4,5$ \\
\hline 2 & $\begin{array}{l}\text { Kecukupan jumlah kanopi pohon dipersimpangan } \\
\text { jalan kecamtan mataram }\end{array}$ & 3,9 \\
\hline 3 & Kesehatan pohon & $6,7,8$ \\
\hline 4 & Peran pemerintah dalam menyediakan kanopi pohon & 14 \\
\hline 5 & peran dan masukan masyarakat tentang kanopi pohon & 13,15 \\
\hline 6 & Kenyaman pengendara motor & $10,11,12$ \\
\hline
\end{tabular}

6. Variabel penelitian

Variabel penelitian adalah suatu atribut atau sifat atau nilai dari orang, subjek atau kegiatan yang mempuyai variasi tertentu yang ditetapkan oleh peneliti untuk dipelajari dan ditarik kesimpulannya. ${ }^{32}$

a. Variabel independen

Variabel independen merupakan variabel yang mempengaruhi atau yang menjadi sebab perubahannya. Pada penelitian ini yang menjadi variabel bebasnya yaitu peran kanopi pohon berbasis ecologycal lanscape dan index naturalness sebagai ecosystem services.

\footnotetext{
${ }^{32}$ Sugiono. 2016.Metode penelitian. Bandung: Alfabeta. (Hlm: 38).
} 
b. Variabel dependen

Variabel dependen atau variabel terikat merupakan variabel yang dipengaruhi atau menjadi akibat. Pada penelitian ini yang menjadi variabel terikatnya yaitu kenyamanan pengendara sepeda motor di persimpangan jalan Kecamatan Mataram.

c. Variabel kontrol

Variabel kontrol yaitu variabel yang ikut berpengaruh pada penelitian ini. Variabel kontrol pada penelitian ini yaitu jenis kanopi pohondan luasan kanopi pohon.

\section{Teknik pengumpulan data}

Pengumpulan data pada penelitian ini dengan menggunakan software AcrGIS, google earth dan angket yaitu untuk penentuan sampel, titik koordinat persimpangan jalan dân respon pengendara motor

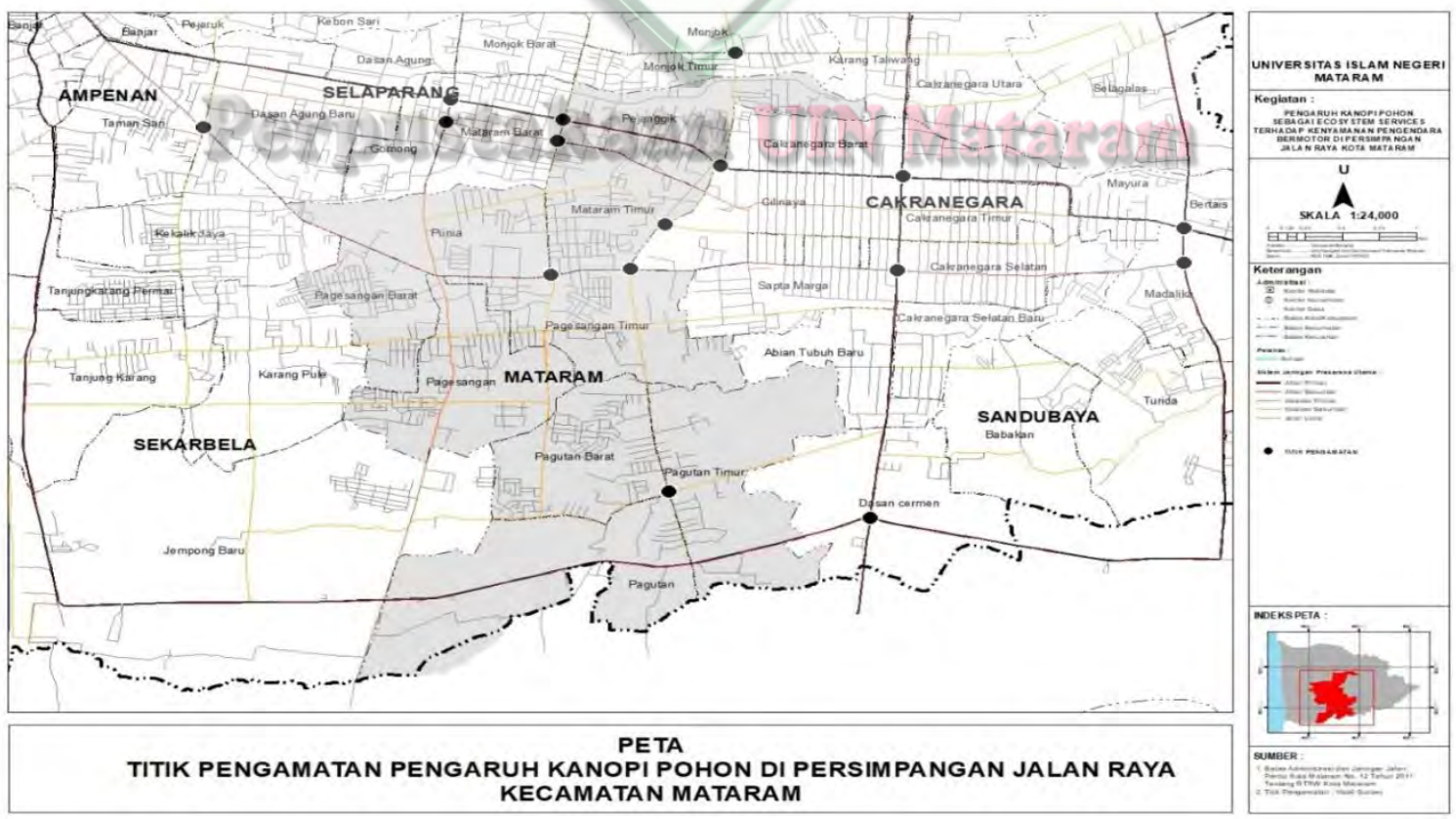

Gambar 1.10 Peta rencana wilayah pengamatan 
Tabel 1.4 Rencana pengamatan

\begin{tabular}{|l|l|c|c|c|}
\hline \multirow{2}{*}{ No } & \multirow{2}{*}{ Lokasi } & \multicolumn{2}{|c|}{ Koordinat } & \multicolumn{1}{|c|}{ Index Naturalness } \\
\cline { 3 - 5 } & & $\mathrm{X}$ & $\mathrm{y}$ & \\
\hline & & & & \\
\hline & & & & \\
\hline & & & & \\
\hline & & & & \\
\hline
\end{tabular}

\section{H. Sistematika Pembahasan}

Untuk lebih terstrukturnya, maka penulisan skripsi ini dibagi menjadi empat bab, yaitu sebagai berikut:

Bab I :Membahas tentang konteks penelitian, fokus penelitian, tujuan dan manfaat penelitian, ruang lingkup dan setting penelitian, telaah pustaka, kerangka teori, metode penelitian, dan sistematika pembahasan.

Bab II : Membahas tentang gambaran umum lokasi penelitian dan temuan data tentang kategori index naturalness di persimpangan jalan Kecamatan Mataram.

Bab III: Membahas tentang analisi terhadap temuan data dilapangan, yaitu tentang identifikasi kanopi pohon berbasis ecologycal lanscape dan index naturalness sebagai ecosystem seervices terhadap kenyamanan pengendara sepeda motor di persimpangan Jalan Kecamatan Mataram. 
Bab IV : Membahas tentang kesimpulan dari hasil analisi terhadap temuan data di lapangan dan saran. Bab ini juga merupakan penutup dari seluruh rangkaian pembahasan dalam skripsi ini.

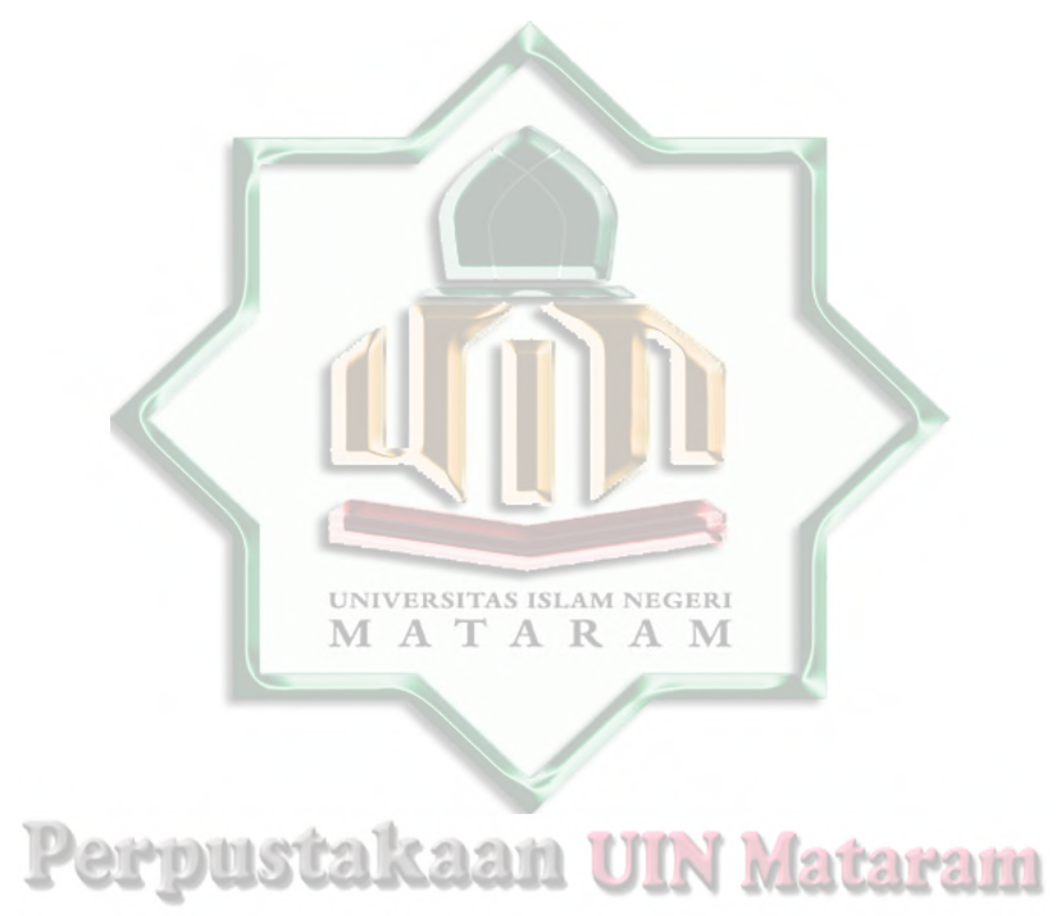




\section{BAB II}

\section{PAPARAN DATA DAN TEMUAN}

\section{A. Gambaran Umum Lokasi Penelitian}

Kecamatan Mataram yang dijadikan sebagai lokasi penelitian yang memiliki luas wilayah 1.076 Ha dan jumlah penduduk 7.945 Jiwa (BPSStatistics of Mataram City 2017). Tahun 2016 kecamatan Mataram memiliki panjang jalan $64.776 \mathrm{Km}$. dengan jalan beraspal yaitu $34.853 \mathrm{Km}$. dan jalan yang diperkeras $2913 \mathrm{Km}$. sedangkan sisanya jalan tanah sepanjang 0,01 Km. Sementara jumlah kendaraan dikecamatan Mataram mengalami peningkatan dari tahun sebelumnya yaitu 11.223 unit dengan jumlah terbanyak sepeda motor yang mencapai 9. 107 unit atau 81,15 persen. Sisanya adalah jenis kendaraan lain seperti mobil, truk, dan kendaraan umum lainnya. ${ }^{33}$ Lingkup penelitian dipusatkan pada persimpangan jalan kecamatan Mataram yang memiliki lampu setopan atau lampu pemberhentian. Persimpangan tersebut berjumlah 7 persimpangan yaitu persimpangan Gubnur, persimpangan Kamboja, persimpangan sriwijaya, persimpangan DPD Golkar, persimpangan Yaoya, dan persimpangan Pagutan.

\section{B. Peran Kanopi Pohon Berbasis Ecologycal Lanscapedan Index}

\section{Naturalness}

Persimpangan yang dijadikan sebagai lokasi penelitian ini memiliki bentuk kanopi yang berbeda. Persimpangan Gubnur memiliki bentuk kanopi yang tertutup, persimpangan Kamboja, Yaoya dan Pagutan memiliki bentuk

\footnotetext{
${ }^{33}$ Ibid, hlm 152-154
} 
kanopi yang terbuka sedangkan persimpangan Sriwijaya dan DPD Golkar memiliki bentuk kanopi yang sedang. Bentuk kanopi dan tingkat kealamian (Index naturalness)sangat mempengaruhi kenyamanan bagi pengendara sepeda motor. Dalam pemetaan ini diambil dari radius $100 \mathrm{M}$ dari titik persimpangan.

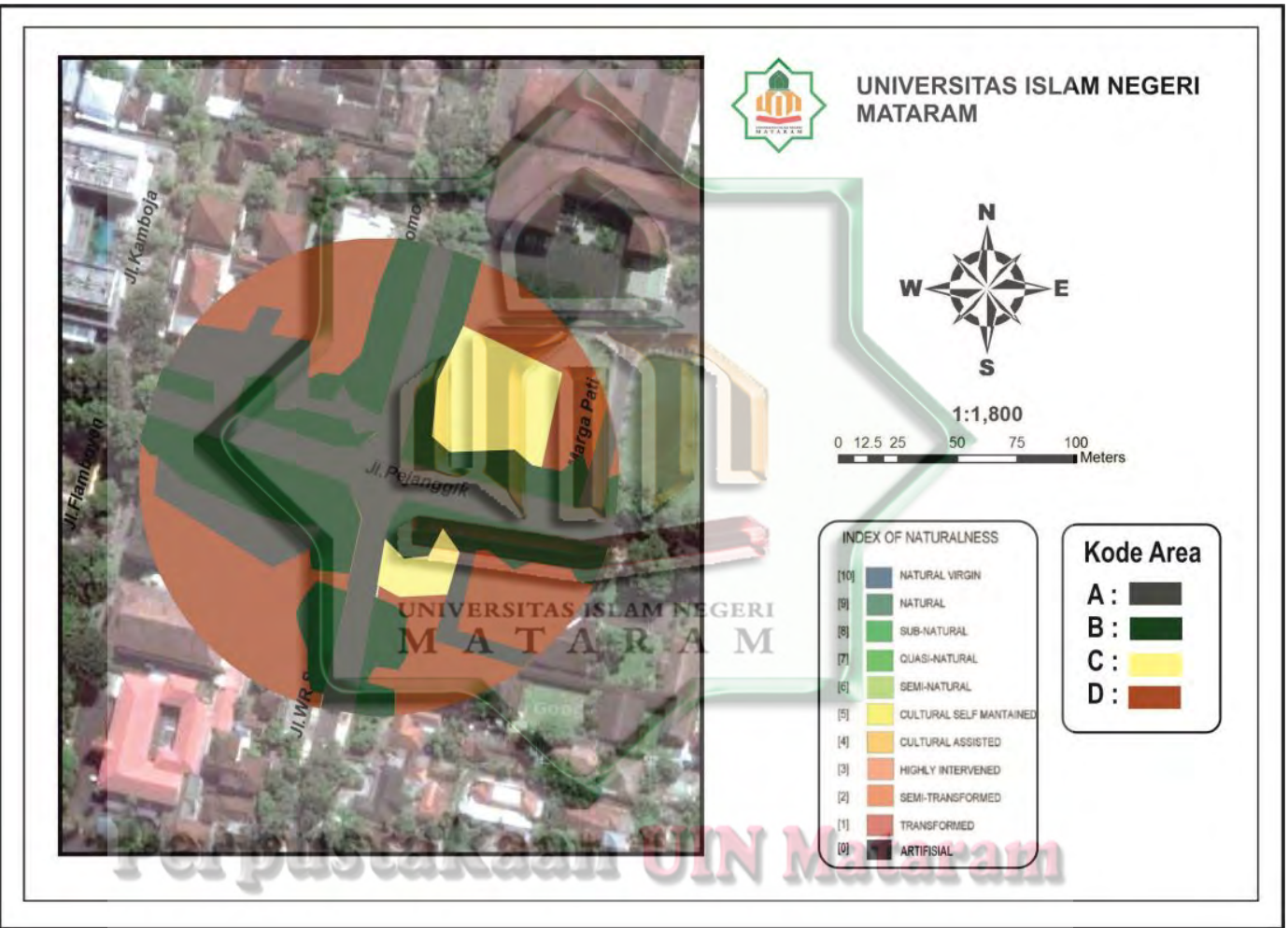

Gambar 2.1 Peta Persimpangan Gubernur

Tabel. 2.1 Index Naturalness dan LuasArea Persimpangan Gubnur

\begin{tabular}{|c|c|c|c|c|c|c|c|c|c|c|c|c|}
\hline \multirow{2}{*}{$\begin{array}{c}\text { Kode } \\
\text { Area }\end{array}$} & \multicolumn{7}{|c|}{ Index Naturalness } & $\begin{array}{c}\text { Luas } \\
\text { Area (Are) }\end{array}$ \\
\hline & $\mathbf{0}$ & $\mathbf{1}$ & $\mathbf{2}$ & $\mathbf{3}$ & $\mathbf{4}$ & $\mathbf{5}$ & $\mathbf{6}$ & $\mathbf{7}$ & $\mathbf{8}$ & $\mathbf{9}$ & $\mathbf{1 0}$ & 78.8 \\
\hline A & $\checkmark$ & & & & & & & & & & & 60.7 \\
\hline B & & & & & & & & & & $\checkmark$ & & 34,3 \\
\hline C & & & & & & $\checkmark$ & & & & & & 130.7 \\
\hline D & & $\checkmark$ & & & & & & & & & & \\
\hline
\end{tabular}




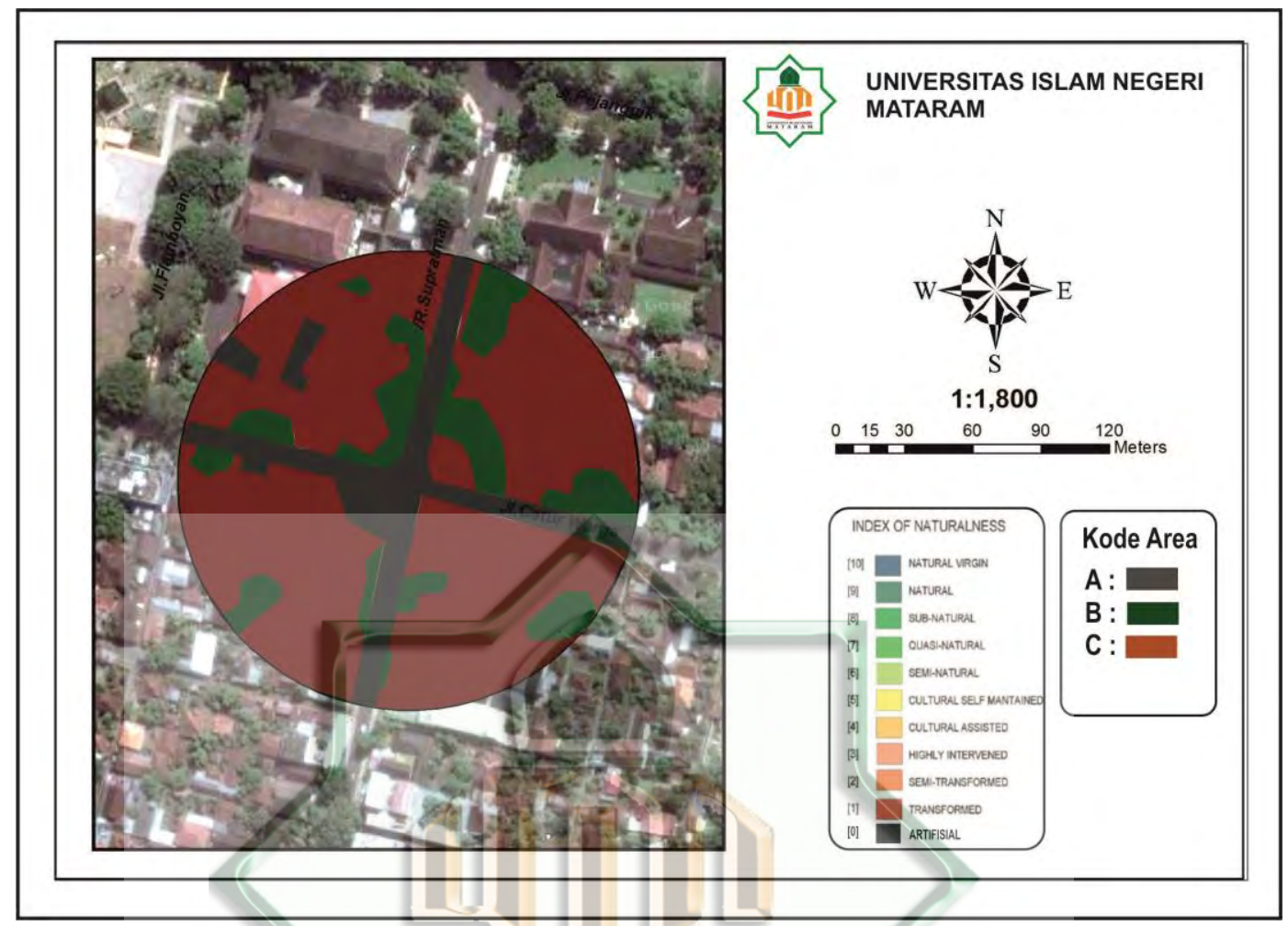

Gambar 2.2 Peta Persimpangan Kamboja

Tabel. 2.2 Index Naturalness dan LuasArea Persimpangan Kamboja

\begin{tabular}{|c|c|c|c|c|c|c|c|c|c|c|c|c|}
\hline \multirow{2}{*}{$\begin{array}{c}\text { Kode } \\
\text { Area }\end{array}$} & \multicolumn{10}{|c|}{ Undex Naturalness } & Luas \\
\cline { 2 - 10 } & $\mathbf{0}$ & $\mathbf{1}$ & $\mathbf{2}$ & $\mathbf{3}$ & $\mathbf{4}$ & $\mathbf{5}$ & $\mathbf{6}$ & $\mathbf{7}$ & $\mathbf{8}$ & $\mathbf{9}$ & $\mathbf{1 0}$ & Area (Are) \\
\hline A & $\checkmark$ & & & & & & & & & & & 57.7 \\
\hline B & & & & & & & & & & $\checkmark$ & & 36.2 \\
\hline C & & $\checkmark$ & & & & & & & & & & \\
\hline
\end{tabular}




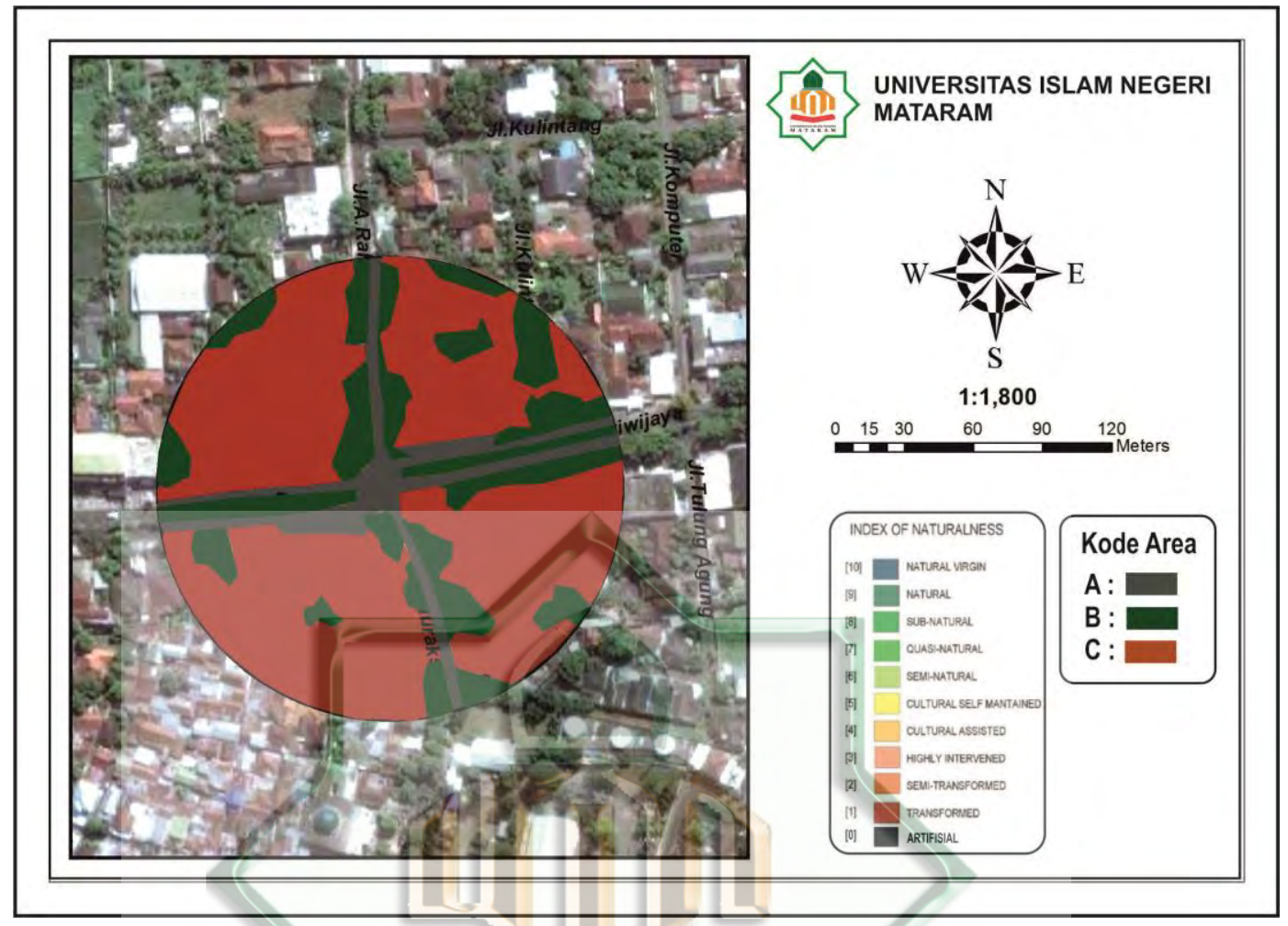

Gambar 2.3 Peta Persimpangan Sriwijaya

Tabel. 2.3 Index Naturalness dan LuasArea Persimpangan Sriwijaya

\begin{tabular}{|c|c|c|c|c|c|c|c|c|c|c|c|c|}
\hline \multirow{2}{*}{$\begin{array}{c}\text { Kode } \\
\text { Area }\end{array}$} & \multicolumn{10}{|c|}{ Index Naturalness } & \multicolumn{1}{c|}{ Luas } \\
\cline { 2 - 10 } & $\mathbf{0}$ & $\mathbf{1}$ & $\mathbf{2}$ & $\mathbf{3}$ & $\mathbf{4}$ & $\mathbf{5}$ & $\mathbf{6}$ & $\mathbf{7}$ & $\mathbf{8}$ & $\mathbf{9}$ & $\mathbf{1 0}$ & Area (Are) \\
\hline A & $\checkmark$ & & & & & & & & & & & 27.9 \\
\hline B & & & & & & & & & & $\checkmark$ & & 67.2 \\
\hline C & & $\checkmark$ & & & & & & & & & & 192.8 \\
\hline
\end{tabular}




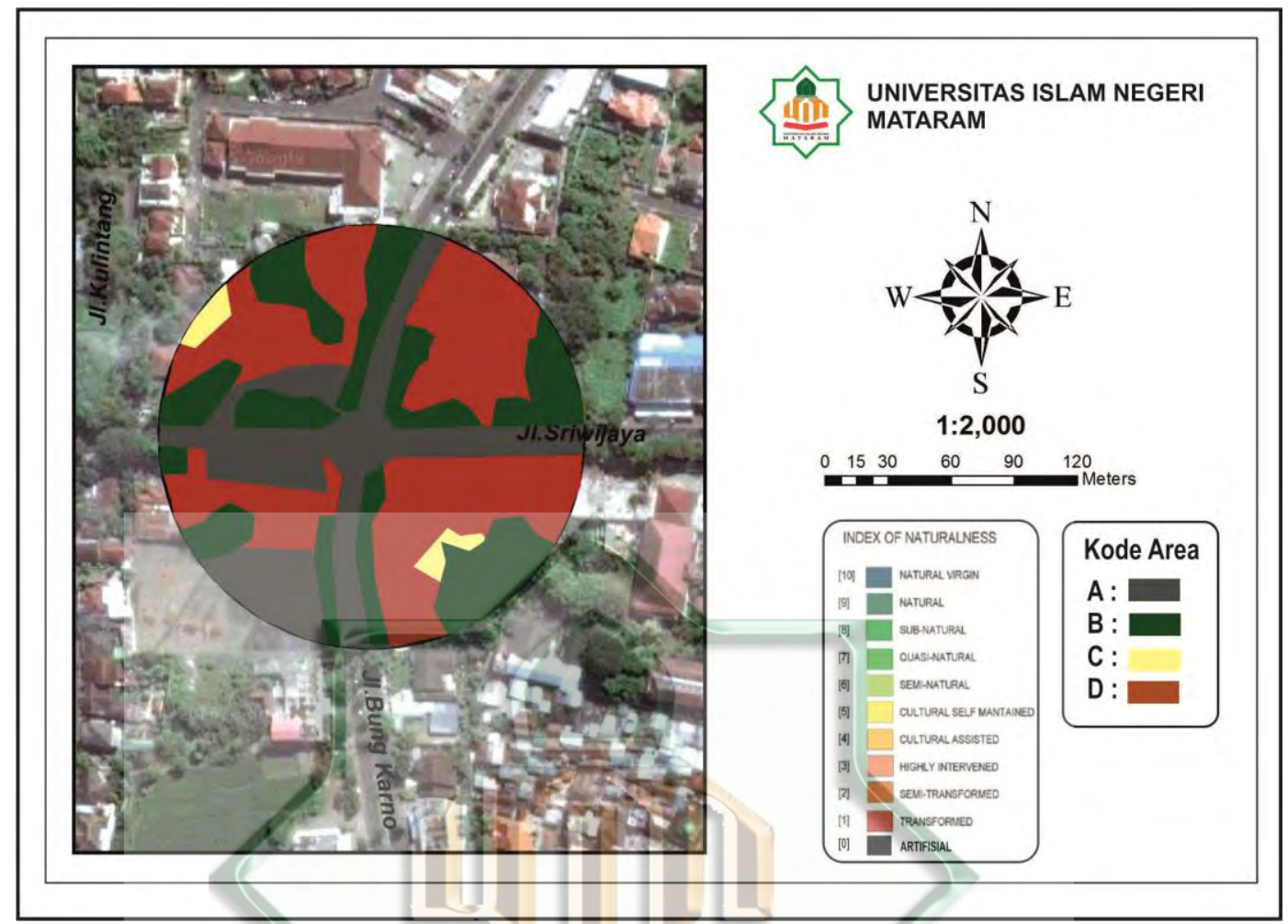

Gambar 2.4 Peta Persimpangan Golkar

Tabel. 2.4Index Naturalness dan LuasArea Persimpangan Golkar

\begin{tabular}{|c|c|c|c|c|c|c|c|c|c|c|c|c|}
\hline \multirow{2}{*}{$\begin{array}{c}\text { Kode } \\
\text { Area }\end{array}$} & \multicolumn{10}{|c|}{ Index Naturalness } & \multicolumn{1}{c|}{ Luas } \\
\cline { 2 - 11 } & $\mathbf{0}$ & $\mathbf{1}$ & $\mathbf{2}$ & $\mathbf{3}$ & $\mathbf{4}$ & $\mathbf{5}$ & $\mathbf{6}$ & $\mathbf{7}$ & $\mathbf{8}$ & $\mathbf{9}$ & $\mathbf{1 0}$ & Area (Are) \\
\hline A & $\checkmark$ & & & & & & & & & & & 98.6 \\
\hline B & & & & & & & & & & $\checkmark$ & & 81.9 \\
\hline C & & & & & & $\checkmark$ & & & & & & 17.7 \\
\hline D & & $\checkmark$ & & & & & & & & & & 162.3 \\
\hline
\end{tabular}




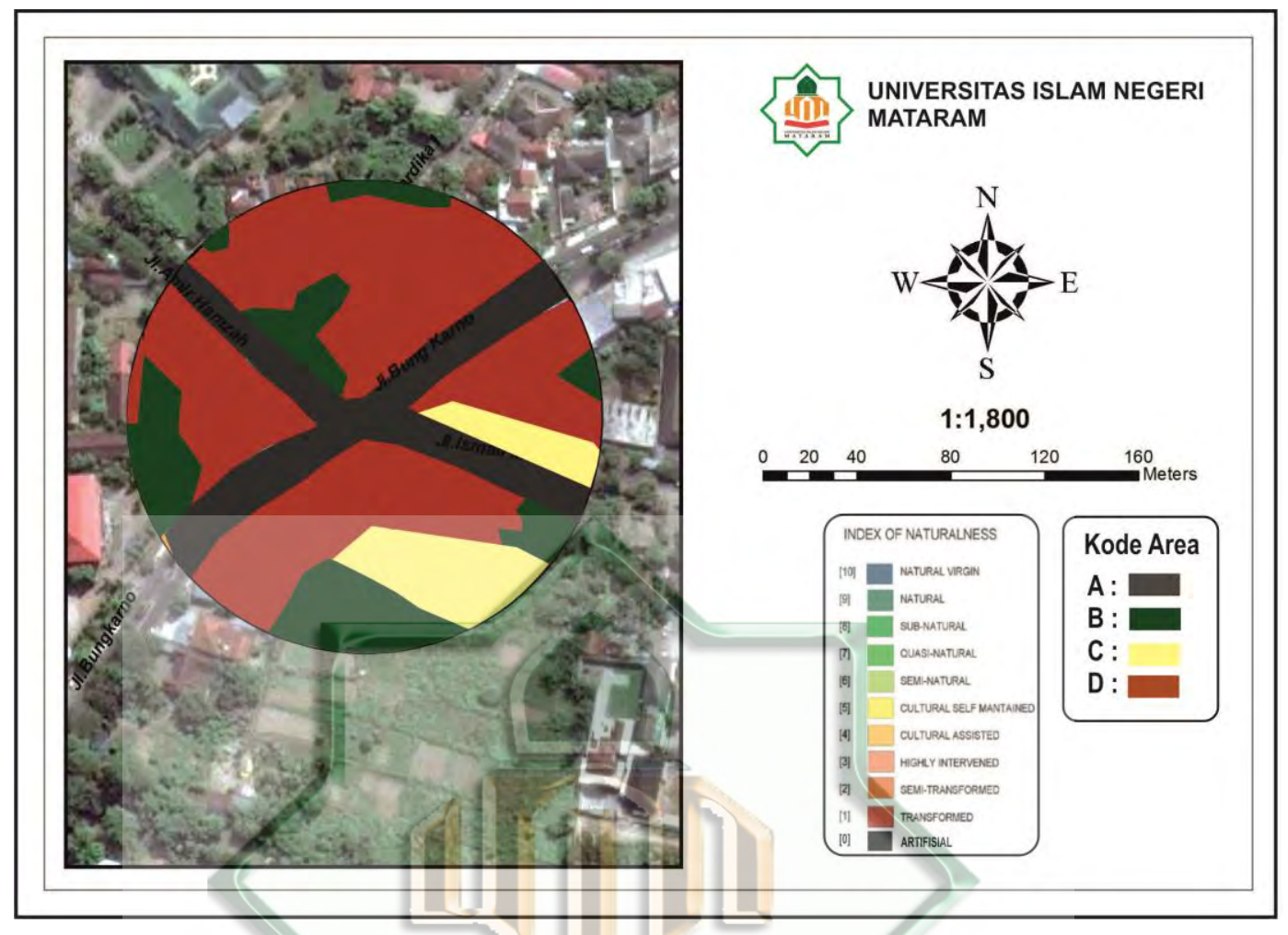

Gambar 2.5 Peta Persimpangan STMIK

Tabel. 2.5 Index Naturalness dan LuasArea Persimpangan STMIK

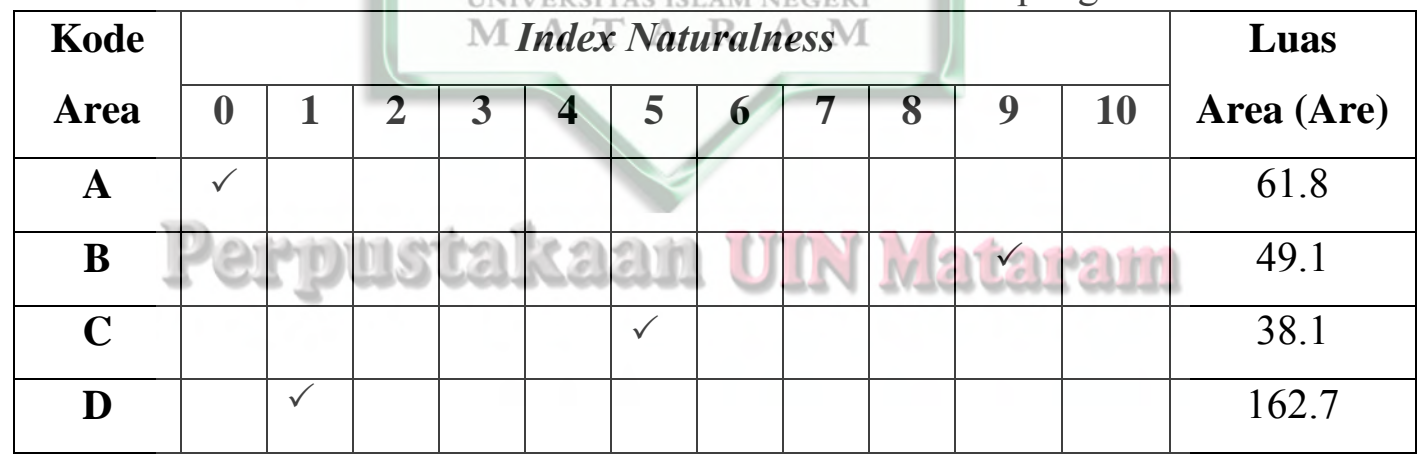




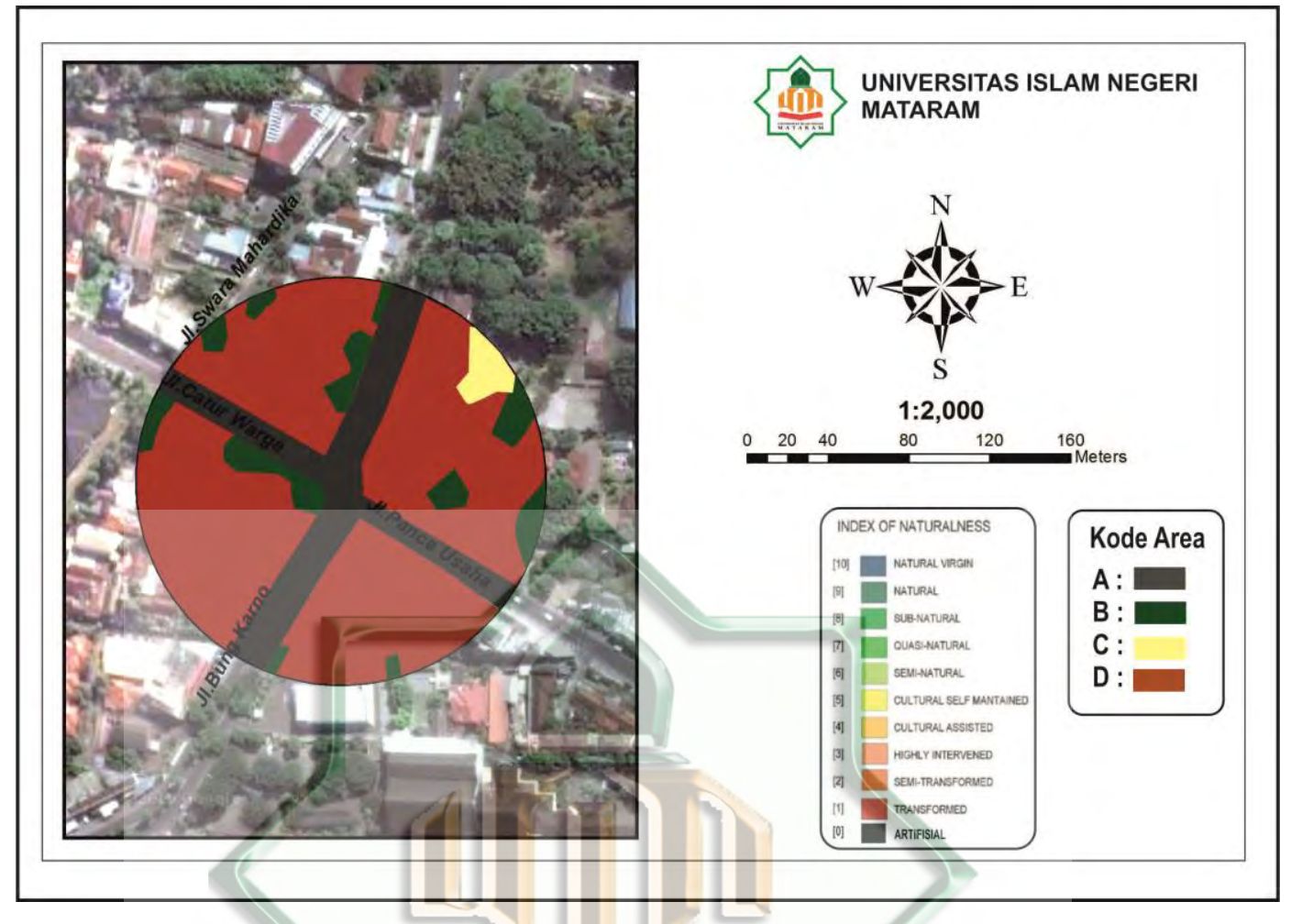

Gambar 2.6 Peta Persimpangan Yaoya

Tabel. 2.6 Index Naturalness dan LuasArea Persimpangan Yaoya

\begin{tabular}{|c|c|c|c|c|c|c|c|c|c|c|c|}
\hline \multirow{2}{*}{$\begin{array}{l}\text { Kode } \\
\text { Area }\end{array}$} & & & \multicolumn{6}{|c|}{ MIndex Naturalness } & & & \multirow{2}{*}{$\begin{array}{c}\text { Luas } \\
\text { Area (Are) }\end{array}$} \\
\hline & $\mathbf{0}$ & 1 & 2 & \begin{tabular}{|l|l|}
3 & 4 \\
\end{tabular} & 5 & 6 & 7 & 8 & 9 & 10 & \\
\hline $\mathbf{A}$ & $\checkmark$ & & & & 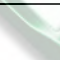 & & & & & & 58.8 \\
\hline B & $P \in$ & 21 & 118 & (18) 18 & ह1) & $(1)$ & IN & 20 & $\checkmark$ & 981 & 28.5 \\
\hline $\mathbf{C}$ & & & & & $\checkmark$ & & & & & & 7.2 \\
\hline D & & $\checkmark$ & & & & & & & & & 207.9 \\
\hline
\end{tabular}




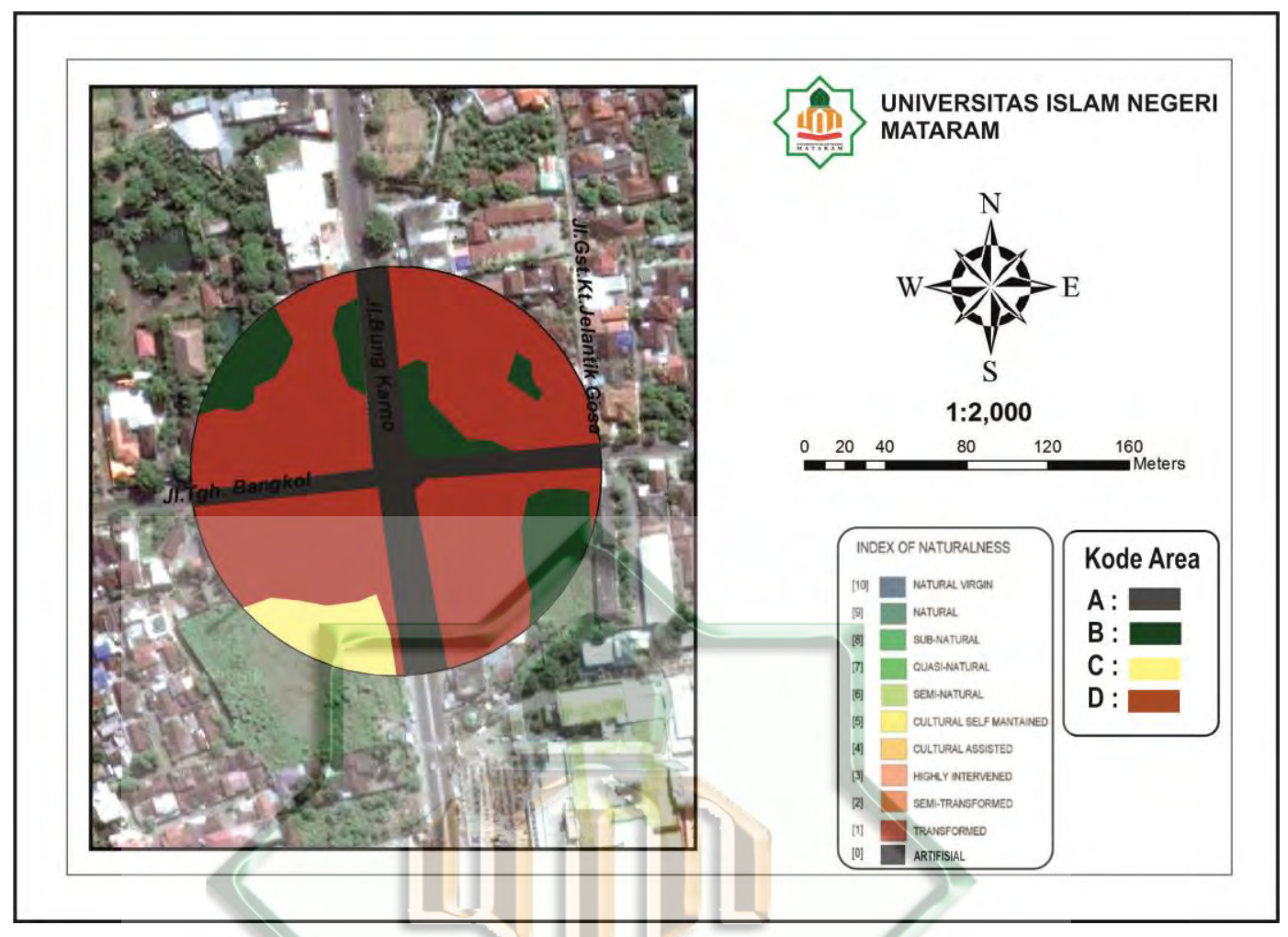

Gambar 2.7 Peta Persimpangan Pagutan

Tabel. 2.7 Index Naturalness dan LuasArea Persimpangan Pagutan

\begin{tabular}{|c|c|c|c|c|c|c|c|c|c|c|c|c|}
\hline \multirow{2}{*}{$\begin{array}{c}\text { Kode } \\
\text { Area }\end{array}$} & \multicolumn{7}{|c|}{ M Index Naturalness } & Luas \\
\cline { 2 - 10 } & $\mathbf{0}$ & $\mathbf{1}$ & $\mathbf{2}$ & $\mathbf{3}$ & $\mathbf{4}$ & $\mathbf{5}$ & $\mathbf{6}$ & $\mathbf{7}$ & $\mathbf{8}$ & $\mathbf{9}$ & $\mathbf{1 0}$ & Area (Are) \\
\hline A & $\checkmark$ & & & & & & & & & & & 54.7 \\
\hline B & & & & & & & & & & $\checkmark$ & & 46.6 \\
\hline C & & & & & & $\checkmark$ & & & & & & 18.4 \\
\hline D & & $\checkmark$ & & & & & & & & & & 186.2 \\
\hline
\end{tabular}




\section{Kenyamanan Pengendara Sepeda Motor}

Kenyamanan pengendara sepeda motor dari kuisioner yang telah di sebar di sejumlah titik persimpangan jalan penelitian. Sebanyak 20 lembar di masing-masing persimpangan yang terdiri dari 15 butir soal dengan 6 indikator.yaitu pemahaman responden terhadap arti kanopi pohon, kecukupan jumlah kanopi pohon dipersimpangan jalan kecamatan mataram, kesehatan pohon, peran pemerintah dalam menyediakan kanopi pohon, peran dan masukan masyarakat tentang kanopi pohon, dan kenyamanan pengendara sepeda motor. Dikatankan nyaman atau mencapai kreteria ketika jawaban 70\% dari total nilai masing-masing butir soal yang ada.

Tabel 2. 1 Tingkat Kenyamanan Pengendara Sepeda Motor Dipersimpangan

Kecamatan Matamarm

\begin{tabular}{|c|l|c|}
\hline No & \multicolumn{1}{|c|}{ Persimpangan } & $\begin{array}{c}\text { U Rata-rata } \\
\text { Tingakat Kenyaman }\end{array}$ \\
\hline 1 & Gubenur & $74.4 \%$ \\
\hline 2 & Kamboja & $67.9 \%$ \\
\hline 3 & Sriwijaya & $70.8 \%$ \\
\hline 4 & DPD Golkar & $73.7 \%$ \\
\hline 5 & STMIK & $67.9 \%$ \\
\hline 6 & Yaoya & $66.6 \%$ \\
\hline 7 & Pagutan & $62.5 \%$ \\
\hline
\end{tabular}

Tabel diatas menjelaskan tingkat kenyaman pengendara sepeda motor dipersimpangan jalan kecamatan Mataram. Tampak pada persimpangan kantor Gubnur memiliki tingkat kenyamanan pengendara yang paling tinggi yaitu $74.4 \%$ artinya kondisi yang dirasakan oleh pengendara motor cukup nyaman. Lain halnya pada persimpangan pagutan memiliki tingkat kenyamanan pengendara yang paling rendah yaitu $62.5 \%$.Hal ini tidak terlepas dari peran kanopi pohon 
yang berada di sekitar persimpangan tersebut. Seperti yang kita lihat dari data bahwa luasan kanopi pohon pada persimpangan kantor gubnur lebih luas dari pada luasan area kanopi yang ada di pagutan.

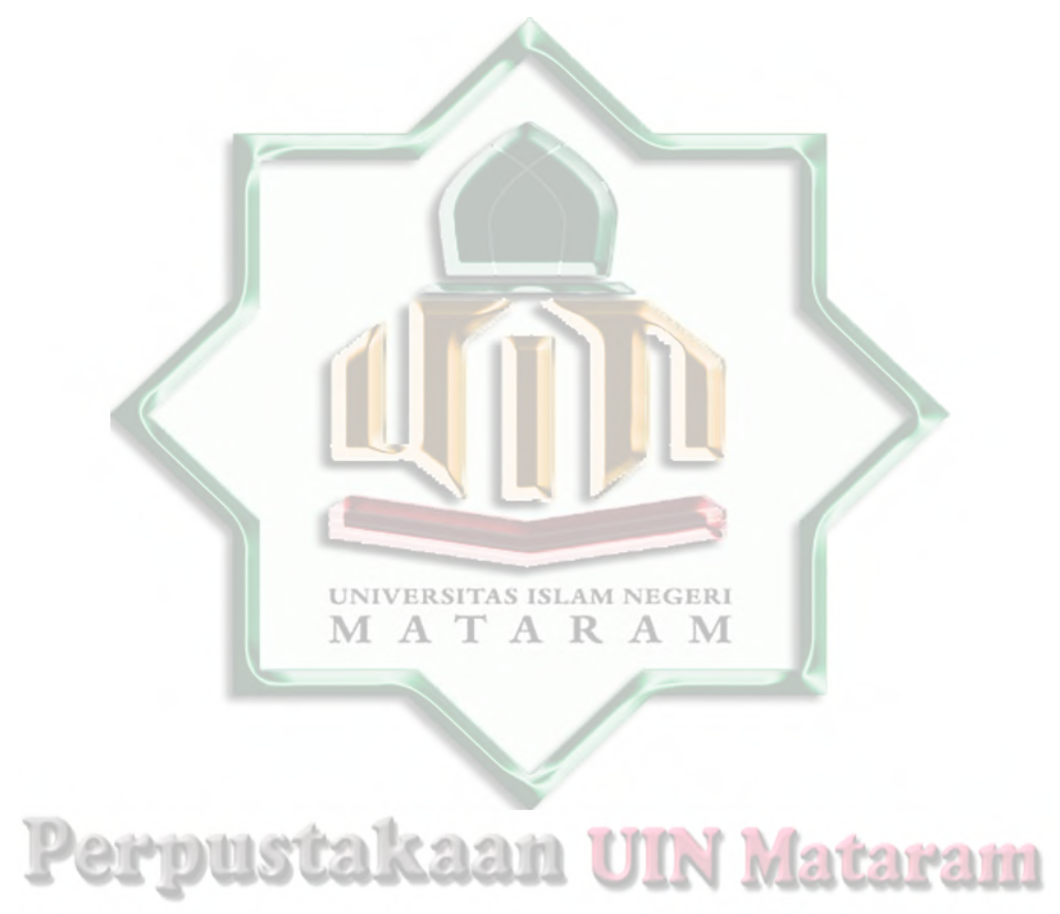




\section{BAB III}

\section{PEMBAHASAN}

\section{A. Peran Kanopi Pohon dan Index Naturalness}

Hasil penelitian ini menggunakan analisis restrospetif (Ex post facto) yaitu penelitian yang ingin mencari penyebab suatu gejala atau mengungkapakan adanya hubungan sebab akibat antara variabel yang diteliti. ${ }^{34}$ Dalam penelitian ini, peneliti menggunakan dua variabel yaitu peran kanopi pohon berbasis ecological landscape dan index naturalness sebagai ecosystem services dan kenyamanan pengendara sepeda motor dipersimpangan jalan kecamatan Mataram.

Peneliti memperoleh data respondens dari kuisioner yang telah disebarkan (kuisioner berisi beberapa indikator yang harus di jawab oleh UNIVERSITAS ISLAM NEGERI korespondens diantaranya yaitu pemahaman responden terhadap arti kanopi pohon, kecukupan jumlah kanopi pohon dipersimpangan jalan kecamatan mataram, kesehatan pohon, peran pemerintah dalam menyediakan kanopi pohon, peran dan masukan masyarakat tentang kanopi pohon, dan kenyamanan pengendara sepeda motor) kepada para pengendara motor di setiap persimpangan yang ada di kecamatan Mataram dan memperoleh tingkat kealamian (index naturalness)dari sofwer ArcGis10 dan Google eart untuk menentukan titik koordinat lokasi penelitian. Sehingga dengan adanya index naturalness dan data tingkat kenyaman pengendara sepeda motor peneliti

\footnotetext{
${ }^{34}$ Sadjaja, Albertus herianto. 2006. Panduan penelitian. Jakarta : prestasi oustaka. Hal. 112.
} 
bisamengetahui peran kanopi pohon terhadap kenyamanan pengendara sepeda motor terutama di persimpangan jalan kecamatan Mataram.

Terbuka, sedang dan rindang merupakan jenis kanopi pohon.Terbuka yang berarti memiliki intensitas cahaya yang banyak menuju permukaan, sedang yang berarti kisaran intensitas cahaya yang berada dalam rata-rata dan rindang yang berarti kisaran dibawah rata-rata semakin banyak rindang kanopi maka semakin membuat suasana nyaman bagi pengendara. Kanopi pohon tidak hanya memberi suasana nyaman dan memberi mamfaat baik bagi pengendara sepeda motor namun dapat juga memberi manfaat bagi warga perkotaan. ${ }^{35}$

Sebuah setudi literatur mengatakan bahwa dengan adanya kanopi pohon dapat membuat tata ruang kota yang indah sehingga dapat dinikmati oleh semua orang bukan hanya pengedara sepeda motor saja. Bahkan bisa menjamin orang disekitarnya akan menghabiskan waktunya di luar rumah sambil menikmati pemandangan kanopi pohon yang ada disekitarnya. Sehingga dengan hadirnya kanopi pohon dapat mengurangi tingkat kriminalitas bersamaan dengan meningkatnya masyarakat yang memilih berkegiatan di luar rumah.Lain halnya dengan ketika para criminal melihat kondisi lingkungan yang sepi karena masyarakatnya yang memilih untuk diam dirumah, karena sebuah tindakan criminal biasanya terjadi ketika ada sebuah peluang untuk melakukannya. $^{36}$

\footnotetext{
${ }^{35}$ Greene, Chistopher S. Canopy of advantage: Who benefit most from city trees?. Urban Forest Research \& Ecological Disturbance (UFRED) Grup, Toronto: Canada. 2018

${ }^{36}$ Troy, Austin, dkk. The relationship between tree canopy nd crime rates cross an urbnrural gradient in the greater Baltimore region. Landscape and Urban Planning: Unites state. 2012.
} 
Peranan pohon di lingkungan perkotaan yaitu, meningkatkan kualitas udara, peredam kebisingan, menurunkan suhukota, memperindah kota, pelestarian air tanah, meningkatkan keselamatan berlalu lintas. ${ }^{37}$ Faktor kenyamanan dalam berkendara menjadi sangat penting untuk perhatikan supaya tidak terjadi gangguan dalam proses berkendara, ada banyak faktor yang mempengaruhi kenyamanan dan kesetabilan dalam berkendara, salah satunya akibat paparan sinar matahari lagsung. Akibat permasalahan tersebut banyak terjadi pelanggaran terhadap rambu-rambu lalulintas pada saat berhenti di area persimpangan jalan yang memiliki traffic ligh, seperti menerobos lampu merah, berhenti tidak pada lajur jalan yang sudah ditentukan dan lain sebagainya. Untuk itu kenyamanan dalam berkendara sangat diperlukan mengingat hal ini bagian penting bagi pengendara untuk mampu berkonsentrasi saat berada di jalan raya. ${ }^{138}$ Sehingga dengan kehadiran kanopi pohon terutama di jalur transportasi akan mampu memberikan kenyamanan bagi pengendara terutama pengendara sepeda motor.

\section{B. Hasil Penelitian}

Tingkat kealamian (index naturalness) pada suatu daerah sangat berhubungan dengan baigamana kenyamanan khususnya bagi pengendara sepeda motor. Dengan tingkat kealamian yang tinggi maka akan memberikan rasa yang lebih nyaman pula hal ini terbukti pada wilayahpersimpangan kantor

\footnotetext{
${ }^{37}$ Ekindo Vanesah Sitinjak. "Status Kesehatan Pohon Pada Jalur Hijau Dan Halaman Parkir Universitas Lampung”. (skripsi, fakultas pertanian, Univeritas lampung, bandar lampung, 2016) Hlm: 6-9.

${ }^{38}$ Chika Oliviani dan Harus Laksana Guntur. 2014. Analisa Kenyamanan Kendaraan Roda Duadengan Pemodelan Pengendara sebagai Multi-Sistem. Jurnal Teknik Pomits. Vol. 3, Hal. 5760
} 
Gubnur dengan titik koordinat $8^{0} 582^{\text {ee }} 868^{\prime \prime}$ LS dan $116^{0} 108^{\circ e} 750^{\prime \prime}$ BT bentuk kanopi pohon yang terbuka.Wilayah persimpangan dari radius $100 \mathrm{M}$ dari titik persimpangan terdiri dari terbagi menjadi beberapa area yaitu area natural atau alami dengan kategori index 9 memiliki luas 60.7 Are, Area kategori index 0 seluas 78.8 Are, area kategori index 5 memiliki luas 34.3 Are dan kategori 1 memiliki luas area 130.7 Are. Tingkat kenyaman yang pengendara rasakan pada persimpangan ini cukup baik yaitu $74.4 \%$. Pada persimpangan Kamboja dengan titik koordinat $8^{0} 584^{\text {ee }} 476^{\prime \prime}$ LS dan $116^{0} 108^{\text {ee } 379^{\prime \prime}}$ BT, bentuk kanopi pohon yang terbuka dengan luas area kategori index naturalness 0 yaitu 78.8 Are, kategori 9 memiliki luas 60.7 Are, kategori 5 memiliki luas 34.3 Are dan area kategori 1 memiliki luas 130.7 Are. Dan tingkat kenyamanan pengendra sepeda motor yaitu $67.9 \%$.Persimpangan Sriwijaya dengan titik koordinat $8^{0} 594^{\text {ee }} 814^{\prime \prime}$ LSdan $116^{0} 107^{\circ} 935^{\prime}$ " BT dengan bentuk kanopi terbuka. Memiliki luar area kategori 0 yaitu 27.9 area kategori 9 yaitu 67.2 dan area kategori 1 yaitu 192.8. tingkat kenyaman pengendara yaitu $70.8 \%$.

Pada persimpangan Golkar dengan titik koordinat $8^{0} 594^{e e} 319^{\prime \prime}$ LS dan $116^{0} 112^{\text {ee }} 807$ " BT memiliki bentuk kanopi terbuka dimana area kategori 0 memiliki luas 98.6 are, kategori 9 yaitu 81.9 are, kategori 5 yaitu 17.7 are dan kategori 0 yaitu 162.3 are dengan tingkat kenyamanan pengendara $73.7 \%$. Persimpangan STMIK Bumi Gora dengan tirik koordinat $8^{0} 590^{\text {ee }} 865^{\prime \prime}$ LSdan $116^{0} 115^{\text {ee }} 011^{\text {'BT }}$ yang memiliki bentuk kanopi terbuka dengan luas area kategori 0 yaitu 61.8 are, kategori 9 yaitu 49.1 are, kategori 5 yaitu 38 are dan kategori 0 yaitu 162.7 dengan tingkat kenyamanan yang dirasakan oleh 
pengendara sepeda motor yaitu 67.9\%. Persimpangan Yaoya dengan titik

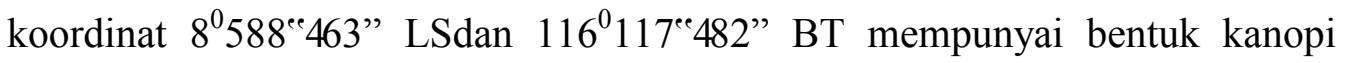
yang terbuka dengan luas area kategori 0 yaitu 58.8 are, kategori 9 yaitu 28.5 are, kategori 5 yaitu 7.2 are, dan kategori 1 yaitu 207.9 are dengan tingkat kenyamanan $66.6 \%$. Pada Persimangan Pagutan dengan titik koordinat $8^{0} 598^{\text {‘e} 525 " ~ L S d a n ~} 116^{0} 113^{\text {‘e}} 216^{\prime \prime B T}$ memiliki bentuk kanopi yang terbuka dengan luar area kategori 0 yaitu 54.7 are, kategori 9 yaitu 46.6 are, kategori 5 yaitu 184 are dan kategori 1 yaitu 186.2 are dengan tingkat kenyamanan pengendara sepeda motor yang dirasakan yaitu $62.5 \%$. Pada dasarnya ecosystem services menyediakan pelayanan secara langsung atau tidak langsung berupa kontribusi untuk meningkatkan kesejahteraan manusia. Dari hasil peneltian ini menunjukkan bahwa semakin tinggi tingkat kealamian (index naturalness) maka semakin tinggi tingkat kenyamaan yang dirasakan oleh pengendara sepeda motor di kecamatan mataram.

\section{Solusi yang Peneliti Tawarkan}

Adapun solusi yang saya tawarkan kepada responden dalam kuisioner berupa kanopi pohon.Kanopi pohon (tree canopy) merupakan lapisan dari dedaunan, cabang dan batang dari pepohonan yang menutupi permukaan tanah ketika dilihat dari bagian atas. Selain itu kanopi pohon merupakan bagian dari tumbuhan yang mampu menutupi bagian permukaan tanah dari cahaya matahari. Kanopi pohon menyediakan berbagai manfaat untuk kebutuhan manusia, diantaranya: meningkatkan kualitas air, menyimpan energi, mengurangi paparan cahaya matahari, mereduksi polusi udara, meningkatkan 
nilai estetika lingkungan, meyediakan habitat bagi organisme lain dan memfasitlitasi peluang pembelajaran dan kehidupan social. ${ }^{39}$

Sedangkan pohon merupakan jenis tumbuhan berkayu yang mampu tumbuh besar dengan memanfaatkan hasil-hasil emisi buangan berupa karbon sebagai sumber pembentukan energi dan menghasilkan $\mathrm{O}_{2}$ melalui fotosintesis. Selain itu, pohon juga bermanfaat sebagai naungan atau kanopi dari pancara panas cahaya matarahari sehingga kanopi pohon memberikan rasa nyaman bagi manusia atau hewan dalam melakukan aktifitas disiang hari. ${ }^{40}$ Sehingga dengan adanya kanopi berupa pohon, dapat kenyamanan bagi penedendara bermotor saat berada di lampu setopan di setiap persimpangan jalan Kecamatan Mataram.

Kanopi pada umumnya tidak hanya berupa pohon atau tumbuhan lainnya. Kanopi dapat berupa bangunan tinggi, atap rumah, bagasi mobil dan lain-lain dan biasanya dikelompokkan ke dalam kanopi sintesis atau buatan yang dimana hanya memberi pelayanan ekosistem berupa tempat teduh dan bisa pula sebagai penataan ruang. Lain halnya dengan kanopi alami selain yang disebutkan sebelumnya, dapat pula mengurangi temperatur udara melalui siklus hidrologi dengan cara memperbanyak kecepatan angin. ${ }^{41}$ Sehingga dengan hadirnya kanopi di persimpangan jalan, selain para pengendara

\footnotetext{
${ }^{39}$ National Researcher Council. A Report on Existing and Possible Tree Canopy in the City of Charlotte and Mecklenburg County, NC. Washington, DC: The National Academies Press. 2014

${ }^{40}$ Michael Oloyede Alabi dan Enete Ifeanyi Christian. 2013. Street Tree Canopy Cover Variation Effects on Temperature in Lokoja, Nigeria. Journal of Agriculture and Environmental Sciences, Vol. 2 No. 2. Hal. 25-31

${ }^{41}$ Loughhner P, Chistopher. Roles of Urban Tree Canopy and Buildings in Urban Heat Island Effect: Parameterization and Preliminary Result. (Manuscript, Departement of Atmospheric and Oceanic Science, University of Myrland, Collage Park, Myrlad, 2011).
} 
mendapatkan kenyamanan dalam berkendaraan, polusi yang disebabkan oleh kendaraan dapat diperkecil dengan mengasimilasi gas buang kendaraan bermotor serta membentuk keseimbangan ekosistem.Hal ini terbukti dari hasil kuisioner penelitian ini yang dimana koresponden merasakan ketidaknyamanan dalam mengendara karna kurangnya kanopi pohon atau index naturalness yang rendah dari suatu wilayah. Sehingga solusi kanopi pohon dalam meningkatkan kenyaman pengendara sepeda motor dapat dijadikan acuan bagi masyarakat dan pemerintah dalam meningkatkan kenyamanan.

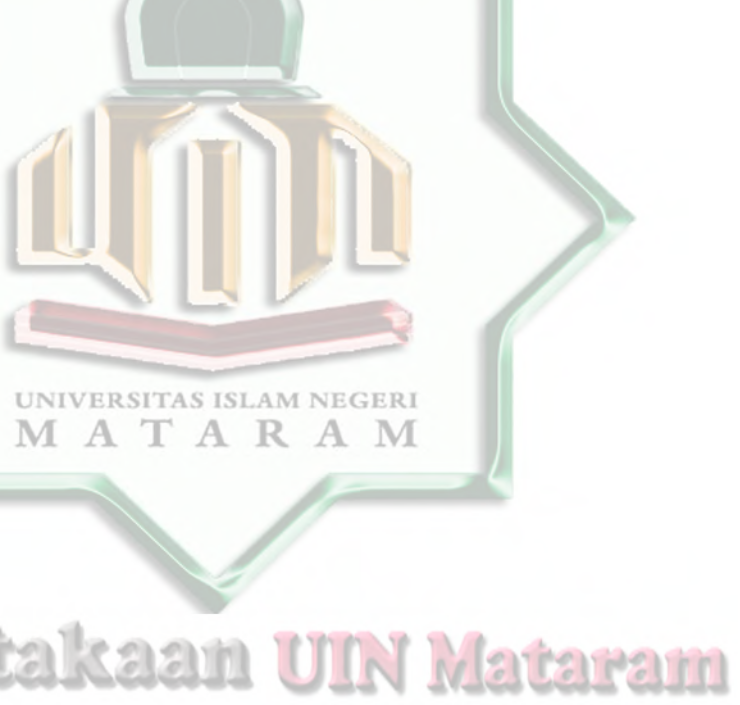




\section{BAB IV}

\section{PENUTUP}

\section{A. Kesimpulan}

1. Hasil penelitian ini memberikan sebuah gambaran dengan adanya kanopi pohon dan index naturalness yang cukup memberikan pengaruh terhadap kenyamanan pengendara sepeda motor. Secara keseluruhan bentuk kanopi pohon yang ada di persimpangan jalan kecamatan mataram sebagian adalah terbuka dan index naturalness yang belum mencukupi.

2. Pada persimpangan jalan kantor gubnur, Sriwijaya, dan Golkar memiliki kategoriindex naturalnessyang cukup baik sehingga memberikan kenyamanan kepada pengendara sepeda motor yang baik pula yaitu dengan tingkat kenyamanan $74.4 \%, 70.8 \%$ dan $73.7 \%$. Lain halnya dengan persimpangan jalan Kamboja, ${ }^{\mathrm{A}}$ STMIK, Yaoya dan Pagutan, dengan kurangnya kehadiran kanopi pohon atau kategori index naturalness yang rendah makan akan memberikan rasa kenyamanan yang rendah pulakepada pengendara sepeda motor. Hal ini terbukti di persimpangan ini dimana tingkat kenyamanannya yang rendah yaitu, 67.9 $\%, 67.9 \%, 66.6 \%$ dan $62.5 \%$. Sehingga Semakin tinggi kategori index naturalness pada suatu wilayah maka semakin tinggi tingkat kenyamanan yang dirasakan oleh pengendara sepeda motor pada wilayah tersebut. 


\section{B. Saran}

Pengkajian tentang kanopi pohon dapat dijadikan sebagai refrensi bagi pemerintah untuk mengelola suatu wilayah dan khusus bagi mahasiswa jurusan IPA Biologi perlu adanya pengkajiandan penelitian jenis kanopi pohon dan sebaran yang cocok untuk dijadikan sebagai kanopi khususnya di jalur tansportasi.

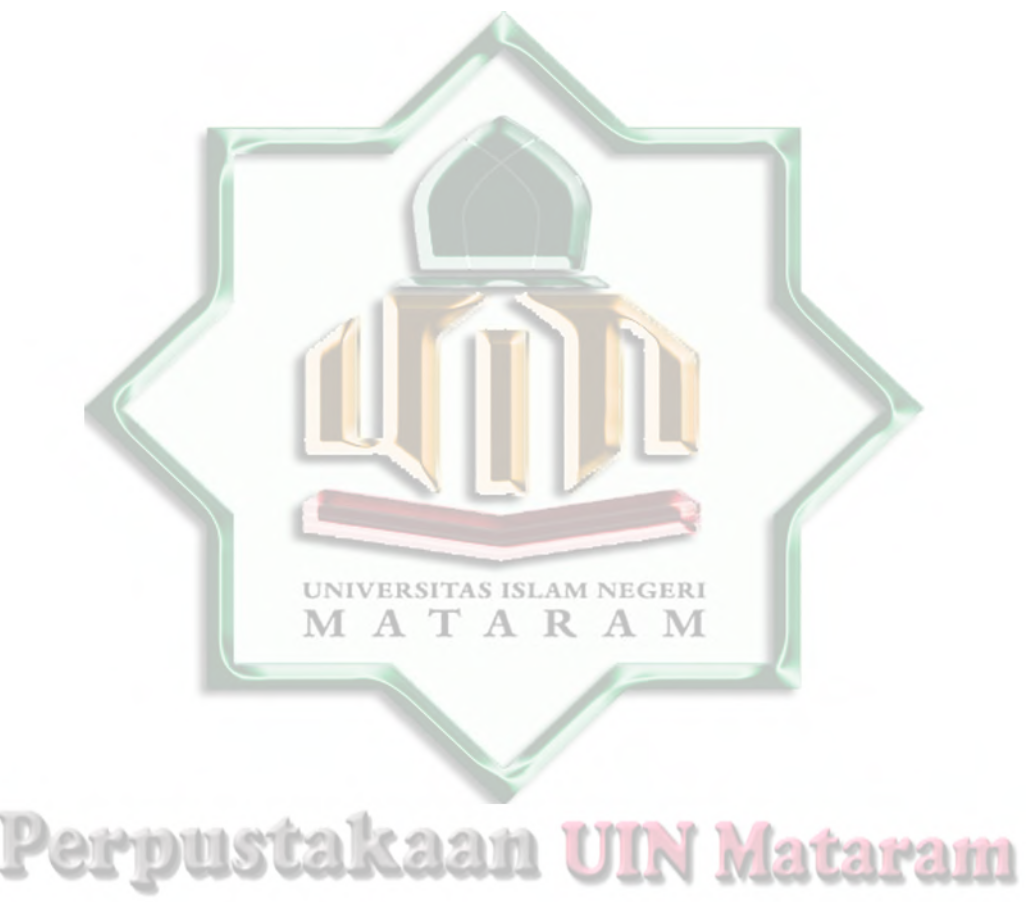




\section{DAFTAR PUSTAKA}

Bapeda dan BPS Kota Mataram. 2012. Mataram dalam Angka Tahun 2012. Mataram. BPS KotaMataram. Hal. 04.

Didier Bourguignon. 2015. Ecosystem Services Valuing Our Natural Capital. European Parliamentary Research Service.

Ekindo Vanesah Sitinjak. "Status Kesehatan Pohon Pada Jalur Hijau Dan Halaman Parkir Universitas Lampung". (skripsi, fakultas pertanian, Univeritas Lampung, Bandar Lampung, 2016) Hlm: 6-9.

Humaidi, M. Artikrl Pohon Pelindung Jalan di Kotamadya Mataram (skripsi FKIP: UNRAM, 2003) hal. 01.

Hidayat, I. W. (2010). Kajian Fungsi Ekologi Jalur Hijau Jalan Sebagai Penyangga Lingkungan pada Tol Jagorawi (Study of the Ecological Function of Roadside Greenery as Environmental Buffer on Jagorawi Highway).Jurnal Manusia dan Lingkungan, 17(2), 124-133.

Juliansah Noor.2012.Metodologi penelitian.Jakarta:Kencana (Hlm: 148).

Hanafri, K. S. (2011). Analisis Manfaat Kanopi Pohon Dalam Mereduksi Polutan Udara Menggunakan Program Citygreen Di Jalan Raya Padjajaran, Kota Bogor.

Loughner, C. P., Allen, D. J., Zhang, D. L., Pickering, K. E., Dickerson, R. R., \& Landry, L. (2012). Roles of urban tree canopy and buildings in urban heat island effects: Parameterization and preliminary results. Journal of Applied Meteorology and Climatology, 51(10), 1775-1793.

Machado, A. (2004). An index of naturalness.Journal for nature conservation, 12(2), 95-110.

Michael Oloyede Alabi dan Enete Ifeanyi Christian. 2013. Street Tree Canopy Cover Variation Effects on Temperature in Lokoja, Nigeria. Journal of Agriculture and Environmental Sciences, Vol. 2 No. 2. Hal. 25-31.

National Researcher Council. 2014. A Report on Existing and Possible Tree Canopy in the City of Charlotte and Mecklenburg County, NC. Washington, DC: The National Academies Press.

Prastiyo, P., Ismail, M., Basith, A., \& Sazali, M. (2016).Studi Deskripsi Hubungan Antara Naturalness Index dan Biodiversity Indexdengan Iklim Mikro pada Kelurahanjatimulyo, Mojolangu, dan Mergosonodi 
Kota Malang Berbasis Ecologicallandscape.Biota: Jurnal Pendidikan Biologi, 9(1).

Sadjaja,Albertus herianto.2006.Panduan penelitian.Jakarta:Prestasi oustaka.(Hlm.112).

Setyowati, D. L. (2008).Iklim Mikro dan Kebutuhan Ruang Terbuka Hijau di Kota Semarang (The Micro Climate and The Need of Green Open Space for The City of Semarang).Jurnal Manusia dan Lingkungan, 15(3), 125-140.

Sitawati dan Agus Suryanto. 2012. Model Keterpaduan Pohon dalam Menentukan Indeks Kenyamanan Ruang Terbuka Hijau (RTH). Laporan Akhir Hasil Penelitian Unggulan Perguruan Tinggi-Hibah Bersaing (Tahun Ke-1) Tahun Anggaran 2012. DIPA Universitas Brawijaya.

Sugiono. 2016.Metode penelitian. Bandung: Alfabeta. Hlm: 38.

Sutrisno Hadi. 1979. statistic Jilid II. Yayasan Penerbit Fakultas Psikologi. Jakarta. UGM.

Wahyunah, W., Krisdianto, K., Kadarsah, A., \& Rahmani, D. R. (2016).Variasi Kanopi dan Porositas Pohon di Ruang Hijau Pribadi Permukiman Baru Kelurahan Loktabat Utara Kota Banjarbaru Canopy and Porosity Variation On The Trees In The Private Green Space In Loktabat Utara Banjarbaru. Jukung (Jurnal Teknik Lingkungan), 2(2). 


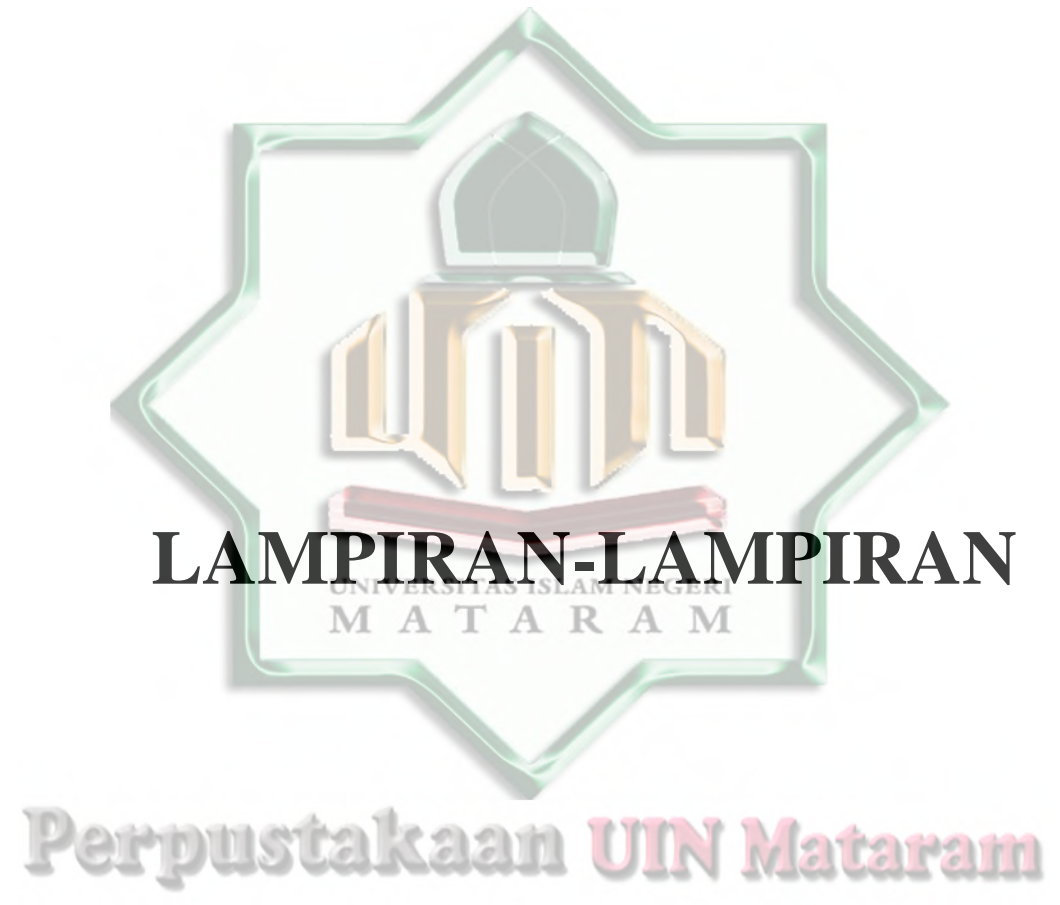




\section{Lampiran I}

\section{KUESIONER}

\section{Respon Pengendara Bermotor Terhadap Peran Kanopi Pohon Sebagai ecosystem service \\ di Wilayah Persimpangan Jalan Kecamatan Mataram}

\section{Identitas Responden}

Nama

Jenis Kelamin $\quad:$ L / P

Umur

Pekerjaan

Alamat

Petunjukpengisian

a. Berilahtandasilang

(X) padabeberapapernyataan

yang

sesuaidenganpengetahuandankondisi yang Andarasakan.

b. Andabolehmenyilang 1, 2, 3, dan 4 darijumlahpernyataan yang ada.

1. Apakahtransportasi (sepeda motor) sangatpentingbagianda?
a. Sangatmembantudalamberaktivitas A M
b. Meghindarikemacetan
c. Lebihiritdanmudahjikadibandingkandengan yang lain
d. Tidakmemberikanpolusipadalingkungan

2. Apakahpohon peneduh (kanopi

pohon)sangatmemberikankenyamananbagipengendarasepeda motor?
a. Memberikana rasa sejuk
b. Memberikannaunganterhadappengendara
c. Mengurangipolusiudara
d. Mengurangipelanggaranlampusetopan

3. Bagaimanakah kondisi pohon peneduh (kanopi pohon) di persimpangan jalan Kota Mataram?
a. Memberikankenyamanan
b. Menaungipersimpanganjalan
c. Terdapat di setiappersimpangan 

d. Tidakmembahayakanpengendara

4. Bagaimana suhu udara pada siang hari di persimpangan jalan Kota Mataram?
a. Panas
b. Merasatidaknyaman
c. Aroma yang menyengat
d. Polusi

5. Apa yang Anda rasakan jika berhenti pada lampu setopan yang tidak memiliki banyak pepohonan di Kota Mataram?
a. Panas
b. Merasatidaknyaman
c. Aroma yang menyengat
d. Polusi

6. Apa yang Anda rasakan jika berhenti pada lampu setopan yang memiliki banyak pepohonan di Kota Mataram?
a. Sejuk
b. Nyaman
c. Sabarmenunggu
MVERSITAS ISLAM NEGERI
d. Tidakbanyakpolusi

7. Manakah yang lebih nyaman dirasakan keberadaan kanopi (naungan) dari pohon atau kanopi buatan sebagai peneduh di persimpangan jalan Kota Mataram?
a. Lebihnyamandengannaunganpohon
b. Naunganpohonmemberikanudarasegar
c. Kanopibuatantidakmengurangi rasa panas
d. KanopibuatantidakbisamengurangiPolusi

8. Bagaimanakah sikap anda jika menunggu pemberhentian lampu setopan jika berada di bawah naungan (kanopi) dari pohon?
a. Sabarmenunggu
b. Tidaktergesa-gesa
c. Tidakmeneroboslampusetopan
d. Tertib di posisijalan 
9. Seberapa sering Anda menerobos lampu setopan di persimpangan jalan Kota Mataram?
a. Disaatmerasakepanasan
b. Disaatkondisi yang mendesak
c. Disaattidaktahankarenapolusiudara
d. KetikaKondisijalansepi

10. Perlukah pemerintah meningkatkan keberadaan naungan (kanopi) dari pohon untuk peneduh pengguna sepeda motor di persimpangan jalan Kota Mataram?
a. Sangatperluuntukmemberikankenyamanan
b. Untukmengurangipelanggaran
c. Mengurangipolusiudara
d. Untuk keseimbaganRuang Taman Terbuka (RTH)

11. Apakah yang Anda pahami tentang kanopi pohon?
a. Mengetahuimaksuddarikanopipohon
b. MengetahuiManfaatdarikanopipohon
c. MengetahuiDampakdaritidakadanyakânopipohon
d. Mengetahuicarauntukmeningkatkankeberadaankanopipohon

12. Bagaimanaresponandaketikamelihatpengendara lain meneroboslampusetopan?
a. Menyadaribahwaperilaku yang salah
b. Memahamikarenakondisi yang tidaknyaman
c. Memberikanpemahamankepada orang lain supayatidakmelakukanhalyang sama
d. Tidakmau tau

13. Apakahkanopipohon di persimpanganjalankecamatanmataramsudahmemadai?
a. Sudahadakanopipohon
b. Terdapat di semuapersimpanganjalan
c. Kanopipohon terawatt olehpihakpemerintah
d. Adanyatindaklanjutdaripemerintah 
14. Apakah yang akanterjadijikakanopipohontidakadalagi di persimpanganjalan?

a. Pulusiudara yang yangtidakterkendali

b. Suhupanasakanmeningkat

c. Ketidaknyamanan yang dirasakanolehpengendara

d. Memicupenerobosan lampusetopan

15. Bagaimanakahharapanandakedepannyamengenaikondisikanopipohon yang berdadipersimpanganjalankecamatanmataram?

a. Pemerintahlebihmemperhatikankondisipohon yang ada

b. Pemerintahselalumemberikanpemahamanbagaimanapentingnyapohonbagi kehidupan

c. Seluruhaspekmerasabertanggungjawabdalammenjagalingkungan

d. Bisasalingmemperingatidalammenjagadanmerawatlingkungan

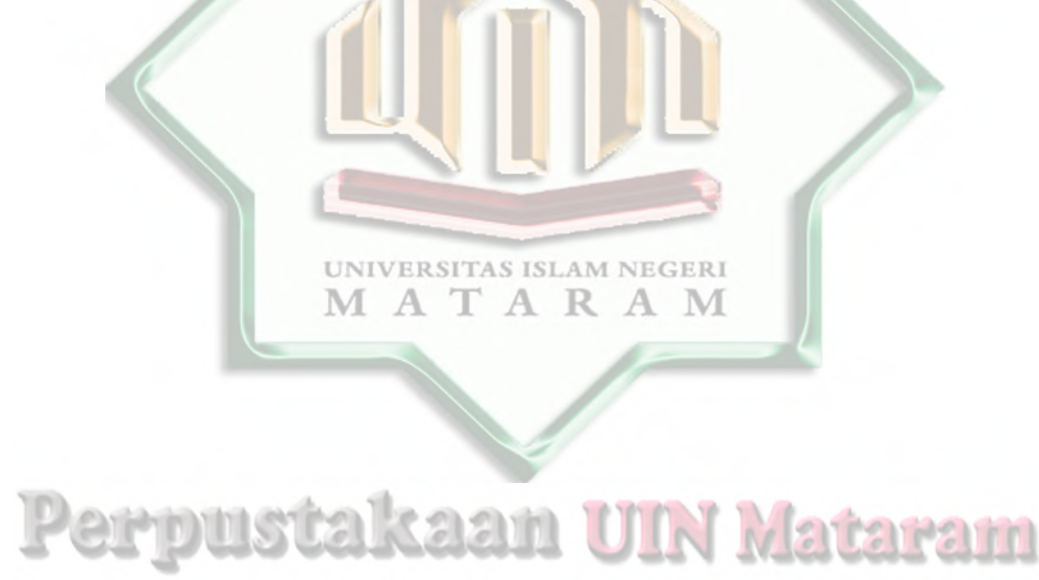

\section{Lampiran II}


Tabel 1 Persimpangan Kantor Gubenur

\begin{tabular}{|c|c|c|c|c|c|c|c|c|c|c|c|c|c|c|c|c|c|}
\hline \multirow{2}{*}{ No } & \multirow{2}{*}{ Nama } & \multicolumn{15}{|c|}{ Nomor Butir Soal } & \multirow{2}{*}{ Jumlah } \\
\hline & & 1 & 2 & 3 & 4 & 5 & 6 & 7 & 8 & 9 & 10 & 11 & 12 & 13 & 14 & 15 & \\
\hline 1 & Ardi & 3 & 2 & 3 & 2 & 4 & 4 & 3 & 1 & 4 & 3 & 3 & 4 & 3 & 3 & 4 & 46 \\
\hline 2 & Masnah & 4 & 3 & 2 & 3 & 3 & 4 & 3 & 2 & 3 & 4 & 2 & 4 & 3 & 3 & 4 & 47 \\
\hline 3 & Juandi & 3 & 3 & 2 & 3 & 3 & 4 & 3 & 2 & 4 & 3 & 2 & 4 & 2 & 3 & 4 & 45 \\
\hline 4 & kurwatun & 3 & 3 & 2 & 3 & 3 & 3 & 4 & 2 & 3 & 3 & 2 & 3 & 2 & 3 & 4 & 43 \\
\hline 5 & Maliki S & 2 & 3 & 1 & 2 & 2 & 4 & 4 & 2 & 3 & 3 & 2 & 3 & 2 & 3 & 4 & 40 \\
\hline 6 & Imam & 4 & 2 & 3 & 2 & 3 & 4 & 3 & 1 & 4 & 3 & 3 & 4 & 3 & 3 & 4 & 46 \\
\hline 7 & Kurnia J & 2 & 3 & 2 & 3 & 2 & 4 & 3 & 3 & 2 & 4 & 2 & 3 & 2 & 3 & 4 & 42 \\
\hline 8 & Suhaili & 3 & 3 & 3 & 2 & 2 & 4 & 4 & 1 & 3 & 4 & 2 & 4 & 3 & 3 & 4 & 45 \\
\hline 9 & Maisarah & 3 & 3 & 2 & 2 & 3 & 4 & 3 & 2 & 3 & 3 & 2 & 4 & 3 & 3 & 4 & 44 \\
\hline 10 & Miftahul & 3 & 2 & 3 & 2 & 4 & 4 & 3 & 1 & 4 & 3 & 3 & 4 & 3 & 3 & 4 & 46 \\
\hline 11 & Basri & 2 & 3 & 1 & 3 & 3 & 3 & 3 & 1 & 3 & 4 & 2 & 3 & 2 & 3 & 4 & 40 \\
\hline 12 & Wardatul & 3 & 2 & 1 & 3 & 3 & 4 & 3 & 2 & 2 & 3 & 2 & 3 & 2 & 3 & 4 & 40 \\
\hline 13 & Jumasih & 3 & 3 & 2 & 3 & 2 & 4 & 4 & 2 & 2 & 3 & 2 & 3 & 2 & 3 & 4 & 42 \\
\hline 14 & Rifka & 4 & 2 & 3 & 2 & 4 & 4 & 3 & 1 & 4 & 3 & 3 & 4 & 3 & 3 & 4 & 47 \\
\hline 15 & Siti aisah & 4 & 3 & 2 & 3 & 3 & 4 & 3 & 2 & 3 & 3 & 2 & 3 & 3 & 3 & 4 & 45 \\
\hline 16 & Busairi & 3 & 3 & 2 & 2 & $13 A$ & $\overline{4}$ & 4 & $M_{2}$ & 3 & 3 & 2 & 4 & 3 & 3 & 4 & 45 \\
\hline 17 & Zainul A & 2 & 3 & 1 & 2 & 3 & 4 & 4 & 2 & 2 & 3 & 2 & 4 & 2 & 3 & 4 & 41 \\
\hline 18 & Hamdani & 3 & 3 & 1 & 3 & 3 & 4 & 3 & 1 & 3 & 3 & 2 & 3 & 2 & 3 & 4 & 41 \\
\hline 19 & Doni A & 3 & 2 & 3 & 2 & 4 & 4 & 3 & 1 & 4 & 3 & 3 & 4 & 3 & 3 & 4 & 46 \\
\hline 20 & Anggun & 3 & 3 & 1 & 2 & 3 & 4 & 3 & 2 & 2 & 3 & 2 & 4 & 3 & 3 & 4 & 42 \\
\hline & Jumlah & 60 & 54 & 40 & 49 & 60 & 78 & 66 & 33 & 61 & 64 & 45 & 72 & 51 & 60 & 80 & 873 \\
\hline
\end{tabular}

Tabel 2 Persimpangan Kamboja 


\begin{tabular}{|c|c|c|c|c|c|c|c|c|c|c|c|c|c|c|c|c|c|}
\hline \multirow{2}{*}{ No } & \multirow{2}{*}{ Nama } & \multicolumn{15}{|c|}{ Nomor Butir Soal } & \multirow{2}{*}{ Jumlah } \\
\hline & & 1 & 2 & 3 & 4 & 5 & 6 & 7 & 8 & 9 & 10 & 11 & 12 & 13 & 14 & 15 & \\
\hline 1 & Atika & 3 & 3 & 2 & 2 & 3 & 3 & 4 & 2 & 3 & 3 & 2 & 3 & 2 & 3 & 4 & 42 \\
\hline 2 & Jumasir & 3 & 2 & 2 & 2 & 2 & 3 & 3 & 1 & 3 & 3 & 2 & 4 & 2 & 2 & 4 & 38 \\
\hline 3 & Burhanuddin & 4 & 2 & 2 & 2 & 3 & 4 & 4 & 2 & 3 & 2 & 1 & 3 & 3 & 3 & 4 & 42 \\
\hline 4 & Umar S & 3 & 3 & 2 & 3 & 2 & 3 & 3 & 2 & 4 & 4 & 2 & 2 & 3 & 2 & 4 & 42 \\
\hline 5 & Jumirahadi & 3 & 3 & 2 & 2 & 2 & 3 & 3 & 1 & 4 & 3 & 2 & 3 & 2 & 3 & 4 & 40 \\
\hline 6 & Manuh & 2 & 2 & 2 & 3 & 3 & 3 & 3 & 1 & 2 & 3 & 3 & 3 & 2 & 3 & 4 & 39 \\
\hline 7 & Pauzan & 3 & 3 & 1 & 2 & 3 & 4 & 3 & 2 & 2 & 4 & 2 & 4 & 3 & 3 & 4 & 43 \\
\hline 8 & Yuyun & 2 & 3 & 3 & 2 & 2 & 4 & 4 & 1 & 4 & 3 & 2 & 3 & 2 & 3 & 3 & 41 \\
\hline 9 & Angga & 2 & 3 & 1 & 2 & 2 & 2 & 3 & 2 & 3 & 3 & 2 & 3 & 2 & 2 & 3 & 35 \\
\hline 10 & Lutfi & 3 & 2 & 3 & 2 & 3 & 4 & 3 & 2 & 4 & 3 & 1 & 4 & 3 & 3 & 4 & 44 \\
\hline 11 & Suci R & 2 & 3 & 1 & 2 & 3 & 4 & 4 & 1 & 4 & 4 & 2 & 3 & 2 & 3 & 4 & 42 \\
\hline 12 & Laela W & 2 & 2 & 1 & 2 & 2 & 4 & 3 & 2 & 2 & 3 & 2 & 3 & 3 & 3 & 4 & 38 \\
\hline 13 & Rahmatullah & 3 & 3 & 3 & 2 & 2 & 3 & 3 & 1 & 3 & 3 & 1 & 4 & 3 & 3 & 4 & 41 \\
\hline 14 & Deni Irawan & 3 & 2 & 2 & 2 & 3 & 4 & 3 & 1 & 4 & 3 & 2 & 3 & 2 & 3 & 4 & 41 \\
\hline 15 & Kusmiran & 4 & 3 & 2 & 3 & 2 & 3 & 3 & 2 & 4 & 4 & 2 & 3 & 2 & 3 & 4 & 44 \\
\hline 16 & Ahmad & 2 & 3 & 2 & 2 & 3 & 4 & 4 & 1 & 3 & 3 & 2 & 3 & 3 & 3 & 3 & 41 \\
\hline 17 & Zarkasi & 2 & 3 & 1 & 2 & 2 & 4 & 4 & 2 & 2 & 3 & 2 & 4 & 3 & 3 & 4 & 41 \\
\hline 18 & Toni & 2 & 3 & $\mathrm{M}$ & 2 & 13 & 4 & 4 & 12 & 3 & 3 & 1 & 4 & 2 & 2 & 3 & 39 \\
\hline 19 & Siddikin & 3 & 2 & 2 & 2 & 3 & 4 & 3 & 2 & 4 & 2 & 1 & 3 & 2 & 3 & 4 & 40 \\
\hline 20 & Farisin & 2 & 3 & 2 & 2 & 2 & 3 & 3 & 2 & 3 & 3 & 2 & 3 & 3 & 3 & 4 & 40 \\
\hline & Jumlah & 53 & 53 & 37 & 43 & 50 & 70 & 67 & 32 & 64 & 62 & 36 & 65 & 49 & 56 & 76 & 813 \\
\hline
\end{tabular}

Tabel 3 Persimpangan Sriwijaya 


\begin{tabular}{|c|c|c|c|c|c|c|c|c|c|c|c|c|c|c|c|c|c|}
\hline \multirow{2}{*}{ No } & \multirow{2}{*}{ Nama } & \multicolumn{14}{|c|}{ Nomor Butir Soal } & \multicolumn{2}{|c|}{ Jumlah } \\
\hline & & 1 & 2 & 3 & 4 & 5 & 6 & 7 & 8 & 9 & 10 & 11 & 12 & 13 & 14 & 15 & \\
\hline 1 & Marianah & 3 & 3 & 2 & 2 & 2 & 4 & 4 & 1 & 3 & 3 & 2 & 4 & 1 & 3 & 4 & 41 \\
\hline 2 & Rohmatul A & 3 & 3 & 1 & 2 & 2 & 3 & 4 & 1 & 3 & 3 & 2 & 3 & 2 & 2 & 4 & 38 \\
\hline 3 & Jumaenah & 2 & 2 & 2 & 2 & 2 & 4 & 3 & 2 & 3 & 4 & 2 & 3 & 2 & 3 & 2 & 38 \\
\hline 4 & Doni & 3 & 3 & 1 & 2 & 3 & 4 & 3 & 1 & 3 & 3 & 2 & 4 & 2 & 2 & 4 & 40 \\
\hline 5 & Rita A & 2 & 2 & 2 & 3 & 2 & 3 & 4 & 2 & 2 & 3 & 2 & 3 & 2 & 3 & 3 & 38 \\
\hline 6 & Asnawi & 2 & 3 & 2 & 2 & 3 & 3 & 4 & 1 & 4 & 3 & 2 & 3 & 3 & 3 & 4 & 42 \\
\hline 7 & Sunardi & 3 & 3 & 2 & 2 & 3 & 4 & 3 & 1 & 3 & 4 & 2 & 3 & 3 & 3 & 4 & 43 \\
\hline 8 & Sobirin & 2 & 3 & 2 & 2 & 3 & 4 & 4 & 1 & 3 & 3 & 2 & 4 & 2 & 3 & 3 & 41 \\
\hline 9 & Umi R & 3 & 3 & 1 & 3 & 2 & 3 & 4 & 1 & 3 & 4 & 2 & 4 & 1 & 2 & 3 & 38 \\
\hline 10 & Hilmi & 3 & 3 & 2 & 2 & 2 & 3 & 3 & 1 & 3 & 3 & 2 & 3 & 2 & 3 & 4 & 40 \\
\hline 11 & Hilmatul & 2 & 3 & 2 & 2 & 2 & 4 & 3 & 2 & 3 & 2 & 2 & 3 & 3 & 2 & 4 & 40 \\
\hline 12 & Rian & 2 & 2 & 1 & 3 & 2 & 4 & 4 & 1 & 4 & 3 & 2 & 3 & 2 & 3 & 2 & 37 \\
\hline 13 & Alfian & 2 & 3 & 2 & 2 & 2 & 2 & 4 & 2 & 2 & 3 & 2 & 4 & 2 & 3 & 4 & 39 \\
\hline 14 & Warwan & 2 & 3 & 3 & 2 & 2 & 4 & 3 & 1 & 3 & 3 & 2 & 4 & 3 & 3 & 3 & 41 \\
\hline 15 & Rizalul & 3 & 3 & 2 & 2 & 3 & 3 & 3 & 1 & 4 & 4 & 2 & 3 & 2 & 3 & 4 & 42 \\
\hline 16 & Jusiah & 2 & 3 & 2 & 2 & 3 & 4 & 4 & 1 & 2 & 3 & 2 & 3 & 3 & 3 & 3 & 40 \\
\hline 17 & H. Salman & 2 & 3 & 2 & 2 & 2 & 3 & 3 & 1 & 3 & 2 & 2 & 4 & 2 & 3 & 4 & 38 \\
\hline 18 & Sartini & 3 & 2 & $1 \mathrm{M}$ & 2 & 12 & $4 R$ & 4 & 12 & 3 & 3 & 2 & 3 & 2 & 2 & 4 & 39 \\
\hline 19 & Maariah & 3 & 3 & 2 & 2 & 3 & 3 & 4 & 1 & 4 & 3 & 2 & 3 & 3 & 3 & 3 & 42 \\
\hline 20 & Zuriatun & 2 & 2 & 3 & 2 & 3 & 3 & 3 & 1 & 3 & 3 & 2 & 4 & 3 & 3 & 4 & 41 \\
\hline & Jumlah & 49 & 55 & 37 & 43 & 48 & 69 & 71 & 25 & 61 & 62 & 40 & 68 & 45 & 55 & 70 & 798 \\
\hline
\end{tabular}


Hasil Kuisioner Persimpangan Golkar

\begin{tabular}{|c|c|c|c|c|c|c|c|c|c|c|c|c|c|c|c|c|c|}
\hline \multirow{3}{*}{$\begin{array}{l}N \\
0\end{array}$} & \multirow{3}{*}{ Nama } & \multicolumn{15}{|c|}{ Nomor Butir Soal } & \multirow{3}{*}{$\underset{\mathrm{h}}{\text { Jumla }}$} \\
\hline & & & & & & & & & & & 1 & 1 & 1 & 1 & & 1 & \\
\hline & & 1 & 2 & 3 & 4 & 5 & 6 & 7 & 8 & 9 & 0 & 1 & 2 & 3 & 4 & 5 & \\
\hline 1 & paizzah & 2 & 2 & 3 & 1 & 3 & 4 & 3 & 2 & 4 & 3 & 2 & 4 & 1 & 2 & 4 & 40 \\
\hline 2 & abd. Latif & 2 & 3 & 2 & 2 & 3 & 3 & 4 & 1 & 4 & 4 & 2 & 4 & 1 & 3 & 4 & 42 \\
\hline 3 & konita & 2 & 2 & 3 & 1 & 3 & 4 & 4 & 1 & 4 & 3 & 2 & 4 & 2 & 3 & 2 & 40 \\
\hline 4 & roni ramadhan & 3 & 3 & 3 & 2 & 2 & 4 & 4 & 1 & 3 & 4 & 2 & 3 & 1 & 3 & 4 & 42 \\
\hline 5 & ahmad gozali & 2 & 2 & 2 & 3 & 3 & 4 & 4 & 1 & 3 & 4 & 2 & 4 & 2 & 3 & 4 & 43 \\
\hline 6 & erlangga & 2 & 3 & 2 & 3 & 2 & 4 & 4 & 2 & 4 & 4 & 2 & 4 & 1 & 2 & 4 & 43 \\
\hline 7 & yuli & 2 & 3 & 2 & 2 & 3 & 4 & 4 & 1 & 4 & 4 & 2 & 3 & 3 & 2 & 4 & 43 \\
\hline 8 & safa & 2 & 2 & 4 & 3 & 3 & 3 & 4 & 2 & 4 & 3 & 2 & 3 & 2 & 3 & 4 & 44 \\
\hline 9 & rina mariana & 2 & 3 & 2 & 3 & 3 & 3 & 4 & 1 & 4 & 3 & 2 & 4 & 3 & 3 & 3 & 43 \\
\hline 10 & riki wijaya & 3 & 2 & 1 & 2 & 2 & 4 & 3 & 1 & 4 & 4 & 2 & 4 & 2 & 3 & 4 & 41 \\
\hline 11 & megawati & 3 & 3 & 2 & 2 & 3 & 4 & 4 & 1 & 3 & 4 & 2 & 4 & 2 & 3 & 4 & 44 \\
\hline 12 & arman & 2 & 3 & 3 & 1 & 3 & 4 & 4 & 1 & 4 & 4 & 2 & 3 & 1 & 2 & 3 & 40 \\
\hline 13 & junita & 2 & 3 & 4 & 2 & 2 & 3 & 3 & 2 & 4 & 3 & 2 & 3 & 2 & 3 & 4 & 42 \\
\hline 14 & kahirul & 3 & 3 & 3 & 2 & 3 & 4 & 4 & 1 & 4 & 4 & 2 & 4 & 2 & 3 & 3 & 45 \\
\hline 15 & samlar & 2 & 2 & 2 & 1 & 3 & 3 & 4 & 2 & 3 & 4 & 2 & 4 & 3 & 3 & 4 & 42 \\
\hline 16 & hayatun & 2 & 3 & 3 & 2 & 2 & 2 & 3 & 1 & 4 & 4 & 2 & 3 & 2 & 3 & 3 & 39 \\
\hline 17 & endang & 2 & 3 & 2 & 2 & 3 & 2 & 4 & 2 & 4 & 3 & 2 & 4 & 2 & 2 & 2 & 39 \\
\hline 18 & agus & 3 & 2 & 4 & 2 & 3 & 4 & 4 & 1 & 3 & 3 & 2 & 4 & 3 & 3 & 4 & 45 \\
\hline 19 & mutaman & 3 & 3 & 3 & 2 & 3 & 4 & 3 & 1 & 3 & 4 & 2 & 4 & 3 & 3 & 4 & 45 \\
\hline 20 & hajidin & 2 & 3 & 3 & 1 & 2 & 3 & 4 & 1 & 4 & 4 & 2 & 3 & 2 & 3 & 4 & 41 \\
\hline & & 4 & 5 & 5 & 3 & 5 & 7 & 7 & 2 & 7 & 7 & 4 & 7 & 4 & 5 & 7 & \\
\hline & jumlah & 6 & 3 & 3 & 9 & 4 & 0 & 5 & 6 & 4 & 3 & 0 & 3 & 0 & 5 & 2 & 843 \\
\hline
\end{tabular}


Lampiran II

Hasil Kuisioner Persimpangan STMIK

\begin{tabular}{|c|c|c|c|c|c|c|c|c|c|c|c|c|c|c|c|c|c|}
\hline \multirow{2}{*}{$\begin{array}{c}\text { N } \\
\text { o }\end{array}$} & Nama & & \multicolumn{10}{|c|}{} & & & & & \multicolumn{10}{|c|}{ Jumla } \\
\hline 1 & nurlina & 3 & 3 & 2 & 3 & 3 & 3 & 4 & 1 & 4 & 3 & 2 & 3 & 1 & 3 & 3 & 41 \\
\hline 2 & liza & 2 & 3 & 3 & 2 & 3 & 4 & 3 & 2 & 3 & 3 & 3 & 3 & 2 & 2 & 4 & 42 \\
\hline 3 & jazrul & 2 & 2 & 3 & 3 & 4 & 3 & 3 & 1 & 3 & 3 & 1 & 4 & 2 & 2 & 3 & 39 \\
\hline 4 & pahmi & 1 & 3 & 3 & 2 & 3 & 4 & 4 & 1 & 2 & 2 & 2 & 3 & 2 & 3 & 3 & 38 \\
\hline 5 & saproni & 2 & 3 & 3 & 3 & 3 & 3 & 4 & 2 & 4 & 3 & 1 & 3 & 2 & 3 & 4 & 43 \\
\hline 6 & efendi & 3 & 3 & 3 & 3 & 2 & 2 & 3 & 2 & 2 & 2 & 2 & 4 & 3 & 3 & 4 & 41 \\
\hline 7 & harfan & 2 & 3 & 2 & 1 & 4 & 4 & 4 & 2 & 4 & 4 & 2 & 3 & 3 & 2 & 2 & 42 \\
\hline 8 & samsul hadi & 3 & 2 & 3 & 2 & 3 & 3 & 4 & 1 & 4 & 2 & 1 & 3 & 3 & 2 & 4 & 40 \\
\hline 9 & maing & 1 & 2 & 3 & 2 & 2 & 2 & 4 & 1 & 3 & 4 & 2 & 3 & 3 & 3 & 3 & 38 \\
\hline 10 & aziz ismail & 3 & 2 & 2 & 2 & 2 & 2 & 2 & 1 & 3 & 3 & 2 & 4 & 2 & 3 & 4 & 37 \\
\hline 11 & lina & 1 & 3 & 2 & 2 & 3 & 3 & 4 & 2 & 4 & 3 & 2 & 3 & 2 & 3 & 3 & 40 \\
\hline 12 & mislaah & 2 & 3 & 1 & 1 & 2 & 4 & 3 & 2 & 4 & 4 & 3 & 3 & 1 & 3 & 3 & 39 \\
\hline 13 & maisarah & 2 & 2 & 2 & 1 & 3 & 3 & 4 & 1 & 4 & 3 & 2 & 4 & 3 & 3 & 4 & 41 \\
\hline 14 & lisa haryani & 1 & 3 & 3 & 2 & 2 & 3 & 4 & 1 & 3 & 3 & 1 & 3 & 2 & 2 & 3 & 36 \\
\hline 15 & bq. Febri & 2 & 3 & 3 & 2 & 2 & 3 & 3 & 2 & 4 & 3 & 1 & 3 & 3 & 3 & 4 & 41 \\
\hline 16 & samaratul & 2 & 3 & 3 & 2 & 3 & 4 & 3 & 1 & 3 & 4 & 2 & 3 & 3 & 3 & 4 & 43 \\
\hline 17 & yunisara & 3 & 3 & 3 & 2 & 3 & 4 & 2 & 1 & 4 & 3 & 2 & 3 & 2 & 3 & 2 & 40 \\
\hline 18 & yasir arafat & 3 & 2 & 1 & 1 & 2 & 3 & 3 & 1 & 4 & 3 & 1 & 4 & 3 & 3 & 3 & 37 \\
\hline 19 & rajul & 2 & 2 & 1 & 2 & 3 & 3 & 4 & 2 & 4 & 4 & 2 & 3 & 2 & 3 & 3 & 40 \\
\hline 20 & hilwahyuni & 2 & 3 & 3 & 2 & 2 & 4 & 4 & 1 & 3 & 3 & 1 & 4 & 1 & 3 & 3 & 39 \\
\hline & & 4 & 5 & 4 & 4 & 5 & 6 & 6 & 2 & 6 & 6 & 3 & 6 & 4 & 5 & 6 & \\
\hline & jumlah & 2 & 3 & 9 & 0 & 4 & 4 & 9 & 8 & 9 & 2 & 5 & 6 & 5 & 5 & 6 & 797 \\
\hline
\end{tabular}


Hasil Kuisioner Persimpangan Yaoya

\begin{tabular}{|c|c|c|c|c|c|c|c|c|c|c|c|c|c|c|c|c|c|}
\hline \multirow{3}{*}{$\begin{array}{l}N \\
0\end{array}$} & \multirow{3}{*}{ Nama } & \multicolumn{15}{|c|}{ Nomor Butir Soal } & \multirow{3}{*}{$\underset{\mathrm{h}}{\text { Jumla }}$} \\
\hline & & & & & & & & & & & & 1 & 1 & 1 & 1 & & \\
\hline & & 1 & 2 & 3 & 4 & 5 & 6 & 7 & 8 & 9 & 0 & 1 & 2 & 3 & 4 & 5 & \\
\hline 1 & afif & 3 & 2 & 2 & 3 & 4 & 4 & 4 & 3 & 4 & 3 & 2 & 3 & 2 & 3 & 4 & 46 \\
\hline 2 & mailani & 3 & 3 & 2 & 3 & 3 & 4 & 4 & 1 & 4 & 3 & 2 & 3 & 1 & 3 & 4 & 43 \\
\hline 3 & bq. Siti risa & 3 & 2 & 2 & 3 & 3 & 4 & 4 & 1 & 4 & 2 & 2 & 2 & 1 & 2 & 3 & 38 \\
\hline 4 & januarti & 1 & 2 & 3 & 3 & 4 & 3 & 3 & 1 & 3 & 3 & 2 & 3 & 2 & 3 & 3 & 39 \\
\hline 5 & rizki & 2 & 3 & 2 & 3 & 3 & 4 & 3 & 2 & 4 & 3 & 2 & 3 & 2 & 3 & 4 & 43 \\
\hline 6 & azlina & 1 & 2 & 3 & 2 & 3 & 3 & 4 & 2 & 3 & 2 & 1 & 2 & 2 & 3 & 4 & 37 \\
\hline 7 & m. toha & 1 & 3 & 3 & 3 & 4 & 3 & 4 & 2 & 3 & 3 & 3 & 4 & 3 & 3 & 2 & 44 \\
\hline 8 & suandi & 2 & 3 & 2 & 2 & 2 & 2 & 3 & 2 & 4 & 4 & 2 & 3 & 2 & 2 & 4 & 39 \\
\hline 9 & zulfa & 3 & 2 & 3 & 2 & 3 & 3 & 3 & 1 & 4 & 3 & 2 & 4 & 3 & 3 & 3 & 42 \\
\hline 10 & zulul & 3 & 3 & 2 & 2 & 3 & 2 & 4 & 2 & 4 & 4 & 2 & 2 & 3 & 2 & 3 & 41 \\
\hline 11 & ningsih & 2 & 3 & 3 & 3 & 2 & 4 & 4 & 1 & 4 & 2 & 2 & 3 & 3 & 3 & 3 & 42 \\
\hline 12 & sahrulaini & 2 & 3 & 2 & 2 & 2 & 4 & 4 & 1 & 4 & 4 & 2 & 3 & 1 & 3 & 4 & 41 \\
\hline 13 & jumadil & 2 & 3 & 2 & 2 & 2 & 3 & 4 & 1 & 3 & 3 & 1 & 4 & 1 & 3 & 3 & 37 \\
\hline 14 & awaluddin & 1 & 3 & 2 & 3 & 3 & 4 & 2 & 2 & 4 & 3 & 2 & 3 & 2 & 2 & 4 & 40 \\
\hline 15 & muis & 2 & 3 & 3 & 3 & 3 & 3 & 4 & 2 & 2 & 3 & 2 & 4 & 2 & 3 & 4 & 43 \\
\hline 16 & sakinah & 2 & 2 & 2 & 2 & 3 & 4 & 3 & 2 & 3 & 3 & 1 & 3 & 3 & 3 & 3 & 39 \\
\hline 17 & harfinna & 2 & 3 & 3 & 2 & 2 & 4 & 4 & 1 & 4 & 3 & 1 & 4 & 3 & 3 & 4 & 43 \\
\hline 18 & mariana & 3 & $3^{1}$ & 3 & 3 & 2 & 3 & 3 & 2 & 31 & 4 & 2 & 3 & 3 & 2 & 4 & 43 \\
\hline 19 & asna & 3 & $\sqrt{3}$ & 2 & 1 & 3 & 3 & 4 & 1 & 3 & 3 & 2 & 3 & 2 & 3 & 3 & 39 \\
\hline 20 & nita komala & 2 & 3 & 2 & 2 & 3 & 4 & 3 & 1 & 4 & 4 & 1 & 3 & 3 & 3 & 3 & 41 \\
\hline & & 4 & 5 & 4 & 4 & 5 & 6 & 7 & 3 & 7 & 6 & 3 & 6 & 4 & 5 & 6 & \\
\hline & jumlah & 3 & 4 & 8 & 9 & 7 & 8 & 1 & 1 & 1 & 2 & 6 & 2 & 4 & 5 & 9 & 820 \\
\hline
\end{tabular}


Hasil Kuisioner Persimpangan Pagutan

\begin{tabular}{|c|c|c|c|c|c|c|c|c|c|c|c|c|c|c|c|c|c|}
\hline \multirow{2}{*}{$\begin{array}{l}N \\
0\end{array}$} & \multirow[b]{2}{*}{ Nama } & \multicolumn{15}{|c|}{ Nomor Butir Soal } & \multirow{2}{*}{$\begin{array}{c}\text { Jumla } \\
\mathrm{h}\end{array}$} \\
\hline & & 1 & 2 & 3 & 4 & 5 & 6 & 7 & 8 & 9 & $\begin{array}{l}1 \\
0\end{array}$ & $\begin{array}{l}1 \\
1\end{array}$ & $\begin{array}{l}1 \\
2\end{array}$ & $\begin{array}{l}1 \\
3 \\
\end{array}$ & $\begin{array}{l}1 \\
4\end{array}$ & $\begin{array}{l}1 \\
5\end{array}$ & \\
\hline 1 & nila & 3 & 3 & 7 & 1 & 4 & 3 & 4 & 1 & 4 & 3 & 2 & 3 & 3 & 3 & 4 & 43 \\
\hline 2 & masitah & 2 & 3 & 3 & 1 & 4 & 4 & 3 & 2 & 4 & 3 & 1 & 2 & 2 & 2 & 3 & 39 \\
\hline 3 & roni sarif & 3 & 2 & 4 & 1 & 4 & 3 & 4 & 3 & 3 & 3 & 2 & 3 & 2 & 2 & 4 & +3 \\
\hline 4 & jumra & 2 & 3 & 4 & 1 & 2 & 2 & 4 & 1 & 3 & 2 & 1 & 3 & 2 & 2 & 3 & 35 \\
\hline 5 & wah & 2 & 2 & -2 & 2 & 3 & 4 & 3 & 1 & 4 & 2 & 2 & 3 & 2 & 3 & 4 & 39 \\
\hline 6 & sriwahyuni & 3 & 2 & 3 & 2 & 3 & 4. & 4 & II & 4 & 3 & 2 & 3 & 1 & $\therefore$ & 4 & 42 \\
\hline 7 & biduri & 2 & 3 & 3 & 2 & 2 & 4 & 3 & 1 & 4 & 2 & 1 & 3 & 2 & 2 & 4 & 38 \\
\hline 8 & surys & 2 & 2 & 4 & 1 & 2 & 4 & 4 & 2 & 3 & 2 & 2 & 3 & 2 & 2 & 4 & 39 \\
\hline 9 & gigih & 2 & 3 & 3 & 2 & 3 & 3 & 4 & 2 & 1 & 3 & 2 & 2 & $?$ & $i$ & $\downarrow$ & 43 \\
\hline 10 & atan hizadain & 2 & 2 & 3 & 2 & 4 & 2 & 4 & 1 & 3 & 3 & 2 & 3 & 3 & 3 & 4 & +1 \\
\hline 11 & harta & 2 & 3. & 2 & 1 & 4 & 3 & 3 & 2 & 4 & 2 & 2 & 2 & 2 & 3 & 3 & 38 \\
\hline 12 & h & 3 & 2 & 2 & 1 & 3 & 4 & 4 & 1 & 4 & 3 & ? & 4 & $!$ & 3 & 3 & 40 \\
\hline 13 & laili & 2 & 3 & 2 & 2 & 3 & 4 & 1 & 1 & 4 & 4 & 2 & 3 & 3 & 2 & 1 & 43 \\
\hline 14 & warni & 2 & 3 & 3 & 2 & 3 & 4 & 4 & $1 !$ & 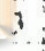 & 2 & 1 & 2 & $?$ & 3 & 3 & 38 \\
\hline 15 & sholatiah & 2 & 3 & 3 & 1 & 4 & 4 & 3 & $\therefore$ & 4 & 3 & 2 & 4 & 1 & 3 & 2 & 41 \\
\hline 16 & raudaul & 3 & 3 & 4 & 2 & 2 & 3 & 3 & $?$ & 4 & 4 & , & 3 & 2 & $\therefore$ & 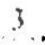 & 43 \\
\hline 17 & susanti & 3 & 3 & 3 & 2 & 3 & 3 & 4 & 2 & 3 & 3 & 7 & 3 & 2 & 3 & 1 & 43 \\
\hline 18 & burhan & 3 & 2 & 4 & 1 & 3 & \pm & \pm & 11 & 4 & 3 & 1 & 4 & 1 & 2 & \& & $\$ 1$ \\
\hline 19 & jamal & 2 & 2 & 2 & 2 & 3 & $t$ & 3 & 1 & 4 & 4 & 2 & 3 & 3 & 3 & 3 & +1 \\
\hline 20 & lalu ppandi & 2 & 3 & 3 & 2 & 2 & 4 & 3 & 1 & 4 & 2 & 2 & 3 & 2 & 3 & 4 & $4 !$ \\
\hline & & 4 & 5 & 5 & 3 & 6 & 7 & 7 & 2 & 7 & 5 & 3 & 5 & 4 & 5 & 7 & \\
\hline & jumlah & 7 & 2 & 9 & 1 & 1 & 0 & 2 & 9 & 4 & 6 & 5 & 9 & 1 & 3 & 1 . & 810 \\
\hline
\end{tabular}


DOKUMENTASI PENELITIAN

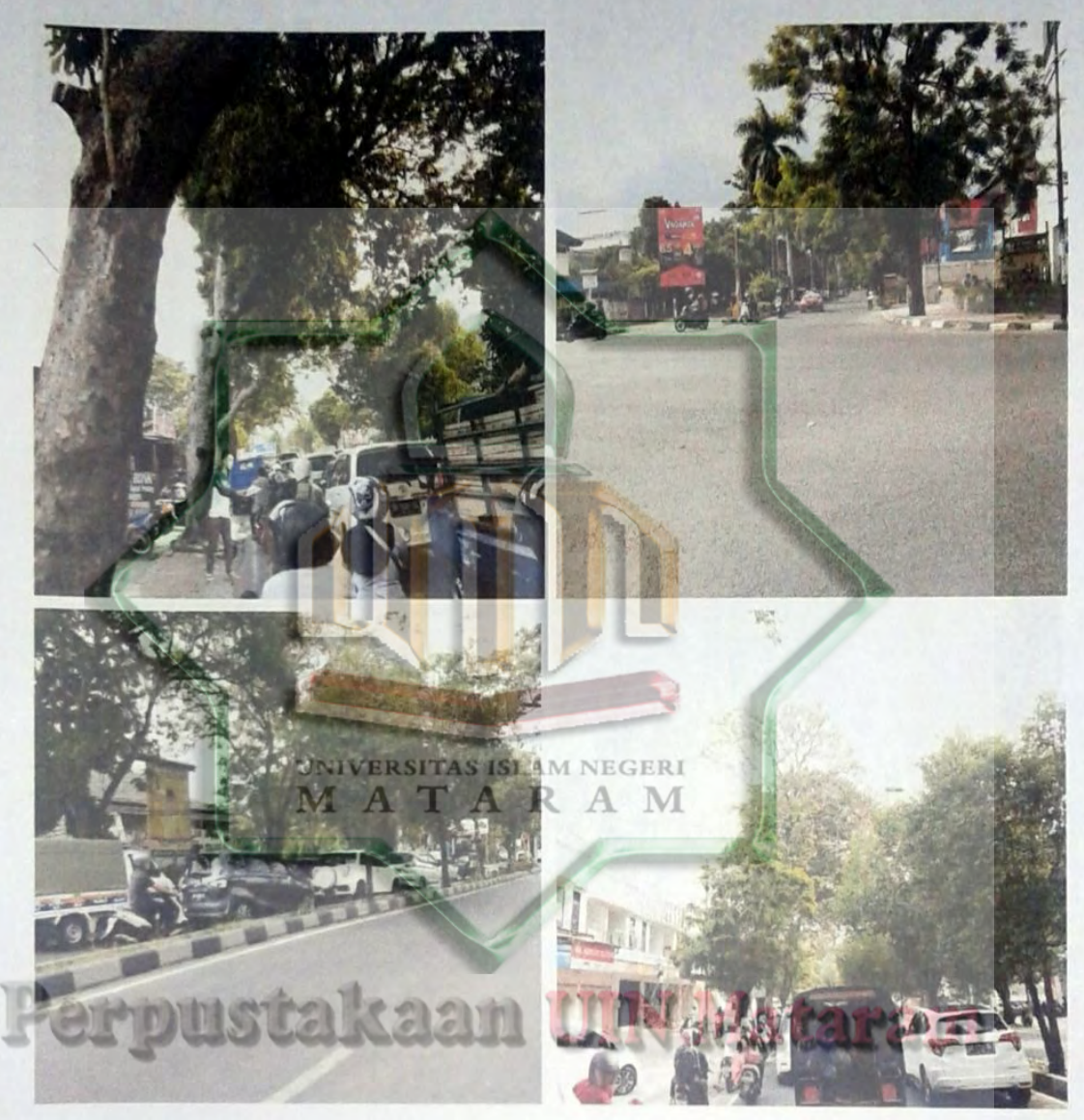




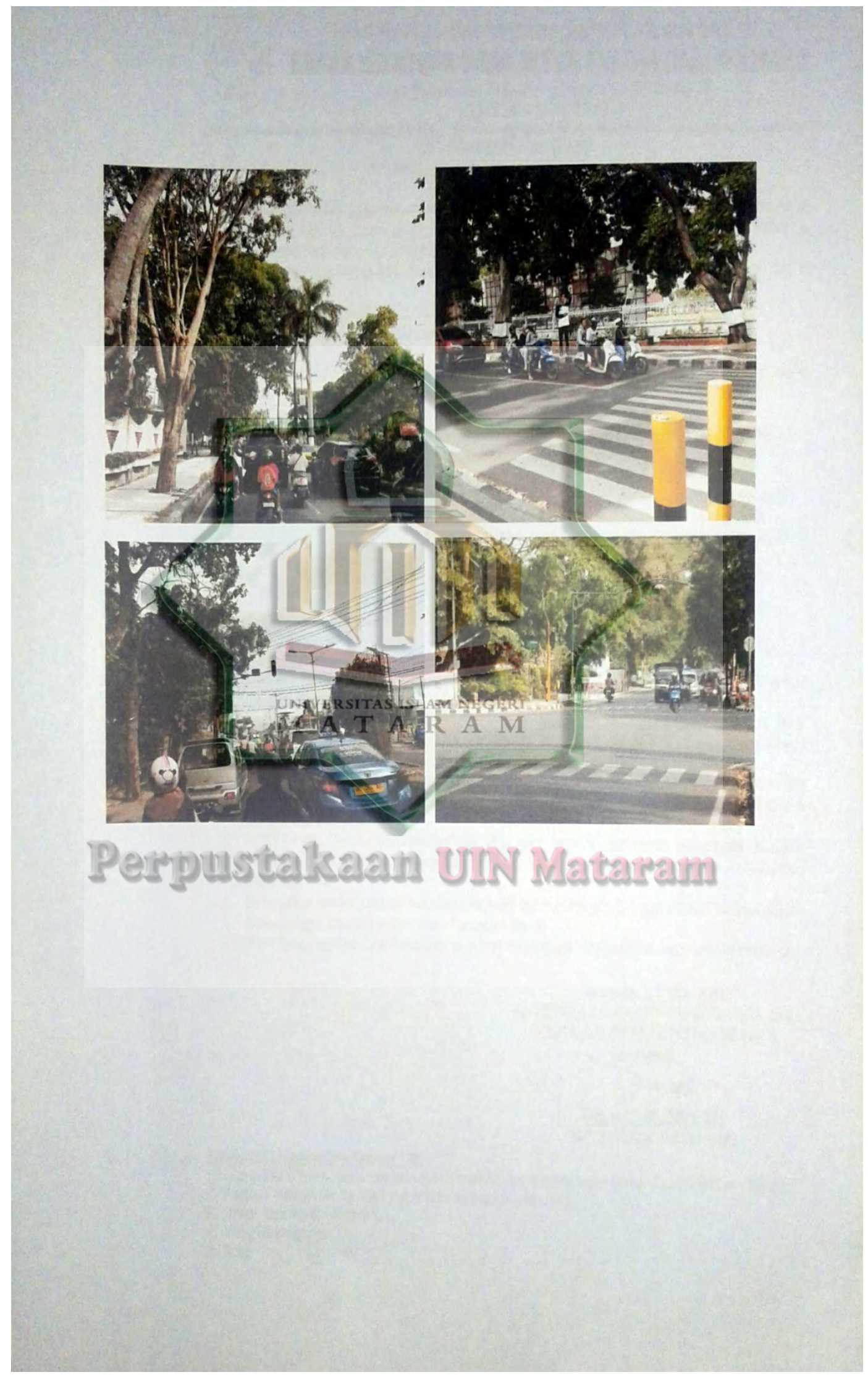




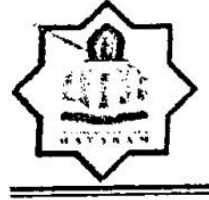

Mataram, 17 Mei 2018
KEMENTERIAN AGAMA

UNIVERSITAS ISLAM NEGERI MATARAM

FAKULTAS TARBIYAH DAN KEGURUAN

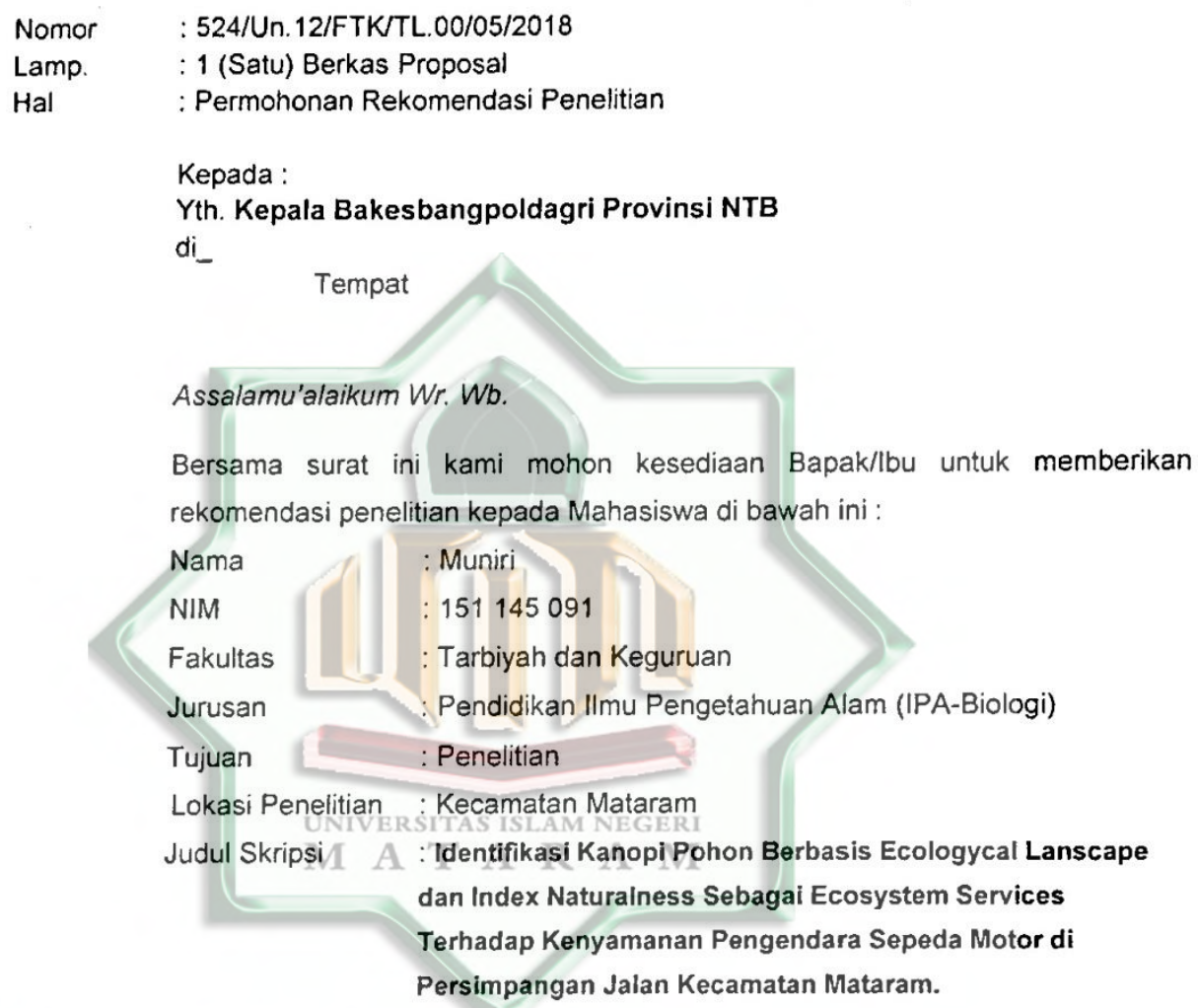

Rekomendasi tersebut digunakan untuk mendapatkan data yang diperlukan dalam penyusunan skripsi.

Demikian surat pengantar ini kami buat, atas kerjasama Bapak/lbu kami sampaikan terima kasih.

Wassalamu'alaikum Wr. Wb.

An. Dekan

Wakil Dekan Bidang Akademik

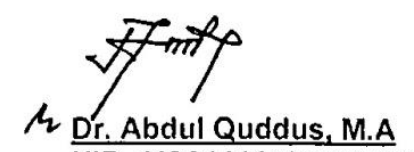

NIP. 197811112005011009

Tembusan :

1. Arsip Akademik FTK 


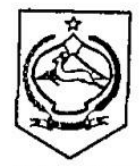

PEMERINTAH PROVINSI NUSA TENGGARA BARAT BADAH IESATUAH BAHGSA DAH POLITIK DALAM HEGERI

Jalan Pendidikan Nomor 2 Mataram Kode Pos.83125 Tlp./ Fax. (0370) 7505330

REKOMENDASI PENELITIAN

NOMOR : $070 / \mathrm{si8} / \mathrm{V} / \mathrm{R} / \mathrm{BKBPDN} / 2018$

1. Dasar

a. Peraturan Menteri Dalam Negeri Republik Indonesia Nomor 7 Tahun 2014 tentang Perubahan Atas Peraturan Menteri Dalam Negeri Republik Indonesia Nomor 64 Tahun 2011 tentang Pedoman Penerbitan Rekomendasi Penelitian.

b. Surat dari Wakil Dekan Bid. Akademik Fakultas Tartiyah dan Kegunan Universitas Islam Negeri Mataram.

Nomor : 524NN.12/FTKTL.00/05/2018,Tanggal 17 Mei 2018

Perihal : Permohonan Rekomendasi Penelitian.

2. Menimbang:

Setelah mempelajari Proposal Survei/Rencana Kegiatan Penelitian yang diajukan, maka dapat diberikan Rekomendasi Penelitian Kepada :

Nama MUNIR

Alamat : Desa Pene Kec.Jerowaru Kab. Lombok Timur. No. Telp. 082339779790 NNo.

Identitas. 5203203112950172

Pekerjaan : Mahasiswa

Bidang/Judul : IDENTIFIKASI KANOPIPOHON BERBASIS ECOLOGYCAL LANSCAPE DAN INDEX NATUARALNESS SEBAGAI ECOSYSTEM SERVICES TERHADAP KENYAMANAN PENGENDARA SEPEDA MOTOR DI PERSIMPANGAN JALAN

Lokasi KECAMATAN MATARAM

Jumlah Peserta : 1 (satu) Orang.

Lamanya : Mei-Juni 2018

Status Penelitian : Baru.

3. Hal-hal yang harus ditaati oleh Peneliti:

a. Sebelum melakukan Kegiatan Penelitian agar melaporkan kedatangan Kepada BupatiNalikota atau Pejabat yang ditunjuk; V ERSITAS ISL A M NEGFRi

b. Penelitian yang dilakukan tharus sesuai dengan judul beserta data dan berkas pada Surat Permohonan dan apabila melanggar ketentuan, maka Rekomendasi Penelitian akan dicabut sementara dan menghentikan segala kegiatan penelitian;

c. Peneliti harus mentaatj ketentuan Perundang-Undangan, norma-norma dan adat istiadat yang berlaku dan penelitian yang dilakukan tidak menimbulkan keresahan di masyarakat, disintegrasi Bangsa atau keutuhan NKRl;

d. Apabila masa berlaku Rekomendasi Penelitjan telah berakhir, sedangkan pelaksanaan Kegiatan Penelitian tersebut belum selesai maka Peneliti hans mengajukan perpanjangan Rekomendasi Penelitian:

e. Melaporkan hasil Kegiatan Penelitian kepada Gubernur Nusa Tenggara Barat melalui Kepala Bakesbangpoldagri Provinsi Nusa Tenggara Barat.

Demikian Surat Rekomendasi Penelitian ini di buat untuk dapat dipergunakan sebagaimana mestinya.

\footnotetext{
Mataram, 2s Mei 2018

An. KEPALA BADAN KESATUAN BANGSA DAN POLITIK DALAM NEGERI PROVINSI NTB

Sekretaris,<smiles>CC1NC(=O)C1C</smiles>

Drs. KATARUDDIN, MH

NIP. 196112311985031175

Tembusan disampaikan Kepada Yth:

1. Kepala Badan Perencanaan Pembangunan, Penelitian dan Pengembangan Daerah Provinsi NTB di - Mataram;

2. Wallikota Mataram Cq. Ka. Kesbangpol Kota Mataram di - Mataram;

3. Camat Mataram di - Mataram;

4. Yang Bersangkutan.:

5. Arsip.
} 